\title{
Abolishing Obsolete Crown Prerogatives Relating to: Martial Law, Conscription and Billeting
}

\author{
Graham S McBain ${ }^{1}$ \\ ${ }^{1}$ Solicitor. MA (Cantab), LLB (Cantab), LLM (Harv). Open Scholar, Peterhouse, Cambridge. Fulbright Scholar, \\ Harvard Law School. \\ Correspondence: Graham S McBain, 21 Millmead Terrace, Guildford, Surrey GU2 4AT, UK. Email: \\ gsmcbain@aol.com
}

Received: August 1, 2012 Accepted: August 23, 2012 Online Published: October 26, 2012

doi:10.5539/ilr.v1n1p13

URL: http://dx.doi.org/10.5539/ilr.v1n1p13

\begin{abstract}
This article indicates that there are various rights, or privileges, of the Crown (so - called 'Crown prerogatives') which still exist under English law and which are at variance with modern society and human rights. Indeed, one would assert the Crown prerogative is the biggest impediment in English based legal systems to an extension of human rights at present, since it is so ample in scope and yet so indeterminate in nature.

This article argues that martial law - that is, the right of the Crown to apply military law to civilians (which often resulted in their summary trial and execution in past rebellions) - should be abolished. It is unnecessary and contrary to modern human rights. Also abolished should be the right of the Crown to billet members of the armed forces on the public - now governed by legislation. Finally, the Crown prerogative to forcibly conscript able-bodied male subjects into the army and navy should be abolished. It was replaced by legislation during World War I and II since it was thought to be too uncertain, legally.

In conclusion, if these Crown prerogatives were abolished throughout the Commonwealth it would remove much old law and help human rights. It would also allow legislation enacted by Parliament to cover the field, as and when required in the case of martial law.
\end{abstract}

Keywords: martial law, conscription, impressment, billeting

\section{Introduction}

A previous article in the Nottingham Law Journal advocated the abolition of various obsolete Crown prerogatives relating to the military. ${ }^{1}$ As noted in that article, a vast number of decisions are taken in the name of that mysterious - and amorphous entity - 'the Crown', although the Queen herself, today, only retains a ceremonial role and she is not held accountable for such decisions. Thus, such decisions often result in a distinct lack of Parliamentary oversight and control. The House of Commons, Public Select Committee, in 2004 - in a report entitled 'Taming the Prerogative: Strengthening Ministerial Accountability to Parliament' ${ }^{2}$ - expressed concern that many Crown prerogatives had come to be delegated by the sovereign to ministers and that they could be exercised without Parliamentary approval or scrutiny. The report also indicated that various Crown prerogatives were in need of reform and that others were obsolete. ${ }^{3}$ This article argued for the abolition of prerogatives of the Crown to:

- impress subjects for the navy (no longer applied after 1814);

- $\quad$ issue letters of marque (obsolete after 1856$) ;{ }^{4}$

- issue letters of safe conduct (obsolete c. 1836);

- prohibit subjects from leaving the realm (in abeyance pre-1688), ${ }^{5}$

\footnotetext{
${ }^{1}$ McBain (2011a), vol 20, 14-37.

${ }^{2}$ House of Commons (2004).

${ }^{3}$ A draft Bill contained in the report which is entitled Ministers of the Crown (Executive Powers) Bill, s 4 expressly refers to: 'The desirability that any obsolete, unnecessary or inappropriate [Crown] powers be abrogated.'

${ }^{4}$ For some comments on the early law of reprisal, see Bruce (1717), 16-20. For the recalling of letters of marque issued by Elizabeth I (1558-1603) and by James I (1603-25) see Hume (1884), vol 4, 398-9. See also Hale (1736), vol 1, 162-3.
} 
- $\quad$ order subjects to return to the realm (in abeyance pre-1688); ${ }^{6}$

- dig for saltpetre in order to make gunpowder (obsolete by the $19^{\text {th }}$ century, at the latest).

The purpose of this article is to consider some further obsolete Crown prerogatives and to argue for their abolition. These are Crown prerogatives to:

- impose martial law;

- conscript (impress) subjects into the army and navy;

- billet members of the armed forces on the general public.

There are few legal texts dedicated to the Crown prerogatives. ${ }^{7}$ The most useful are:

- Staunford, Exposition of the King's Prerogative (1607); ${ }^{8}$

- Hale, The Prerogatives of the King (written c. 1640 's) $;^{9}$

- J Chitty Jun, A Treatise of the Law of the Prerogatives of the Crown (1820); ${ }^{10}$

- Coke, Institutes of the Laws of England (1628-41); ${ }^{11}$

- Blackstone, Commentaries on the Laws of England (1765-9); ${ }^{12}$

- Halsbury, Laws of England. ${ }^{13}$

Although the Abridgments - both major ${ }^{14}$ and minor ${ }^{15}$ - contain material on the Crown prerogatives, they add little to these texts. Finally, there are also modern texts on constitutional law ${ }^{16}$ and history ${ }^{17}$ - as well as some general texts concerning Crown prerogatives which are of incidental interest. ${ }^{18}$

Martial Law ${ }^{19}$

What martial law is under English law and - indeed, whether it even exists - is open to dispute. Martial law has been interpreted to mean, at least, four things and - quite possibly - more. Thus, it can refer to:

a. the system of military law imposed by the Crown which regulated the discipline of the armed forces, prior to legislation being introduced to govern the military after the Glorious Revolution of $1688 ;{ }^{20}$

\footnotetext{
${ }^{5}$ See also an authority not cited in my earlier article (n 1). Forsyth (1969), 164 (a legal opinion of a law officer referred, in 1788, to the practice of prohibiting, by proclamation, naval personnel from going abroad in order to enter a foreign naval service when the state of Europe [ie. the power of France] would render it dangerous to weaken the strength of the British nation. The grounds for the exercise of the Crown prerogative to prohibit naval personnel from going abroad in that opinion no longer apply). See also Hallam (1897), vol 2, 58 (a proclamation of Charles (1625-49) as late as 1638 ordered that no one might leave for New England (in the USA) without a licence). For an attempt c. 1530 to make it treason to depart from the realm contemptuously (if owing allegiance) and taking an oath to a foreign potentate renouncing allegiance to the English king, see Bellamy (1979), 25.

${ }^{6}$ It was accepted, by 1718, that, in practice, there was little the Government could do in order to force a subject to return from abroad. See Forsyth, n 5, 164. In 1718, the Solicitor General (Sir William Thompson) stated 'As to those already abroad, if they are required by proclamation to return home, and do not obey, I do not know of any method of getting at them by any process abroad.'

${ }^{7}$ Earlier texts are listed in Sweet \& Maxwell (1955).

${ }^{8}$ Staunford (1607).

${ }^{9}$ Hale (1976). See also Brecknock (1764).

${ }^{10}$ Chitty (1820).

${ }^{11}$ Coke (1824).

${ }^{12}$ Blackstone (1765-9)

${ }^{13}$ Halsbury. See alsoHalsbury (Statutes).

${ }^{14}$ Statham (c. 1495), Fitzherbert (1577), Brooke (1586), Rolle (1688).

${ }^{15}$ Hughes (1660-3), Sheppard (1675), Nelson (1725-6), Bacon (1798), Viner (1741-57), Comyns (1822), Lilley (1765). Viner has been reprinted by the Law Book Exchange, with word search.

${ }^{16}$ Barendt (1998), Bradley \& Ewing (2006), De Smith \& Brazier (1998), Dicey (1948), Heuston (1964), Phillips \& Jackson (2001), Jennings (1959), Marshall (1971).

${ }^{17}$ Hallam, n 5; Jolliffe (1948), Maitland (1963), Stubbs (1874), Taswell-Langmead (1960), Wilkinson (1958).

${ }^{18}$ Allen (1849), McGlynn (2003), Wormuth (1939).

${ }^{19}$ For a list of texts on early military law, see Sweet \& Maxwell, n 7. See also Clode (1869), Scott (1968), Finlason (1867), Finlason (1866), Clark \& McCoy (2000), Capua (1977), Fairman (1943), Gross \& Aolain (2006), Dennison (1974), Bowman (1916). See also Stephen (1883), vol 1, 207-16. However, care needs to be taken with some of the observations of Stephen. His review of the source material is scant and some of his observations are too general. Care also needs to be taken in respect of Finlason, who held very pronounced, conservative, views. See also Holdsworth (1902), Earle Richards (1902), Dodd (1902) and Pollock (1902). See also Bellamy, n 5, App.

${ }^{20}$ The Oxford English Dictionary (OED)(definition of martial law), 'Formerly sometimes applied to what is now called 'military law'. viz the body of enactments and rules for the government of the army; an enactment or rule forming part of this.' Also, 'In early examples the adj[ective]
} 
b. the application of military law (and military courts) to civilians during peacetime; ${ }^{21}$

c. the application of military law (and military courts) to civilians during: (i) riots or rebellion; or (ii) war. ${ }^{22}$ This concept of martial law is often confused with other Crown prerogatives; viz. its power to act in the case of emergency and its power to maintain the peace. ${ }^{23}$ While these may include using the armed forces to quell riots and rebellions, they do not, thereby, subject civilians to military law and, thus, comprise martial law;

d. where the country is run by a military government (junta) and many civil rights are suspended; ${ }^{24}$

It may be noted - at the outset:

- That (a) has now been wholly superceded by legislation governing the armed forces. Thus, martial law is simply an archaic reference to military law;

- In the case of (b), the Petition of Right 1627, section 8 makes illegal subjects being governed by military (martial) law during peacetime, ${ }^{25}$

- In the case of (c), riots and rebellions would almost certainly be treated as being in peacetime today and in the case of war time - the Crown prerogative to declare martial law is no longer required and should no longer be used. In a modern democracy, it should be the responsibility of Parliament alone to enact legislation imposing military law on civilians in any exceptional situation where this might be required since it is such a severe curtailment of human rights;

- In the case of (d), this has never occurred, as such, in England throughout its long history. Further, it is not ' $l a w$ ' - it is rule by military dictatorship. ${ }^{26}$

These various interpretations of the concept of martial law are now considered in detail to determine whether it is necessary - or appropriate - for any Crown prerogative to impose martial law to be retained in modern times.

is often assimilated in spelling to marshal.sb. and it was a common opinion that 'marshal law' was so called as being the law emanating from the lord marshal.' Bellamy, n 5, p 231 'The phrases 'law marshall' or 'marshal law' were simply the English form of the Norman-French leys et usages d'armes and the latin leges et consuetudines...coram constabulario et marescallo...'.(ie. the laws and customs of the court of the constable and marshal). Anson (1935), vol 2, pt 1, 315 'Martial law ... is historically the law administered in the court of the constable and marshal, which included the administration of the regulations enacted by the Crown to govern its forces in war; it covers the military law under the Mutiny Act and the Army Act which superceded it.' Philips \& Jackson, n 16, 397 'In former times, what we now call military law was sometimes referred to as martial law.'

${ }^{21}$ That is, proclamations and commissions from the Crown to military personnel, authorizing them to apply military law to civilians.

${ }^{22}$ Halsbury, n 13, vol 8(2), para 821, n 1, 'the term 'martial law' is now generally applied to that state of affairs which exists in time of war, when the Crown by proclamation, or by notice issued by the military authorities, warns the public that certain offences will be tried and punished by a military court.' (italics supplied). Clode, n 19, vol 2, 162 (quoting Lord Brougham 'the proclamation of martial law renders every man liable to be treated as a soldier.').

${ }^{23}$ See 6. See also Gross, n 19, 33 quoting Corwin (1932), 97 'Martial law' in other words, is little more than a general term for the operation in situations of public emergency of certain well known principles of the common law - the right of self-defense of the individual, his right attended by the correlative liability - to abate a nuisance, his right and duty to arrest one whom he knows to have committed a felony or whom he observes in the act of committing a breach of the peace.'

${ }^{24}$ OED, $n$ 20, (definition of martial law).'That kind of military government of a country or district, by which the ordinary law is suspended, and the military authorities are empowered to arrest all suspected persons at their discretion, and to punish offenders without formal trial.' Dicey, $\mathrm{n}$ 16, 287 'Martial law, in the proper sense of that term, in which it means the suspension of ordinary law and the temporary government of a country or parts of it by military tribunals, is unknown to the law of England.' See also, pp 291 \& 293. Phillips \& Jackson, n 16, 398 refers to a variant on this, when limited to particular territory within a country 'The law administered by a military commander in occupied enemy territory in time of war. This is sometimes called martial law by international lawyers. It is unnecessary to say more than that the law so administered amounts to arbitrary government by the military, tempered by international custom (eg. the Hague Convention), and such disciplinary control as the British Government think fit to exercise.'

${ }^{25}$ For the full text of the Petition of Right (and the legislation cited therein), see Rushworth (1721), vol 1, 588-90. The Petition of Right is treated the same as a statute. See generally, McBain (2010) 545, n 64.

${ }^{26}$ Cromwellian government during the Civil War (1642-9) is the nearest England has come to military rule. However, this is not further considered since all statutes and ordinances of that period were repealed. Doubtless, if Britain were to have a military dictatorship it would claim that its acts were not specifically military but also civil and would argue for their legitimacy (to be rejected on a return to democracy). 


\section{Martial Law - Meaning Military Law Prior to 1688}

\subsection{Military Law: 1189 - 1660}

At least, since the Norman Conquest of 1066 up to the reign of Charles I (1625-49) it was accepted that the Crown (in the form of the sovereign in person) was commander-in-chief of the armed forces and that he (or she) alone had power to regulate them. ${ }^{27}$ Successive sovereigns recruited armies in England, in a variety of ways. In particular, by way of: military tenure, indenture and commissions of array. As to these:

- Subsequent to the Norman Conquest of 1066, William I (1066-87) granted land in England to subjects in return for an obligation to perform military duties (a system of military tenure) ${ }^{28}$ Thus, England was divided in some 60,000 'knight's fees' - each fee having a value of (possibly) £20 per annum. The obligation of the relevant knight (or soldier) was to attend the sovereign, when required, for 40 days, without pay, with the requisite horse and arms. ${ }^{29}$ This system of military tenure - often avoided by substitution or the payment of money from the time of Henry II (1154-89) - lingered on until its abolition by the Tenures Abolition Act 1660; ${ }^{30}$

- With the decline in military tenure, English armies often comprised English troops assembled by way of indenture - a form of contract in which the soldier agreed to serve for an allotted term at an agreed rate of pay. This system seems to have been rarely practised after the accession of Edward IV (1461-83); ${ }^{31}$

- English sovereigns also utilised commissions of array, an arrangement in which the sovereign granted commissions to selected officers, empowering them to assemble men capable of military action in a particular county, in military array. ${ }^{32}$ Hallam says the earliest example of a commission of array he could find was in 1324 , the latest in $1557 .{ }^{33}$ This system had become redundant by the time of James I $(1603-25) ;^{34}$

- English sovereigns also - from time to time - employed foreign mercenaries (stipendiaries). They also (albeit rarely) forcibly recruited (that is, impressed) soldiers, exercising the Crown prerogative (see 9). Sometimes, recruitment was also achieved by special practices such as recruiting criminals, a pardon being granted for their crimes;

As well as the army, English sovereigns also created special units of soldiers for specific purposes. ${ }^{35}$

\footnotetext{
${ }^{27}$ This almost certainly prevailed in Anglo-Saxon times as well. See the discussion in Samuel (1816), ch 1. See also McBain, n 1,16, n 20 (quoting Sir Thomas Smith, Coke, Blackstone and Fitzherbert).

${ }^{28}$ Prior to the Conquest, the position was not so certain although there was in place a system of the trinoda necessitas (the threefold necessity) where service of the citizenry was required to repel internal insurrection, foreign invasion (or the expectation of it) and the construction of military defences such as fortresses, public works, repairing bridges and highways. See Samuel, n 27, ch 1.

${ }^{29}$ Samuel, n 27, 18. In 1086, all the landholders in England were summoned to meet William I (1066-87) at Sarum (Salisbury) and to submit their lands to military tenure and take an oath of fealty. See ibid, 20. See also Blackstone, n 12, vol 1, 397 and Anson, n 20, vol 2, pt 2, 200. See also Carter (1944), 10.

${ }^{30}$ Military tenures (with minor exceptions such as grand and petty sarjeanty) were abolished by the Tenures Abolition Act 1660, s 4 . Walker (1980) (definition of military tenures) 'In feudal law, the tenures in which the duty owed was some form of military service, including grand sarjeanty, knight service, cornage [ie.sounding a horn to warn of the approach of an enemy], and the like.' See also McBain, n 25, especially 541. See also Maitland, n 17, 275-6; Tytler (1806), 30, 33 and Hume, n 4, vol 1, 362. Hallam, n 5, vol 2, 129 'The military tenants were frequently called upon in expeditions against Scotland, and last of all in that of 1640; but the short duration of their legal service rendered it, of course, nearly useless in continental warfare.' See also Clode, n 19, vol 1, 3

${ }^{31}$ Samuel, n 27, 32. See also Tytler, n 30, 42.

${ }^{32}$ Ibid, 28. By the time of Henry IV (1399-1413) it was accepted that such troops were not obliged to serve outside the realm, nor beyond the borders of their own county, save in cases of urgent necessity. In the time of Henry VIII (1509-47) lords lieutenant were appointed to execute such commissions. See also Maitland, n 17, 277-9 and Tytler, n 30, 32.

${ }_{33}$ Hallam, n 5, vol 2, 133 (citing Rymer (1727-35)). Cf. Hallam, n 5, vol 2, 133 (he refers to an Order in Council of 1638). See also Tytler, n 30 , 576-7 (commissons of array granted by Charles I (1625-49) deemed to be illegal and unconstitutional). See generally, Noyes (1930). See also Clode, n 19, vol 1, 31-2.

${ }^{34}$ The Statutes concerning Armour were repealed by 1 Jac 1 (1604) c 25 and 21 Jac 1 (1623) c 28. See also Blackstone, n 12, vol 1, 398 and Tytler, $n$ 30, 53. Charles I (1625-49), at the outset of his reign, published a proclamation commanding all persons who had an income of $£ 40$ per annum or more deriving from their land, to become knights. However, afterwards, he received a large composition in lieu of the same. See also Samuel, $\mathrm{n} 27,48$.

${ }^{35}$ Samuel, n 27, 32 mentions special groups such as the yeoman of the guard, sarjeants- at- arms and gentlemen pensioners. For the levying of troops by sovereigns up to the time of Charles I, see Samuel, n 27, ch 2. See also Hallam, n 5, vol 2, 131 and Clode, n 19, vol 1, 52.
} 
In the case of the royal navy in England - which developed later than the army - recruitment was usually by way of indenture or impressment. The latter comprised the forcible enlistment of men (usually mariners) by the Crown exercising its prerogative. ${ }^{36}$

When recruited, what law governed these people? Surprisingly, perhaps, it took time for the Crown to develop a coherent body of military (martial) law separate to the common law. Indeed, there was no attempt to systematise the same in writing until the time of Henry V (1413-22). Legal writers often refer to one of the earliest military laws being a charter of Richard I (1189-99). It applied to those going by sea to the Holy Land, on crusade ${ }^{37}$ and it was likely issued in 1189. The ordinance in question imposed barbaric punishments on military - and naval personnel in order to maintain discipline on board ship and it may have borrowed much from the laws of Oleron. ${ }^{38}$ Among other things, this ordinance provides:

He, who kills a man on ship - board, shall be bound to the dead man, and thrown into the sea; if a man is killed on shore, the slayer shall be bound to the dead body and buried with it. Anyone convicted by lawful witnesses of having drawn his knife to strike another, or who shall have drawn blood of him, to lose his hand. If he shall have only struck with the palm of his hand without drawing blood, he shall be thrice ducked in the sea. ${ }^{39}$

Later ordinances and statutes of war - up to 1422 - are as follows:

- Likely in 1385, Richard II (1377-99) promulgated 'The Statutes, Ordinances, and Customs to be observed in the Army;

- In the period 1415-21, Henry V (1413-22) promulgated - and likely expanded - various war statutes (De re Militari $)^{41}$ which were developed from the statutes and ordinances of Richard II. An article by Curry lists 5 versions and some 47 clauses. $^{42}$ The imposition of the death penalty for various crimes figures prominently; ${ }^{43}$

- To a certain extent these ordinances were supplemented by the law of treason. Thus, from early times, it was likely treason to desert the field of battle or to aid the enemy. ${ }^{44}$ The latter was enshrined in the

\footnotetext{
${ }^{36}$ See generally, McBain, n 1, 18-20. The Crown did not have its own ships until the reign of Henry VIII (1509-47).The first ship the Crown actually owned is said to be the 'Great Harry', built 1512-4, see Butler (1777), 69. This text contains useful references to writs and commissions to impress mariners from the time of king John (1199-1216). Prior to that, the Crown impressed ships and men to serve in wars (in particular, the Cinque Ports had an historic obligation to provide men and ships, for the crossing of the Channel). However, impressment was invariably of mariners, and by way of indenture (ie. accompanied by the payment of wages). See also Anson, n 20, vol 2, pt 2,217-8.

37 'Richard, by the grace of God, king of England, Duke of Normandy etc To all his men going by sea to Jerusalem, greeting. Know ye, by the common council of all good men, we have made the underwritten ordinances. ' See Samuel, n 27, p 60 and Brand \& Nelson (1867), 89. The LCJ was Cockburn CJ.

${ }^{38}$ The laws of Oleron are said to have been compiled by Richard I at the Isle of Oleron, off the coast of France. See also Blackstone, n 12, vol 4, 405 and Coke, n 11, vol 4, 144.

${ }^{39}$ Samuel, n 27, 60. See also Donaghan (2008), 142.

${ }^{40}$ See Samuel, n 27, 61. See also Twiss (1871), vol 1, 453-7 (copy of the statutes and ordinances). As Donaghan, n 39, 142, notes, these articles of war were very close to those of Henry V (as text above). For an ordinance of Edward III (1327-77) c 1348 (empowering captains of his galleys to try all crimes by sea and land), see Forsyth, n 5, 193. See also Brand, n 37, 89 and Hale, n 9, 120.

${ }^{41}$ Ibid, p 60. Henry V declares that "we have...promulgated the same in our army by public proclamation, enacting, that all and every one of the captains in our said army, shall have these our constitutions in writing, that our publication may be considered as a sufficient warning, and that all those concerned may not pretend ignorance of the said constitutions.' See also Samuel, n 27, 62; Rymer, n 33, vol 10, 106 and Hale, n 9, 120. ${ }^{42}$ Curry (2008), 214-49.

${ }^{43}$ eg. to: (a) touch the Eucharist or vessel in which it is held; (b) kill a cleric; (c) rape women; (d) go forward before the banner of their lord or master (unless authorized lodging personnel); (e) rob victuals; (f) make contest or debate in the host on account of past, or future, hatreds; (g) cry havoc; (h) raise the banner or pennon of St George (or any other )in order to draw men out of the host (ie. the army) to go anywhere; (i) give a safe conduct to a prisoner, or enemy, without authorization; (j) rob or pillage after peace has been proclaimed; (k) try to rescue a man condemned to death; (1) take beasts of labour without authorization; (m) reproach members of the army because of their nationality; (n) take an enemy who has been sworn or billeted - or anyone who owes allegiance to the king - other than to the ward of the constable or marshal;(o) carry out burning.

${ }^{44}$ See McBain (2007), 94-134. Glanvil (c. 1189) in his treatise held treason to cover 'betrayal of the realm'. So did Bracton (c.1240) .'Betrayal of the realm' probably included desertion, aiding the enemy and, possibly, levying war against the sovereign.
} 
Treason Act 1351 (still extant). ${ }^{45}$ This Act specified various individual treasons; these were then extended by subsequent legislation and by judicial constructive interpretations. The fact that desertion was not enshrined in legislation at any early stage ${ }^{46}$ is explicable by the fact that deserters were likely dispatched on (or near) the field of battle. ${ }^{47}$ As for senior commanders, they were impeached in Parliament in the period 1376-1559 for surrendering castles without the consent of the sovereign (after 1559 , to surrender a castle for a bribe was treated as treason under the Treason Act 1351). ${ }^{48}$

In respect of the enforcement of these statutes and ordinances of war, they would likely have been enforced by the king in person - as commander-in-chief - as well as by the Court of Chivalry (also called the court military or the court of the constable and marshal), a court which was operating prior to Richard II (1377-99). ${ }^{49}$ Adye (writing in 1769) summarises this court thus:

The court of chivalry, or marshal's court, the judges of which were the high constable, and the earl marshal, is the fountain of marshal law [i.e. martial or military] in England..$^{50}$

The marshal (or earl marshal) comprised an office which existed since the $12^{\text {th }}$ century. It has been held since 1672 by the Howards, Dukes of Norfolk. ${ }^{51}$ Another office was that of lord high constable - albeit it was placed in abeyance after 1521 so no such person sat in the Court of Chivalry after that date. ${ }^{52}$ This Court of Chivalry functioned in medieval times. However, its jurisdiction started to fall away after trial by battle became obsolete f $^{53}$ and after the common law encroached more and more on its civil jurisdiction concerning military contracts etc. ${ }^{54}$

- In respect of the military jurisdiction of the Court of Chivalry, since 1688 , it passed to courts martial; ${ }^{55}$

- One would suggest - however - that courts martial (i.e. military courts operated by military personnel, separate to the Court of Chivalry) existed long before 1688. Hallam maintains that the Court of Chivalry

\footnotetext{
${ }^{45}$ The Treason Act 1351 makes it a crime if a man 'be adherent to the king's enemies in his realm, giving to them aid and comfort in the realm, or elsewhere'. See McBain, $\mathrm{n} 44,119$ et seq.

${ }^{46} 18$ Hen VI c 19 (1439, rep) declared desertion to be a felony. See Samuel, n 27, 71-4; Blackstone, n 12, vol 1, 403 (who noted that a lighter penalty prevailed in practice in his time) and Burn (1799), 20 (fine and imprisonment). See also Bruce, n 4, 263 and Tytler, n 30, 41-5.

${ }^{47}$ Samuel, $\mathrm{n} 27,60$.

${ }^{48}$ McBain (2011b) 858-9. For the position during the Civil War (1642-9), see Samuel, n 27, 606 (Articles of the Earl of Essex, see n 71, 'if any town, castle, or fort, be yielded up, without the utmost necessity, the governor thereof shall be punished with death.').This punishment prevailed after the Civil War, see eg. Bruce, n 4, 259 (writing in 1717).

${ }^{49}$ Walker, n 30 (court of chivalry) 'A judicial body dealing with military disputes and questions of the law of arms. In most countries courts-martial regulating the conduct of persons involved in war came first. They were presided over by monarchs or great officers of state such as earls marshal. In time heralds became the principal officers of and practitioners before these courts and the law of arms became more and more concerned with rights to armorial bearings. In England the court of chivalry or court military, also known as the court of the constable and marshal, was held before the Lord High Constable and Earl Marshal of England. It had jurisdiction, civil and criminal, in deeds of arms and war, armorial bearings, matters of precedence, and, held before the earl Marshal alone, as a court of honour.' This court last sat in 1737. However, it was temporarily revived in 1955 to deal with armorial matters.

${ }^{50}$ Adye (1769) 1. See also Hawkins (1739), bk 2, ch 4 and Grazebrook (1895).

${ }^{51}$ Walker, $\mathrm{n} 30$ (definition of earl marshal). Adye (writing in 1769), n 50, 2 'The office of earl marshal still subsists, but his right of being one of the judges of martial law seems to have long since subsided.' See also Hale, $\mathrm{n}$ 9, ch 12.

52 This office was hereditary and the holder was an important military figure, commanding the royal army as well as being master of the horse. However, on the attainder of the $3^{\text {rd }}$ Duke of Buckingham in 1521, this office was extinguished. Edward Stafford, $3^{\text {rd }}$ Duke of Buckingham and Lord High Constable, was attainted of treason in 1521 for plotting against Henry VIII (1509-47), see Oxford Dictionary of National Biography (ODNB) (Earl of Stafford). See also, Coke, n 11, vol 1, s 102 (commentary) and Blackstone, n 12, vol 3, 68. For the great power of the Constable during the Wars of the Roses (1455-87), see Maitland, n 17, 266 and Tytler, n 30, 381-5. See also a commission of high constable of 1631. Ibid, 388-92.

${ }^{53}$ Trial by battle was formally abolished in 1819. See 59 Geo III c 46 (1819) which was subsequent to Ashford v Thornton (1819) 1 B \& Ald 405 (106 ER 149) (appeal of felony). See generally on the role of the court in such matters, Coke, n 11, vol 4, 122-3 (who cites various cases) and Bellamy (1970).

${ }^{54}$ Blackstone, n 12, vol 3, 103. Stephen, n 19, vol 1, 208 says that 'When standing armies were introduced [ie. after 1688], the powers of the constable and marshal fell into disuse.' However, the latter occurred before 1688. Capua, n 19, 158 considered that the Court of Chivalry was not functioning by 1496 .

${ }^{55}$ Holdsworth (2009), vol 1, 577 'Since 1689 jurisdiction over the army has passed to these courts martial which have been legalized and extended by the successive Mutiny Acts of the eighteenth and nineteenth centuries. Thus, the military jurisdiction of the court of the Constable and Marshal ceased to exist because it was not needed.'
} 
fell into disuse under the Tudors. ${ }^{56}$ Further, at least on the continent, courts martial were referred to as early as $1570 .^{57}$

In respect of the rise of courts martial - and the decline of the Court of Chivalry - reference to the former may have been made as early as the ordinances of Henry V (1413-22); they refer to army personnel being condemned to death by:

king, constable, marshal [ie. the Court of Chivalry] or 'judge ordinary [i.e. common law courts] or any other officer lawful' (italics supplied). ${ }^{58}$

As for the position, post-1422, in respect of the promulgation by the Crown of military ordinances: ${ }^{59}$

- In 1487, various Ordinances of War were proclaimed by Henry VII (1485-1509). ${ }^{60}$ And, certain Statutes and Ordinances of War were published in $1491 ;^{61}$

- In the reign of Henry VIII (1509-47), various statutes and ordinances of war were promulgated in May 1513, prior to war with France. ${ }^{62}$ More followed in 1544; they contained some 54 articles; ${ }^{63}$

- Subsequent to this, there was tendency for articles of war to be made by the commander-in-chief under commission from the sovereign. Thus, the Earl of Leicester made such articles in $1585-6^{64}$ and, in 1622, James I (1603-25) issued a commission to Sir Horace Vere, Captain - General of the army, 'To make and proclaim ordinances of war, for the government of the army, and to enforce the observation thereof. ${ }^{65}$

It may also be noted that royal proclamations expressly imposed martial law on mariners and soldiers, where there might be doubt. For example, Elizabeth I (1558-1603) issued a proclamation in 1585 that various soldiers, levied to fight in the Low Countries under a commission granted by her to Sir John Norris (Norreys), were subject to his orders and that those who had received pest [i.e. press] money and who offended against such orders or sought to withdraw

\footnotetext{
${ }^{56}$ Hallam, n 5, vol 1, 240. Hale (1971), 27-8 states 'In this military court, court of honour, or court martial, the civil law has been used and allowed in such things as belong to their jurisdiction; as the rule or direction of their proceedings and decisions, so far forth as the same is not controlled by the laws of this kingdom, and those customs and usages which have been obtain'd in England, which even in matters of honour are in some points derogatory to the civil law. But this court has long been disused upon great reasons.' (spelling modernized). See also Baker (2003), vol 6, 216-9 and Tytler, n 30, 46. Also, Squibb (1953) and Grazebrook, n 50.

${ }^{57}$ Bruce, $\mathrm{n}$ 4, 315 refers to an Edict by the Duke of Alva (Fernando de Toledo (1507-82), a mercenary commander and governor of the Low Countries (the Spanish Netherlands) in 1570) 'That a court martial shall be the sole judge in all military crimes'.

${ }^{58}$ Cf. Adye, n 50, 2 'When this sort of court [ie courts martial] was first instituted, I cannot exactly ascertain'. See also Brand, n $37,95$.

${ }^{59}$ See generally Donaghan, $\mathrm{n} 39$, ch 8 . 'English ordinances or articles of war...had a long history, but they underwent a revolutionary change in the late sixteenth century.'

${ }^{60}$ Hughes \& Larkin (1969), vol 1, 14. These ordinances were very short and imposed the death penalty for: (a) robbery, including robbing churches; (b) ravishing women; (c) taking victuals without paying the reasonable price thereof. Also, they stipulated imprisonment for various other offences. The proclamation ended 'And whensoever it shall please the king...to command any of his officers of arms to charge any thing in his name, by his high commandment or by the commandment of his constable or marshal, that it be observed and kept, upon pain of imprisonment and his body to be punished at the king's pleasure.' See also Samuel, n 27, 63.

${ }^{61}$ Here Begynneth Certain Statutes and Ordenaunces of Warre made ordeined enacted and estalysshed by the most noble victorious and most christen Prince oure moste drad souerayn Lord King Henry the VII. King of Fraunce and of Englond (1492)(rep EEBO eds, London. Printed by Richard Pynson, 1492?). See also Beadle \& Hellinga (2001), 2 (2):107-119.

${ }^{62}$ Hereafter Ensure Certaine Statuts and Ordenances of Warre made etc by Kynge Henry the VIII (1513). See also Hughes \& Larkin, n 60 , 106-20. Everyone was made obedient to the king and to the marshal of the host, on pain of death.

${ }^{63}$ These statutes were promulgated prior to the embarkation of Henry VIII on an expedition against France in 1544.They state 'His Majesty, minding due order to be observed and kept among all sorts of men of his highness's most royal and puissant army, as well captains, soldiers as others, in such wise as appertained both towards God and the world, hath devised and commanded to be set forth certain ordinances and statutes for the war, as hereafter ensueth etc.' See also Samuel, n 27, 64.

${ }^{64}$ Lawes and Ordinances set down by R. Earle of Leycester the Queenes Maiesties Lieutenant and Captain General of her armie and force in the Lowe Countrie is meete and fit to be observed by all such as shall serve in the said countries (1586). The Earl of Leicester was Robert Dudley (1532/3-88), see ODNB, n 52. See also Donaghan, n 38, 144. In 1593, Sutcliffe (1593) published his military text.

${ }^{65}$ Sir Horace Vere, 1st Baron Vere of Tilbury (1565-1635), see ODNB, n 52. See also Donaghan, n 39, 145 (ordinances of 1625 \& 1627).
} 
Her majesty doth hereby notify that every such person so offending, and the offence duly proved, shall be punished with death by martial law. ${ }^{66}$

At the outset of the Civil War (1642-9), both the Crown and Parliament issued military ordinances:

- On the side of the Crown, in 1639, the Earl of Arundel (Charles I's general against the Scots) published Laws and Ordinances of Warre. ${ }^{67}$ And, in 1640, the Earl of Northumberland, Lord General of the royalist army, published 'Laws and Ordinances of Warre'; ${ }^{68}$

- On the side of Parliament, in 1642, Robert Rich ( $2^{\text {nd }}$ Earl of Warwick) Lord General, ${ }^{69}$ published 'Laws and Ordinances of Warre' established for the better conduct of the Army. ${ }^{70}$ In 1643, the Earl of Essex, Lord General, published similar laws and ordinances, which remained in force in the Parliamentary army throughout the Civil War. ${ }^{71}$

Analysing the laws and ordinances of the Earl of Warwick, it may be noted that they imposed the death penalty for a large number of offences. ${ }^{72}$ Indeed, out of the 90 odd offences mentioned, no less than 43 were punishable with death. Some of these were for relatively small infractions, viz.

None in their march through the counties shall waste, spoil or extort any victuals, money, or pawn from any subject, on pretence of want whatsoever, on pain of death (spelling modernised).

Even when death was not imposed, penalties for offences were often stated to be the 'severest' or 'without mercy'. Further, these rules were declared to be supplementary to the 'general customs and laws of war. ${ }^{73}$ Finally, there was also a heavy moral overtone to them. ${ }^{74}$ Donaghan, having analysed the most comprehensive versions of the articles of war of the Crown and of Parliament in the Civil War period (1642-9), concludes:

${ }^{66}$ Hughes \& Larkin, n 60, vol 3, 27 (proclamation of 4 October 1588). For a proclamation subjecting volunteers under letters of marque to martial law in April 1545, see ibid, n 60, vol 1, 348. For Sir John Norreys (1547-97) see ODNB, n 52.

${ }^{67}$ Donaghan, $\mathrm{n} 39$, 146. The Earl of Arundel referred to be Thomas Howard, $14^{\text {th }}$ Earl (1585-1646), see ODNB, n 52. See also Clode, $n$ 19, vol 1, 22-3 \& 429-40. See also Clode (1872).

${ }^{68}$ Samuel, $\mathrm{n} 27,65$. This was the $10^{\text {th }}$ Earl of Northumberland, $4^{\text {th }}$ Baron, Algernon Percy (1602-88). See also those of the Earl of Holland in 1641, ibid, p 147. See also Brand \& Nelson, n 37, 91.

${ }^{69}$ Robert Rich (1587-1658), see ODNB, n 52.

70 Entitled 'The Lawes and Ordinances of Warre established for the better Conduct of the Army', it is addressed to 'all the Officers of the Army, Colonels, Captains, Elder Sarjeants, other Officers and Soldiers of Horse and Foot, and all others whom the Laws and Ordinances may concern' See also The Laws of War and Ordinances of the Sea (established and ordained by the Parliament of the Commonwealth, 1652 - it lists 39 offences) and Laws and Ordinances of Warre established for the Good Conduct of the Army by Colonell Michael Jones (printed by William Bladen, 1647). Spellings have been modernized. See also Donaghan, n 39, 148-51 and Acland (1921) 190-201. The Instructions of the Admirals and Generals of the Fleet for Council of War issued in 1653 instituted the first naval courts martial in the English navy. See also the Cadiz Expedition's Instructions issued in 1596 by the Earl of Essex and Lord Howard of Effingham (29 articles).

${ }^{71}$ R Devereux, Laws and Ordinances of War established for the better conduct of the Army by his Excellency the Earl of Essex, Lord General of the Forces raised by the Authority of the Parliament (London, printed for J Partridge \& J Rothwell, 13 ${ }^{\text {th }}$ May 1643). See also Samuel, n 27, p 65. For Robert Devereux, (1591-1646), $3^{\text {rd }}$ Earl of Essex, see ODNB, n 52. See also Scott, n 19, 56; Clode, n 19, vol 1, 24 \& 442-5 and Holds worth, $\mathrm{n} 55$, vol 6, 226

${ }^{72}$ viz (a) intelligence with the enemy; (b) releasing the enemy; (c) yielding up forts; (d) violating a safeguard; (e) spies; (f) using words tending to the death of the Lord General; (g) striking an officer; (h) leaving the captain (or a servant, his master); (i) resisting against correction; (j) mutinous assembly; (k) resisting the provost marshal; (1) seditious words; (m) rape and unnatural abuses; (n) theft above 12d; (o) murder; (p) embezzling munitions; (q) waste and extortion; (r) taking horses from the plough; (s) straggling from the colours; (t) swerving from the camp (ie. departing more than a mile from the army or camp); (u) drawing swords after the watch is set; (v) giving a false alarm; (x) revealing the watchword; (y) offering violence to victuallers; (z) sentinel asleep or drunk; (aa) remaining unrolled (ie. unregistered) in the army; (bb) failing at the rendezvous; (cc) departing without leave; (dd) failing to repair to his colours; (ee) deserting the battlefield; (ff) throwing away weapons; (gg) burning houses or spoiling crops of friend or foe; (hh) throwing away gunpowder; (ii) embezelling booty; (jj) concealing prisoners; (kk) pillaging without licence; (11) failing to prevent duels (for commanders and officers); (mm) drawing a sword against an officer; (nn) mustering false and counterfeit troops (for commanders and officers); (oo) embezzling food and munition (for commanders and officers); (pp) muster masters conniving at counterfeits; (qq) presenting oneself in a muster by a counterfeit name or surname; (rr) braving (ie. defying) the marshall's court.

73 'All other faults, disorders, and offences not mentioned in these articles, shall be punished according to the general customs and laws of war'.

${ }^{74}$ eg. 'Let no man presume to blaspheme the holy and blessed trinity, God the father, God the son, and God the holy ghost; nor the known articles of our Christian faith, upon pain to have his tongue bored with a red hot iron.' Also, 'All those who often and willfully absent 
Of the offences in the royalists' one hundred and fifty-three articles, fifty-four (35 per cent) merited death; of these the penalty was mandatory for thirty and discretionary for twenty-four. In parliament's one hundred and two articles, forty-eight offences ( 47 per cent) merited death but the penalty was mandatory for only fourteen and discretionary for thirty-four. ${ }^{75}$

Finally, it may be noted that - in the Civil War - on the royalist side, persons fighting for Parliament were often executed - as 'traitors and rebels' - not on the basis of any ordinance or statute of war, but on the basis of the law of treason under the Treason Act 1351, since it was a sub-crime under that Act:

if a man do levy war against our lord the king in his realm. ${ }^{76}$

Perhaps bizarrely, Parliamentarians often executed royalists on the same basis - arguing that its soldiers were engaging in war against Parliament and that this comprised rebellion and treason against the king pursuant to the laws and statutes of the realm. ${ }^{77}$ As to the meaning of 'martial law' - by the time of the Civil War - it was being used synonymously with 'military law', as Donaghan notes:

Contemporaries referred to the articles of war indiscriminately as martial law or military law... ${ }^{78}$

Donaghan also refers to occasions when Parliament applied martial law to civilians. Thus, in 1644, Parliament gave power to a commission of soldiers and MP's to apply martial law to civilians accused of plotting with the enemy (i.e. with Charles I). ${ }^{79}$ Also, in 1645, a council of war (against the background of a possible seizure of Dover castle) was empowered to punish all cases that came under military cognizance. Both these powers were only temporary. ${ }^{80}$

In conclusion, the statutes and ordinances of war - from Richard I in 1189 to the end of the Civil War in 1649 evidence that the Crown's exercise of the royal prerogative to impose martial law was plenary. The clear intent of these statutes and ordinances of war were to impose the death penalty (and more severe and unusual punishments) on military personnel in cases where the common law did not. ${ }^{81}$ Thus, martial law prior to 1688 was ill framed, extensive (prodigal) and designed to apply 'in terrorem, ${ }^{82}$

\subsection{Military Law post-1660}

Although, on the restoration of the monarchy, Charles II (1660-85) abolished military tenure, ${ }^{83}$ he retained a standing army of 5,000 men. James II (1685-8) increased this to some 15-20,000 men after the Monmouth rebellion of June - July $1685 .{ }^{84}$ The paramount control of the Crown in respect of military matters was re-stated in the Preamble to the Militia Act of 1661which declared that:

themselves from sermons, and public prayer, shall be proceeded against at public discretion: And all such who shall violate places of public worship, shall undergo severe censure.'(Spelling modernized).

${ }^{75}$ Donaghan, n 39, 170.

76 'si home leve de guerre contre nre dit seignr le roi en son roialme.' See generally, McBain, $\mathrm{n} 44$ and Donaghan, n 39, 130-1.

${ }^{77}$ Dongahan, n 39, 130-1.

${ }^{78} \mathrm{Ibid}, 171$. Cf. 173, 'It is important to remember that in the war years 'martial law' was more likely to bear the neutral meaning of military law than the constitutionally loaded modern sense.' Holdsworth, n 19, 120 'It became known not as martial but as military law.'

${ }^{79}$ See Tytler, n 30, 71-9. Also, Cobbett (1812), vol 13, 270.

${ }^{80}$ Donaghan, n 39, 172. See also Brand \& Nelson, n 37, 45-6.

${ }^{81}$ Samuel, n 27, 97-8 refers to military punishments such as dis-memberment, maiming (or fracturing) of limbs, boring the tongue with a red hot iron, cutting off the left ear, branding the cheek, running the gauntlet (gantlope), riding the wooden horse and the whirligig (a circular wooden cage which was whirled round). See also Donaghan, n 39, 179, 182.

${ }^{82}$ Donaghan, n 39, 142, 'Military punishments for breaches of military law were shaped by principles of flexible, exemplary, and 'in terrorem' administration of justice.' See also 194. Some of the ordinances applied not only to military personnel but to those who trafficked with them. For example, the ordinances of Henry V (1413-22) provided that common women (prostitutes) who came within the king's army (or within 3 miles of the same) were to be burnt on the right cheek (first offence) and - for a second offence - to be imprisoned as long as should please the marshal. Such a woman who remained in any fort, or garrison, after being ordered to quit the same was to have her left arm fractured. See Samuel, n 27, 92-3.

${ }^{83}$ See $n$ 30.See Clode, n 19, vol 1, 446-9 (Orders and Articles of War, 1666).

${ }^{84}$ Samuel, $\mathrm{n} 27$, ch 4 (Blackstone gives the figure as 30,000, see n 12, vol 1, 401). At 168, 'the military part of the feudal policy was formally abolished... at the Restoration [1660]; but the successive kings of England uninterruptedly exercised the right of commanding and legislating for the army, to the period of the Revolution [of 1688].' One of the earliest texts on military law (it is more a work on the drilling of soldiers) is Anon, Abridgment of the English Military Discipline (rep by his Majesty's special command, 1682. The 1686 edition, printed by Charles Bell et al, London, has been reprinted by EEBO). See also Harford (1680). 
The sole supreme government command and disposition of the militia and of all forces by sea and land and of all forts and places of strength is and by the laws of England ever was the undoubted right of his majesty and his royal predecessors kings and queens of England. ${ }^{85}$

However, lasting change to this - and to the unfettered control of the military by the Crown - occurred when James II abdicated and William and Mary (1689-1702) were chosen by Parliament as king and queen. Indeed, the foundations of modern military law commence with the provision in the Bill of Rights 1688 that:

The raising and keeping a standing army within this kingdom in time of peace unless it is with the consent of Parliament is against law. ${ }^{86}$

In 1688 , in order to deal with a mutiny that had taken place, ${ }^{87}$ Parliament enacted the first of the Mutiny Acts, to punish mutiny and desertion (these Mutiny Acts were annually renewed thereafter) ${ }^{88}$ This Mutiny Act of 1688 also authorised the Crown to establish courts martial, replacing any Crown prerogative in respect of the same with legislation. ${ }^{89}$ Samuel, in his Historical Account of the British Army (1816), noted:

From the exercise of the power of legislation over the higher order of offences, and from the assertion of a like right in all, the step to the actual assumption of an authority by the parliament over military offences in general, was short and in the usual course of things. From year to year this legislative power was manifested in successive mutiny acts, each discovering some new accession of influence, until it became universally prevalent. ${ }^{90}$

Martial law (military law), therefore, after 1688 became a separate body of law which governed the armed forces alone and not civilians. Samuel stated:

Military or martial law...is a particular rule of conduct, prescribed by the legislative authority of the state, for the government of the military force of the nation, in contra - distinction to the law, which regulates, or is intended to regulate the general conduct of the people in their civil relations. ${ }^{91}$

${ }^{85} 13$ Car II st 1 c 6 (1661) (rep) (king's sole right over the militia). See also 14 Car II (1662) c 3 and 15 Car II (1663) c 4. These three Acts remained the statutory authority for the militia until 1757. See also Blackstone, n 12, vol 1, 399; Samuel, n 27, 162; Robertson (1935), 28 and Tytler, n 30, 95-6.

${ }^{86}$ Samuel, $\mathrm{n} 27, \mathrm{p} 149$ 'The declaration....made the parliament, in effect, a constituent power in the creation of the army; which, thenceforward, could not look to the Crown, as in foregoing seasons, as the sole author of its being.' See also Blackstone, n 12, vol 1, 401; Forsyth, n 5, 207; Tytler, n 30, 101 and Clode, n 19, vol 1, 499.

${ }^{87}$ This was a mutiny among troops quartered at Ipswich. They disarmed their officers, seized the regimental chests and declared for James II (1685-9). Also, about 500 troops attached to the Royal Scotch and Dumbartons' regiments deserted. The mutiny was soon quelled. See also Tytler, n 30, p 102; Scott, n 19, 58 and Clode, n 19, vol 1, 142.

${ }^{88} 1$ Will \& Mar c 5 (rep) 'every person being ... mustered and in pay as officer or soldier who shall... excite cause or join in any mutiny or sedition in the army or shall desert their majesties service in the army, shall suffer death or such other punishment as by a court-martial, shall be inflicted.' See also Samuel, n 27, 138 and Robertson, n 85, 110-1. The Mutiny Act became the Army Act in1881, see Anson, n 20, vol 2, pt 2, 203.

${ }^{89}$ It authorized (s 3) their Majesties or the general of their army to grant commissions to any lieutenant general (or other officers not under the rank of colonel) to call, and assemble, courts-martial. See also Samuel, n 27, pp 138-9. In 1718, courts martial were allowed to punish mutiny and desertion with death, see Hallam, n 5, vol 2, 261. It may be noted that, in the $1^{\text {st }}$ World War (but not the $2^{\text {nd }}$ World War), desertion was still punishable with death.

${ }^{90}$ Samuel, n 27, 139. In Grant v Gould (1792) 2 H Bl 69 (126 ER 434) per Loughborough CJ at 98, 'Where martial law prevails, the authority under which it is exercised claims a jurisdiction over all military persons, in all circumstances...' See also Samuel, n 27, 184. Forsyth, n 5, 553 'These regulations [passed under the Mutiny Acts] form a code which is sometimes called martial, but more properly military law'.

${ }^{91}$ Ibid, Introduction. Also, 'It will be seen, in the progress of the inquiry, that the military regulations, obtaining in the earlier periods of our history, were not formed, as now, for the control of a separate class of men, but for the whole mass of the people; not operative on a particular body, but on the members of the community at large, each one of whom being liable, when capable of bearing arms, to the burden of military service. These regulations enjoined certain duties on citizens, under described penalties, when acting in the capacity of soldiers; but as such capacity was occasional only, the regulations having reference to it, had but occasional force.'Wolton v Gavin (1850) 16 QB 61 (117 ER 794 ) per Campbell CJ at 61 'none are bound by the Mutiny Act or the Articles of War except her Majesty's forces: and I am most anxious, as a constitutional judge, that this should be fully understood to be my opinion.' In 1879, the provisions of the Mutiny Act and of the Articles of War were consolidated into a code of military law, the Army Act 1881. Anson, n 20, vol 2, pt 2, 215 'The effect of the substitution of the present Army Act [ie. of 1881] for the old Mutiny Act is to bring the entire code of military law annually under the consideration of Parliament, which no longer gives power to make rules and constitute courts, but enacts the rules, provides the jurisdiction for enforcing them, and the punishments for their breach.' 
As a result, references to 'military law' became more and more common ${ }^{92}$ and the term 'martial law' became reserved to situations where military law was imposed over subjects in extreme cases - such as in the case of plots, rebellions or war time. ${ }^{93}$ This can be seen in changes in texts on military law from the $18^{\text {th } 94}$ to the $19^{\text {th }}$ centuries. ${ }^{95}$ By 1881 - at the latest - with the Army Act 1881, legislation covered the field of military law. ${ }^{96}$ Thus, any reference to martial law imposed by virtue of the Crown prerogative (except in the case of plots, rebellions and war, see 4 and 5) was eclipsed - as was the distinction between 'martial' and 'military law' when referring to the law governing the armed forces. ${ }^{97}$

In conclusion, martial law - in so far as it refers to the law imposed by the Crown on military personnel prior to 1688 - no longer has any meaning. All the Crown statutes and ordinances of war dealing with the same up to that date - including the imposition of the death penalty, other military punishments, the Court of Chivalry and courts martial established pursuant to the Crown prerogative - have long been superceded by legislation. With legislation covering the field, the term 'martial law' has become subsumed into the term 'military law'; which, today, refers to that body of law governing the armed forces but not civilians. Thus, any Crown prerogative to impose 'martial law', when used as an archaic reference to 'military law', is wholly obsolete.

\section{Martial Law - Military Law Imposed on Civilians in Peacetime}

As well as comprising an early reference to military law in general, the term 'martial law' was often more specifically used to describe the application of military law to civilians in peacetime. Legal writers in the $17^{\text {th }}$ and $18^{\text {th }}$ centuries asserted - in strong terms - that this was not possible for the Crown to do, since it was made illegal by the Petition of Right 1627 (still extant).

\subsection{Deprecation of Martial Law by Legal Writers}

Martial law - in the context of legal writers such:

- Lord Coke (his Institutes of the Laws of England were published between 1628-41);

- Hale CJ (his History of the Common Law of England was written between 1640's - 1660's but first published in 1713); and

- Blackstone (his Commentaries on the Laws of England were published between 1765-9)

\footnotetext{
92 OED n 20, (military law) 'the body of enactments and rules for the government of an army.' Bruce, $\mathrm{n} 4$, (writing in 1717) refers to military law and not martial law eg. 3 'Since war then is the occasion of the military law...' Tytler (writing in 1806), n 30, 1 'The foundation of the military or martial law, is that which is common to all law whatever - the necessity of things.' Dodd, n 19, 152 'martial law ...down to the end of the seventeenth century, if not later, is what we now call military law.'

${ }^{93}$ Samuel, $\mathrm{n} 27, \mathrm{xv}$ deprecates 'imaginary resemblances, or from abuse of terms, fancied to be synonymous, but certainly not convertible, in assuming the law military to be the same thing with what commonly passes under the denomination of martial law; which will appear, on examination, to be nothing more than the offspring of necessity, covering itself with the clothing and taking the name and place of law, though in reality it be, if not a subversion, at least a temporary supercession of all that is sound in legislation, justified and justifiable only in perilous and critical conjunctures, when social order is vitally threatened; when violence can only be resisted by violence; when the sense of danger is so imminent, as to overwhelm every other consideration; where the end or existence of society is sustained, in a natural and spontaneous preference, to the means by which it is brought and held together; when the public safety is preserved at the expense of the public ordinances.' ${ }^{94}$ Brewster (1725) ; Burn, $\mathrm{n} 46$. Cf. Sullivan (1779)(treats martial law the same as military law, eg 2 'the law martial of England is indisputably authorized by an act of the legislature.').

${ }_{95}$ Adye (1769), n 50; Tytler, n 30, Hardesty (1718), Samuel, n 27 and Bruce, n 4.

${ }^{96}$ See $\mathrm{n}$ 91.See also Stephen, n 19, vol 1, 208. Referring to Victorian legislation he states 'They form a code, which is sometimes called martial, but more properly military, law.'

${ }^{97}$ Heuston, n 16, 151 'martial law includes first, military law.' Samuel (writing in 1816), n 27, 186 'The law military, whatever might have been its range in older times, is now restricted in its obligatory force to the definition and declaration of the duties of soldiers, and the enforcement of them, under appropriate penalties.' At 187 'At the commencement of the reign of Queen Anne [ie. 1702,] the Mutiny Act had made a large stride towards a general jurisdiction, not only in primary but in secondary acts of crime; so as to leave little that is essential to complete the exercise of the ordinary legislative power over the entire list of offences, peculiar to the military state.' At 203-4 'Towards the end of the reign of George the Second [1727-60], nearly the whole mass of the offences, of which officers or privates, might be guilty, is embraced by the Mutiny Act; not, perhaps, so distinctly or precisely as at this day, but enough to show that the legislature had the intention of exercising, and were actually exercising, a full and general authority therein.'(Spelling modernized).
} 
tended to comprise a reference both to military law imposed by the Crown prerogative prior to $1688^{98}$ and, in a narrower context, to military law applied to civilians in peacetime. In both senses, these legal writers strongly dis-approved of it. The first, because it was excessive and arbitrary in comparison with the common law depending solely on the will of the sovereign (see 2). The second, because it was made illegal by the Petition of Right 1627. Blackstone (in 1765) stated:

For martial law, which is built upon no settled principles, but is entirely arbitrary in its decisions is as sir Matthew Hale [ie. Hale CJ] observes, in truth and reality no law, but something indulged, rather than allowed as a law: the necessity of order and discipline in an army is the other thing which can give it countenance; and therefore it ought not to be permitted in time of peace, when the king's courts are open for all persons to receive justice according to the law of the land. ${ }^{99}$

Blackstone referred to Hale CJ who stated, in his History of the Common Law:

But touching the business of martial law, these things are to be observed, viz. First, that in truth and reality it is not a law, but something indulged rather than allowed as a law; the necessity of government, order, and discipline in an army, is that only which can give those laws a countenance, quod enim necessitas cogit, desendit. ${ }^{100}$

Secondly, this indulged law was only to extend to members of the army, or to those of the opposite army, and never was so much indulged as intended to be (executed or) exercised upon others; for those who were not listed under the army, had no colour of reason to be bound by military constitutions, applicable only to the army, whereof they were not parts; but they were to be order'd and govern'd according to the laws to which they were subject, though it were a time of war. ${ }^{101}$

Thirdly, that the exercise of martial law, whereby any person should lose his life or member, or liberty, may not be permitted in time of peace, when the king's courts are open for all persons to receive justice, according to the laws of the land. This is, in substance, declared by the Petition of Right [1627],3 Car 1, whereby such commissions and martial law were repealed and declared to be contrary to law. ${ }^{102}$

Both Blackstone and Hale referred to Coke and the third volume of his Institutes (published in 1641). He stated:

\footnotetext{
${ }^{98}$ Brand \& Nelson, n 37, 78 'it must be borne in mind that, as appears from the language of Lord Coke and Lord Hale, the term martial law, as understood at that time, meant simply military law.' See also, 99-100.

${ }_{99}$ Blackstone, n 12, vol 1, 400. Both Samuel (n 27) and Tytler, n 30 (eg vii, 12-3) assert that Blackstone - in his denigration of martial law - was inaccurate when describing the position in his time. This is true. However, it is more likely that Blackstone was indicating that martial law was 'no law' with reference to the position pre-1688. See also Samuel, n 27, 171 et seq Further, Blackstone (see n 12, vol 1, 403) was unhappy that Articles of War promulgated by the Crown pursuant to the various Mutiny Acts, were so indeterminate - something which no longer prevails since the Army Act 1881. Clode, n 19, vol 2, 162 'Martial law exercised against enemies or rebels is only a more regular and convenient mode of exercising the right to kill in war: a right originating in self-defence... It is nothing more than a sort of better regulated decimation, founded upon choice, instead of chance.'

100 'Because necessity compels, descend'. However, it should be 'quod enim necessitas cogit, defendit' (it is to be defended/justified because necessity compels), see Brand, n 37, 57. A similar sentiment may be found in Hardesty, $n$ 95, xi who (writing in 1718) said that a person who refers to the 'long and heavy train of military charges formerly laid on our ancestors, for the honour and defence of their country may just[ly] conclude that those ages were rather a state of meer [mere] slavery and servitude than of the so much boasted freedom of the subject.' See also Sullivan, n 94, 2 'Martial law, in general hath been defined, a temporary execresence, bred out of the distemper of the state, and not as any part of the permanent and perpetual laws of the kingdom.'

${ }^{101}$ Hale, n 56, 26 'Always, preparatory to an actual war, the kings of this realm, by advice of the constable (and marshal), were used to compose a book of rules and orders for the due order and discipline of their officers and soldiers, together with certain penalties on the offenders; and this was called martial law. We have extant in the Black Book of the Admiralty, and elsewhere, several examples of such military laws.' See Anson, n 20, vol 2, pt 2, 214.

102 Ibid, 27. See also Grant v Gould (1792) 2 H Bl 69 (126 ER 434) per Loughborough CJ at 98 'martial law, such as it is described by Hale, and such also as it is marked by Mr Justice Blackstone does not exist in England at all. When martial law [ie. military law] is established and prevails in any country, it is of a totally different nature from that which is inaccurately called martial law, merely because the decision is by court martial, it bears no affinity to that which was formerly attempted to be exercised in this kingdom, which was contrary to the constitution, and which has been for a century totally exploded. Where martial law [ie. military law] prevails, the authority under which it is exercised, claims a jurisdiction over all military persons, in all circumstances.' The words in italics refer to the position pre-1688.
} 
If a lieutenant, or other that hath commission of martial authority, in time of peace hang, or otherwise execute any man by colour of martial law, this is murder for it is against Magna Carta, cap $29^{103}$ and is done with such power and strength, as the party cannot defend himself; and here the law implied malice. ${ }^{104}$

In denying the right of the Crown to impose martial law over citizens in peacetime, all of Coke, Hale and Blackstone referred to the precedent of Edmund of Woodstock. He was Earl of Kent (1301-30) and the brother of Edward II (1307-27). ${ }^{105}$ It was said that letters of his containing treason (a plot to free the deposed Edward II) were shown to his nephew, Edward III (1327-77) and that Edmund acknowledged this before the coroner of the king's household, when arrested. Articles of treason were then brought against Edmund in Parliament in March 1330 and (it seems) he acknowledged them. He was sentenced (as Hale puts it) by 'a kind of military court by a summary proceeding'. However, in 1331, this judgment (attainder) was reversed in Parliament (albeit after his execution) and Edmund was formally pardoned because he was executed without a proper trial in time of peace (tempus in quo morte adjudicatur fuit, fuit tempus pacis). ${ }^{106}$ Hale CJ continues:

And accordingly the judgment [against Edmund, Earl of Kent] was revers'd; for martial law, which is rather indulg'd than allow'd, and that only in cases of necessity, in time of open war, is not permitted in time of peace, when the ordinary courts of justice are open. ${ }^{107}$

Thus, all three authors argued that martial law should not apply to civilians in peacetime - citing the precedent of the Earl of Kent in 1330. And peacetime was when the king's courts were open. However, it seems clear that despite this precedent - until the Petition of Right 1627 there were many instances in English history where the Crown sentenced people to death, pursuant to some form of military tribunal in peacetime. These are now considered.

\subsection{Proclamations and Commissions Imposing Martial Law - Pre-1625}

The background to the Petition of Right 1627 is that martial law was applied to civilians in the course of English history during peacetime - albeit this was relatively rare. Cases cited by Coke of important persons being tried by martial law in peacetime - besides Edmund, the Earl of Kent in 1330 (see above) - are:

- Thomas, Earl of Lancaster. The cousin of Edward II (1307-27), in 1322, he was tried for treason for levying war against that sovereign ('with banners displayed', explicatio vexilli regis). ${ }^{108}$ It seems he was

\footnotetext{
${ }^{103}$ Magna Carta 1297, ch 29 (still extant) provides 'No man shall be taken, or imprisoned, or be dis-seized of his freehold, or liberties, or free customs, to be outlawed, or exiled, or any other wise destroyed; nor will be pass upon him, nor [condemn him] but by lawful judgment of his peers, or by the law of the land...'See also also GS McBain, Abolishing Obsolete Legislation on Crimes and Criminal Procedure, Legal Studies, (Dec 2010), vol 30, no 3, pp 1-12

${ }^{104}$ Coke, $\mathrm{n} 11$, vol 3, 52. One would assert that Coke was wholly right in this in that the Court of Chivalry (re criminal matters) in peace time was part of the king's court and, thus, it was 'open' qua the king's court. Grazebrook, n 30, 7 'Court of Chivalry; during times of war it was with the army, and in times of peace sat in the aula regis, or king's great court.' Blackstone, $\mathrm{n}$ 12, vol 1, 400 'And it is laid down, that if a lieutenant, or other, that hath commission of martial authority, doth in time of peace hang or otherwise execute any man by colour of martial law, this is murder; for it is against Magna Carta.' Even in the case of mutinous soldiers there were doubts whether they could be executed according to martial law when not near to the enemy. See Donaghan, $n$ 39, 171. Cf. 178. See also the opinion of the lawyers and judges of the Council Board in July 1640 that 'martial law could not be executed in England but when an enemy is really near to an army of the king's.' See Clode, n 19, vol $1,23,56 \& 440-1$.

105 See Edmund of Woodstock, ODNB, n 52. Also, Hume, n 4, vol 2, 183.

${ }^{106}$ See Hale, n 56, 27. See generally, McBain, n 48, 836, n 213 and Finlason, n 19, 76. There seems little doubt that, in olden times, the sovereign had plenary power over military matters and that he could authorize others to execute it for him. The execution of persons such as the Earl of Lancaster in 1322 (when caught in open insurrection, see ns 108-11) would have been legitimized by Edward II (1307-27), who seems principally responsible for condemning him, on the basis the Earl had committed manifest treason (levying war, treated as treason prior to the Treason Act 1351). Further, Edward II would probably have asserted that the sovereign, as commander-in-chief, had the legal right to order the execution of rebels after battle on his own authority. It may be noted that Edward II's father, Edward I (1272-1307), had been a notable exponent of ordering the execution of rebels after battle, with scant, or no, trial. See Bellamy, n 53, n 44, ch 3, especially 40 (Scots rebellion of 1306). For an example of extensive Crown powers in military matters granted in later times, see a commission for the office of high constable granted to Earl Rivers in 1468. See also Tytler, n 30, 381-5; Hume, n 4,vol 4, 348 and Capua, n 19, 154.

107 Ibid.

${ }^{108}$ Coke, n 11, vol 3, 52-3 and 1 ST 41.Coke notes that the Earl 'being taken in an open insurrection, was by judgement of marshall law put to death.' See also McBain, n 48, 835, n 210 and Thomas, Earl of Lancaster, ODNB, n 52 ('on 22 March 1322, after what amounted to a show trial,
} 
tried before the sovereign and some other great men of the realm and condemned on the basis that his crime was notorious. He does not have appeared to have been given the opportunity to defend himself. ${ }^{109}$ In 1327, judgment against him was set aside - in part - because it was in time of peace and, also, he had not been judged by the correct legal procedure. ${ }^{110}$ Cockburn $\mathrm{CJ}$, in his address to the jury in $R v$ Brand and Nelson (1867), was dubious whether this was a case of martial law. More likely, it was one of summary trial before the king and some peers - as opposed to a required full trial before the lords in Parliament; ${ }^{111}$

- Roger Mortimer, Earl of March. The lover of Isabella - the mother of Edward III (1327-77) - he was brought before Parliament on 24 November 1330. Fourteen charges were preferred against him including 'accroaching royal power'. With no opportunity being given to defend himself, Mortimer was condemned on the basis that his crimes were notorious and executed. ${ }^{112}$ Judgment against him was reversed in Parliament in 1354.

These three cases - including that of Edmund, Earl of Kent - however, are rather special since they concern a common law crime (treason) rather than a specifically military one. Also, at the trial of the Earl of Lancaster, at least, a common law judge was present (Sir Robert Malberthorp). Thus, it is uncertain whether these are examples of civilians being tried under martial law in peacetime - or they were cases of judgment on the sovereign's record, the crime also being 'notorious." 113

Leaving aside these cases of famous individuals allegedly tried by martial law, as to the rank and file - in the case of peacetime rebellions in medieval times - it is likely that many civilians were tried and executed after the battle by some sort of military tribunal or pursuant to a royal commission which authorised the application of martial law to the rebels. ${ }^{114}$ As to major rebellions in the period 1381-1569, the following may be noted:

- Commissions were granted by Richard II (1377-99) to try rebels in the case of the Peasant's Revolt (Wat Tyler's Rebellion) (1381). ${ }^{115}$ It seems a large number of rebels were also executed extra-judicially after the rebellion, and an Act of Indemnity was issued to pardon the perpetrators; ${ }^{116}$

[the Earl of Lancaster] was executed at Pontefract'). See also Rolls of Parliament (RP) ii 3; Stephen, n 19, vol 1, 163 and Hume, n 4, vol 2 , 159-60 (the Earl was condemned by court martial).

${ }^{109}$ Bellamy, n 53, 51 'The Crown was using charges which had been employed by Edward I [1272-1307] to convict his enemies on his own record [ie. on his own testimony].' Also, 'It was the process against Thomas of Lancaster which first connected conviction on the royal record with trial for treason under the law of arms.' The Earl was also charged with accroaching royal power, ibid, 52 and 1 ST 43. See also Hale, n 9 , 121 (judgment coram rege et presentibus magnatibus). See also Capua, n 19, 154.

1101 ST 41 'when he was sentenced to death, was time of peace; in particular because, throughout the whole time aforesaid, the chancery and other places of the courts of the lord the king were open, and in them law was done to every one as it used to be done, nor did the same lord the king ever in that time ride forth with banners displayed.' Bellamy, n 53, 48 'In 1327 Henry, Earl of Lancaster argued successfully that men could only be convicted on the king's record if their treasons had been committed in time of war, which was when the king marched with his own banner displayed.' See also RP, n 108, ii 5. Bellamy notes that the use of the king's record in treason trials ended in 1327 save only where the crime was of fighting against the king in open war. See Bellamy, n 53, 158-9, 201, n 3. Cf. 170 (Duke of Clarence who was tried and executed for treason in 1478 on the testimony of this brother Edward IV (1461-83)).

${ }^{111}$ Brand \& Nelson, n 37, 26 'The Earl, it seems, was tried by the king and certain of his peers, instead of being tried, as he ought to have been, by his peers in Parliament. It was an irregular trial undoubtedly, but I question very much whether it was a case of martial law...At all events the attainder was reversed in the subsequent reign, on the ground that the whole proceeding had been quite irregular, the ordinary courts having been then open, before which the case ought to have been brought.' See also Rymer, n 33, vol 3, 936 and Hale, n 9,121-2.

$1121 \mathrm{ST} 51$ 'He was not brought to answer but condemned without hearing, and for that reason this judgment was reversed as erroneous'. See also Roger Mortimer, ODNB, n 52. 'The sentence was a foregone conclusion. Indeed, Mortimer was given no opportunity to answer the charges; he was declared guilty by the peers on the basis of the common notoriety of his crimes.' [ie. ill fame]. See also McBain, $\mathrm{n} 48,818, \mathrm{n} 66$ and 818, n 218; Stephen, n 19, vol 2, 246; Hume, n 4, vol 2, 184-5; Hale, n 9, 121 (judgment framed by the king, pronounced by special commissioners) and Bellamy, $\mathrm{n} 53,54$ (he was condemned by reason of his notoriety).

${ }^{113}$ These cases may also be early examples of attainder, where the sovereign and Parliament acted as a court, see Bellamy, n 53, 212. Also, McBain, n 48, 867-9.

114 These commissioners may have included senior military, or political, figures as well as a common law judge. For an early example of a trial for treason of a military commander by a royal commission see that of Andrew Harclay, $1^{\text {st }}$ Earl of Carlisle (c 1270-1323) on 3 March 1323; see Hale, $\mathrm{n}$ 9, 121.

${ }^{115}$ McBain, n 44, 100-3. See also Dobson, (1970), ch 7 and Dunn (2004), ch 7. One of the Commissions granted by Richard II was to Thomas, Earl of Buckingham (youngest uncle to Richard II (1377-99)) and to Tresilian CJ, see Dunn, 168 and Bellamy, n 53, 150. For commissions of martial law in 1398, 1414 \& 1471, issued to deal with rebels see Bellamy, n 53, 150. 
- In the case of a large riot led by Tom Cheyney (Cheyne) in 1450, a commission headed by the Earl of Wiltshire was sent to Kent to judge the rioters. It is likely that many were also killed extra-judicially; ${ }^{117}$

- Cockburn CJ noted the practice - in the reigns of Henry IV (1399-1413) and Henry VI (1422-71) of executing prisoners just after a battle without any form of trial; ${ }^{118}$

- Other large rebellions - such as those of the Lollards (1411 and 1431), Jack Cade's Rebellion (1450), ${ }^{119}$ rioting in Yorkshire (1489), the Cornish Rebellion (1497), the Lincolnshire rebellion (1536), the Pilgrimage of Grace (1536), Kett's rising in East Anglia (1549), Wyatt's Rebellion (1554) and the rising in the North (1569) - were usually treated as rebellions in which banners (standards) were raised against the sovereign. Hence, the rebels were held to have committed treason (in levying war against the sovereign) with the common law courts often trying the main offenders. ${ }^{120}$ That said, it is also likely many rebels were also dispatched pursuant to martial law.

In conclusion, it is likely that many civilians caught up in these rebellions - whether in (or near) places of armed resistance or just after the fighting - were summarily executed under martial law, including those executed by ad hoc (or drum head) military tribunals. In Tudor times, the picture is clearer. Edward VI (1547-53), Mary (1553-8) and Elizabeth I (1558-1603) all issued proclamations in which martial law was imposed on civilians. Such impositions of martial law were mainly at times of rebellion or with the threat of foreign invasion hanging over the country. However, Elizabeth I had a particular dislike of 'vagabonds' and 'vagrants ${ }^{\text {'21 }}$ and she was happy to issue proclamations for their being tried by martial law, as opposed to the normal common law process. A list of these proclamations is as follows:

- Edward VI. A proclamation of Edward VI (1547-53) issued in July 1549, ordered martial law to be applied against those who rioted against enclosures; ${ }^{122}$

- Edward VI. Cockburn CJ in his address to the jury in $R v$ Brand and Nelson (1867) refers to a proclamation in 1552 in which the king gave a commission to John, Earl of Bedford to try rioters according to martial law; ${ }^{123}$

- Mary. The historian Hallam maintains that Mary (1553-8) had executed some of those taken in Wyatt's rebellion in 1554 by martial law. ${ }^{124}$ In 1558 , Mary issued a proclamation imposing martial law on those who imported heretical, or seditious, works; ${ }^{125}$

\footnotetext{
116 Brand \& Nelson, n 37, 26 refers to 5 Ric c 6 (1381, rep)(the King's pardon to those who repressed and took revenge of his rebels). See also Tytler, n 30, 49; Finlason, n 19, 76-7 and Capua, n 19, 154-5.

117 On 26 January 1450, Cheyney and others rebelled, attacking an abbey in Canterbury. Cheyney was later executed for treason. See McBain, n 44, 100-3. Also, Kaufman (2009). For the use of commissions to try persons under martial law in the reign of Henry VII (1485-1509) see Baker, n 56, 216-7.

118 Brand \& Nelson, n 37, 27. Cockburn CJ also refers, 28-9, to the practice of Henry VII (1485-1509) after the battle of Stoke in June 1487 of holding commissions and martial law tribunals in order to execute rebels for treasons but then offering them a way out by fines and ransom, a practice Cockburn CJ called 'utterly illegal'. See also Hume, n 4, vol 3, 19 (Stoke) and 45 (execution of Perkin Warbeck prisoners in July 1495). See also Bellamy, n 53, 215 re the military style execution of Richard Woodville, 1st Earl Rivers, Sir Richard Grey (nephew to Earl Rivers) and Sir Thomas Vaughan in 1483, likely on the orders of Richard III (1483-5). See ODNB, n 52 for biographies of these people.

119 Finlason, n 19, $77 \&$ 83. Also, Lyle (1950). On 1 August 1450, a commission was appointed to try Cade's rebels (at least 8 rebels were condemned and executed). A commission was also given to the Duke of York and there were 41 executions (the so-called Harvest of Heads). ${ }^{120}$ See generally, McBain, n 44, 99. Also, Baker, n 56, 217 (martial law used against rioters in the Lincolnshire rebellion in October 1536 (various ringleaders being hanged) and the condemnation of 74 prisoners without jury trial in 1537). See also Hume, n 4, vol 3, 235-9 and Capua, n 19, 160-7 (as well as texts cited in 163, n 45). For the Lollards, see Bellamy, n 53, 107 \& 150. Capua, n 19, 161 thought that some 80 people were executed under martial law in the aftermath of the Pilgrimage of Grace (1536).

${ }^{121}$ OED, n 20. (vagabond) 'One who has no fixed abode or home, and who wanders about from place to place; spec [especially] who does this without regular occupation or obvious means of support; an itinerant beggar, idle loafer, or tramp; a vagrant'. Also, 11 Hen VII (1495) c 2 (vagabonds). See also Capua, n 19, 153 'Beginning in the 1550 's...the Crown began to claim the authority to expand the hitherto carefully circumscribed jurisdiction of martial law beyond situations of war or open rebellion and into territory which had been the exclusive domain of the criminal law.'

${ }^{122}$ Hughes \& Larkin, $n$ 60, vol 1, 475-6 (authority and order of law martial).

${ }^{123}$ Brand \& Nelson, n 37, 34. Cockburn CJ refers to Strype (1822), vol 4, 31, 207, although he was unable to locate the commission as such and it does not appear to have been acted on. The reference is to John Russell, $1^{\text {st }}$ Earl of Bedford (c. 1485-1554/5). See also vol 3, 267 (martial law in 1549 against those who tear down enclosures) also referred to in Brand \& Nelson, n 37, 32. See also Hughes \& Larkin, n 60, vol 1, 475-6; Hume, n 4, vol 3, 356-7 \& vol 4, 347 and Finlason, n 19, 87.
} 
- Elizabeth I - 1558-95. In June 1558, a proclamation of Elizabeth I (1558-1603) imposed martial law on the possessors of heretical, or seditious, books - although this does not seem to have been enforced. ${ }^{126}$ In 1569, Maitland refers to a commission appointed after the insurrection of the northern earls, when 'six hundred persons were, it is said, executed by the Earl of Sussex. ${ }^{127}$ In July 1588 (when there was a threat of invasion from the Spanish Armada), Elizabeth I issued a proclamation declaring those who issued traitorous libels (or papal bulls) against her were to be proceeded against by martial law; ${ }^{128}$

- Elizabeth I - 1595-1603. In November 1589, a proclamation of Elizabeth I placed vagrant soldiers under martial law ${ }^{129}$ and, one in November 1591, placed vagrants under martial law. ${ }^{130}$ In July 1595, after riots in London, Elizabeth granted a commission to Sir Thomas Wilford to try, and execute, rioters according to martial law - although it seems this was not utilised in practice. ${ }^{131}$ In September 1598, London vagabonds were placed under martial law and a provost marshal was appointed. He was empowered to apprehend 'all such as shall not be readily reformed and corrected by the ordinary officers of justice, and them without delay to execute upon the gallows by order of martial law. ${ }^{132}$

Maitland refers to commissions issued by James I (1603-25) in 1617, 1620 and 1624 which empowered commissioners to try civilians by martial law - even those who had been guilty of ordinary felonies. ${ }^{133}$ It is unclear whether many people were executed pursuant to these commissions. In respect of these, Maitland states:

There can, I think, be no doubt that, according to the opinion of lawyers of the time, such commissions were illegal. The government may put down force by force - but when there is no open rebellion, or when the rebellion is suppressed, it has no authority to direct the trial of prisoners, except in the ordinary courts and according to the known law of the land. As to what was this 'law called martial law' we know little, and probably there is little to be known; it means an improvised justice executed by soldiers. ${ }^{134}$

\footnotetext{
${ }^{124}$ Hallam, n 5, vol 1, 240-1. See also 43 (proclamation of 1557). See generally Loades (2001).For a threat by James I to invoke martial law against poachers in the royal forests, see 170. See also Baker, 56, 217-8.

${ }^{125}$ Brand \& Nelson, n 37, 85. See also Hughes \& Larkin, n 60, vol 2, 90-1 and Tytler, n 30, 50. Capua did not think it likely there were many executions under this proclamation, see Capua, n 19, 166.

${ }^{126}$ Hughes \& Larkin, n 60, vol 2, 90-1. Those finding such books who did not forthwith burn them without showing or reading the same to any other person 'shall in that case be reputed and taken for a rebel, and shall without delay be executed for that offense, according to the order of martial law.' When Peter Burchell (a fanatical puritan) wounded the famous seaman Capt Hawkins (by way of transferred malice, he sought to kill Sir Christopher Hatton), Elizabeth I wanted him executed immediately by way of martial law. She was dissuaded. See Hallam, n 5, vol 1, 241. See also Brand \& Nelson, n 37, 85 (in terrorem). See also Hume, n 4, vol 4, 347.

${ }^{127}$ Maitland, n 17, 267. See also Hallam, n 5, vol 1, 243, Forsyth, n 5, 555 (600 persons executed between 2-20 January 1569 under Sir George Bower, Provost Marshall) and Hume, n 4, vol 4, 347 (he says 800). The Earl of Sussex was Thomas Radcliffe (1526/7-83), $3^{\text {rd }}$ Earl, see ODNB, n 52. See also Thornton (2010), 92; Stephen, n 19, 210 and a Report of the Case of the Queen v Edward John Eyre for High Crimes and Misdemeanours alleged to have been committed by him in his office as Governor of Jamaica (ed Finlason, 1867) 71, per Blackburn J. For a commission of 1585 to execute according to marshal law, see Bellamy, n 5, 231.

${ }^{128}$ Ibid. See also Hughes \& Larkin, n 60, vol 3, 13-7 and Hallam, n 5, vol 1, 241. See also the appointment of the Marquis of Winchester a Lieutenant of the Realm with power to impose martial law, Hughes \& Larkin, n 60, vol 2, 86-8.

${ }^{129}$ Hughes \& Larkin, n 60, vol 3, 46-8. See also, 32-4 (army deserters).

${ }^{130}$ Ibid, vol 3, 96-7.

131 Ibid, 143. Hallam, n 5, vol 1, 242 'This peremptory style of superseding the common law was a stretch of prerogative without an adequate parallel, so far as I know, in any former period.' Wilford was appointed provost-martial with authority to seize rebellious persons and, in the presence of the magistrates, to execute them openly on the gallows. His commission was withdrawn in September 1595. See also Archer (1991), 1-2. For Sir Thomas Wilford (c. 1530-1610), see ODNB, n 52. See also Brand \& Nelson, n 37, 39-41 ('they were not put to death by martial law; they were brought before the ordinary tribunals of the country; and punished according to the nature of their offences.'). See also Brodie (1866), vol 1, 165; Tytler, n 30, 51-2; Hume, n 4, vol 4, 348 and Finlason, n 19, 87-8. See also Capua, n 19, 170.

132 Hughes \& Larkin, n 60, vol 3, 196-7. See also a proclamation of 15 February, 1601. Ibid, 232-3.

133 See also Capua, n 19, 171. Maitland, n 17, 267, 279-80, 325-9. See, in particular, 279 (Commission of December 1624). For details of these commissions see Stephen, n 19, vol 1, 208-10 and Forsyth, n 5, 553-4. Also, Brand \& Nelson, n 37, 41-2 (Commission to Lord Compton as Lord Lieutenant in Wales) to 'fight all enemies, traitors and rebels from time to time, and them to invade, resist, suppress, subdue, slay, kill and put to execution of death by all ways and means from time to time by your discretion.' Cockburn CJ regarded such a commission as illegal, 43. See also Clode, n 19, vol 1, 422-3 and Finlason, n 19, 86.

${ }^{134}$ Maitland, n 17, 267. For the pre-emptory order of James I (1603-25) to hang a pickpocket taken in the fact without trial (James I was dis-suaded from this), see Hallam, n 5, vol 1, 290. And, for a threat by James I, to invoke martial law against poachers in the royal forests, see 170
} 
Did legal writers in those times have doubts as to the legality of the actions of the Crown in imposing martial (military) law over civilians? Thomas Smith in his De Republica Anglorum, written c. 1562-5 expressed his own misgivings:

In war time, and in the field the prince has also an absolute power, so that his word is a law, he may put to death, or to other bodily punishment, which he shall think so to deserve, without process of law or form of judgment.

This has been sometime used within the realm before any open war in sudden insurrections and rebellions, but that was not allowed of [i.e. assented to by] wise and grave men, who in that their judgment had consideration of the consequence and example, as much as of the present necessity, especially, when by any means the punishment might have been done by order of law.

This absolute power is called martial law, and ever was and necessarily must be used in all camps and hosts of men, where the time nor place do suffer the variance of pleading and process, be it never so short, and the important necessity requires speedy execution, that with more awe the soldier might be kept in more straight obedience, without which never no captain can do anything valuable in the wars. ${ }^{135}$ (Italics supplied and wording divided for ease of reference).

In conclusion - particularly in Tudor times - the Crown extended the concept of martial law to cover civilians caught up in rebellions. Also, to vagrants and vagabonds. Doubtless, this was an unwarranted extension of a prerogative once limited to the Court of Chivalry and the field of battle. However, it was (see below) the wide ranging commissions of martial law of Charles I (1625-49) which provoked Parliament into making martial law in peacetime illegal pursuant to the Petition of Right 1627.

\subsection{Commissions Imposing Martial Law - 1625-7}

The Petition of Right 1627, s 7 (still extant) refers to commissions having been issued under the great seal for proceedings according to martial law and people being executed thereunder. ${ }^{136}$ These commissions were issued by Charles I (1625-49) in the period 1625-7. ${ }^{137}$ The background to this is that, in May 1625, some 8,000 soldiers were levied to be employed in the service of Frederick V - the Elector Palatine (James I's son - in - law) - and to rendezvous at Plymouth on 25 May 1625. A further 2,000 soldiers were levied to rendezvous for service in Hull. The historical commentator Rushworth states:

The remembrance of the late violence committed by count Mansfield's army in their passage to Dover, ${ }^{138}$ occasioned a proclamation to repress and prevent the like attempts of soldiers, as they now passed through the counties to the places of rendezvous, threatening the offenders with the strictest proceedings against them, for an example of terror; and straitly commanding the officers, who have charge of their conduct, for the removing of all occasions and pretences of disorders, to see their companies duly paid, and provided of all necessaries and to be always present with them, and carefully to conduct them from place to place.

In like manner to prevent their outrages, when they should come to Plymouth, or the parts adjoining, $a$ commission was sent, empowering persons of trust, upon any robbery, felony, mutiny, or other misdemeanours (punishable with death by martial law) committed by the soldiers, or other dissolute persons joined with them, to proceed to the trial and condemnation of all such delinquents, in such summary course and order, as used in armies in time of war, according to the law martial; and to cause

\footnotetext{
${ }^{135}$ Smith (1562-5), 85-6. There is no doubt that, in the early Stuart period, under pressure from James I (1603-25) and Charles I (1625-49), the courts allowed an increasingly inflated view of the Crown prerogative. See eg. Holdsworth, n 19, 124 referring to the Ship Money Case (1624) 3 ST at 1234 per Finch CJ 'The opinion of the majority of the judges was in favour of allowing to the Crown a power to proclaim martial law whenever the country was in danger; and of the existence of that danger they held that the Crown was the sole judge.'

${ }^{136} 3$ Cha 1 (1627) '... of late time divers commissions under your majesty's great seal have issued forth, by which certain [persons] have been assigned and appointed commissioners with power and authority to [proceed] within the land according to the justice of martial law against such soldiers or mariners or other dissolute [persons] joining with them as should commit any murder robbery felony mutiny or other outrage or misdemeanor whatsoever, and by such summary course and order as is agreeable to martial law and as is used in armies in time of war to proceed to the trial and condemnation of such offenders, and to cause them to be executed and put to death according to the law martial. By [pretext] whereof some of your majesty's subjects have been by some of the said commissioners put to death...' The wording in brackets was inserted in Halsbury's Statutes, to add clarification.

${ }^{137}$ Charles I (1625-49) clearly followed the commissions of his father. See n 133. See also Clode, n 19, vol 1, 17-9.

${ }^{138}$ Ernst Graf von Mansfield (c. 1580-1626), a German military commander and mercenary during the early years of the 30 years war. See also Hume, n 4, vol 5, 7. In January 1625, Mansfield sailed from Dover with a motley army.
} 
execution to be done in open view, that others may take warning and be kept in due obedience. ${ }^{139}$ (italics supplied and wording divided for ease of reference)

A further commission of martial law was issued in December 1625 when there was a threat of invasion from Spain. Thus, on 28 December 1625, Charles I (1625-49) issued a commission to Lord Wimbleton (lord marshal) and to Sir William St Leger (sergeant major of the Army) empowering them to use martial law against public enemies, traitors etc. ${ }^{140}$ The commission stated that - Charles I wanting not to disband his soldiers returning from Cadiz and intending to billet them in Plymouth and its surrounds ${ }^{141}$ - they would be subject to martial law:

and to the end that all disorders and outrages, to the disturbance of our peace and the prejudice of our loving subjects, may be timely prevented, we, being more desirous to keep our people from doing mischief than to have cause to punish them for doing the same; have, of the special trust and confidence we have reposed in your approved wisdoms and fidelities, appointed you to be our commissioners, and by this presents do give unto you, or any three or more of you, full power and authority in all places within our said counties of Devon and Cornwall and either of them, as well within the said town of Plymouth or any other town or liberty or place as without, within our said counties of Devon and Cornwall or either of them,

to proceed according to the justice of marshall laws against such soldiers or other dissolute persons joining with them or any of them, as during such time that any of our said troops or companies of soldiers shall remain or abide thereabouts, and not be transported thence, shall within any the places or precincts aforesaid at any time after the publication of this our commission, commit any robberies, felonies, or mutinies, or other outrages or misdemeanours, which by martial law should or ought to be punished with death, and by such summary course and order as is agreeable to marshall law, and is used in armies in time of wars, to proceed to the trial and condemnation of such delinquents and offenders, and them to cause to be executed and put to death according to the law marshall for an example of terror to others, and to keep the rest in due awe and obedience. ${ }^{142}$ (italics supplied and wording divided for ease of reference).

A further Commission was issued on 4 October 1626 after the Forced Loan of 1626 (in which Charles I billeted soldiers on citizens who failed to lend him money). ${ }^{143}$ This commission was similar to that of December $1625 .{ }^{144}$

\footnotetext{
${ }^{139}$ Rushworth, n 25, vol 1, 168.

${ }^{140} \mathrm{Ibid}$, 'And for the defence of this realm, threatened with a powerful invasion, extraordinary commissions were given to the lords lieutenants of the several counties, to muster the subjects of whatsoever degree or dignity, that were apt for war, and to try and array them, and cause them to armed according to the degrees and faculties, as well men of arms as other horsemen, archers and footmen, and to lead them against publick enemies, rebels, and traitors, and their adherents, within the counties of their lieutenancy, to express, slay, and subdue them, and to execute martial law, sparing and putting to death according to discretion. And in case of invasions, insurrections, rebellions, and riots, without the limits of their respective counties, to repair to the places of such commissions, and, as need required, to repress them by battle, or any forcible means or otherwise, either by the law of this realm, or the law martial' (spelling modernized and italics supplied). For the text of this Commission see Rymer, n 33, vol 18, 254 and Samuel, n 27, 421. See generally, McBain (2011c) 97. See also Boynton (1964) 255-84 and Boynton (1962), 255-84. Lord Wimbelton (Sir Edward Cecil, 1572-1638) was appointed commander-in-chief of the ill fated expedition to Cadiz, see Rushworth, n 25, 195-7 and ODNB, n 52. See also William St Leger (d. 1642), ODNB, n 52 and Hume, n 4, vol 5, 11.

${ }^{141} \mathrm{Ibid}$. 'Whereas upon the return of our fleet, we have already directed that none of the soldiers employed in that service, and which shall return in any of those ships, shall be disbanded or depart from their colours, but shall continue under the command of those under whom they then served, we having present occasion to use their services again, and yet we shall be enforced for a time to lodge and billet the said soldiers in several places in and about our town of Plymouth and in our counties of Devon and Cornwall, where with most convenience for the soldiers and the least trouble to the country it may best be performed, until we shall have opportunity to employ them, which we intend to do with all expedition...' (spelling modernized).

${ }^{142}$ Ibid.'To which purpose our will and pleasure is that you cause to be erected such gallows and gibbets, and in such places within the said counties or either of them, as you shall think fit, and thereupon to cause the same offenders to be executed in open view, that others may take warning thereby to demean themselves in such due order and obedience as good subjects ought to do, straitly charging and commanding all mayors, sheriffs, justices of peace, constables, bailiffs and other officers, and all other our loving subjects whatsoever, upon their allegiance to us and our crown, to be aiding and assisting to you, or such three or more of you as aforesaid in the due execution of this our royal commandment; and this presents shall be unto you and every of you a sufficient warrant and discharge for the doing and executing, and causing to be done and executed, all and every such act and acts, thing and things, as any three or more of you as aforesaid shall find requisite to be done concerning the premises.' (spelling modernized)

${ }^{143}$ Ibid, 419. 'To the imposition of loan was added, the burden of billeting of soldiers formerly returned from Cadiz, and the moneys to discharge their quarters were for the present levied upon the country, to be repaid out of sums collected upon the general loan. The companies
} 
These commissions provoked the wording in the Petition of Right 1627 which sought to end such Crown attempts to apply martial law to civilians. Section 8 of the Petition stated:

And that the aforesaid commissions for [proceeding] by martial law may be revoked and annulled. And that hereafter no commissions of like nature may issue forth to any [person] or [persons] whatsoever to be executed as aforesaid, lest by colour of them any of your majesty's subjects may be destroyed or put to death contrary to the laws and franchise of the land. (spelling modernised). ${ }^{145}$

That said, even after the Petition of Right 1627, it seems Charles I issued commissions of martial law - in 1637 and 1639. ${ }^{146}$ It would not appear that either Charles II (1660-85) or James II (1685-8) issued commissions of martial law (martial law was imposed on the military, however). ${ }^{147}$ After the Glorious Revolution, the Mutiny Act 1688 enacted to punish mutiny and desertion - stated in its Preamble:

No man may be forejudged of life or limb, or subjected to any kind of punishment by martial law, or in any other manner than by the judgment of his peers, and according to the known and established laws of this realm. ${ }^{148}$ (italics supplied)

This wording - repeated in later Mutiny Acts with the addition of the words 'in peace' - ${ }^{149}$ re-states Magna Carta, chapter $29^{150}$ as well as confirms the Petition of Right 1627, s 8. As it was, no commissions of martial law were issued by the Crown after 1688 (at the latest). Halsbury notes:

the issue of commissions of martial law has long been discontinued. ${ }^{151}$

Finally, Lord Halsbury LC in Exp Marais (1902) stated:

The framers of the Petition of Right knew well what they meant when they made a condition of peace the ground of the illegality of unconstitutional procedure. ${ }^{152}$ (italics supplied)

In conclusion, any Crown prerogative to impose martial law on civilians in peacetime was made illegal by the Petition of Right 1627, s 8 (still extant). Thus, any abolition of the Crown prerogative to this extent will simply confirm present law.

\footnotetext{
were scattered here and there in the bowels of the kingdom, and governed by martial law: the king gave commissions to the lords lieutenant and their deputies, in case of felonies, robberies, murders, outrages, or misdemeanours, committed by mariners, soldiers, or other disorderl;y persons joining with them, to proceed according to certain instructions, to the trial, judgment, and execution of such offenders, as in time of war; and some were executed by those commissions.' (spelling modernised). See also Forsyth, n 5, 193.

${ }^{144}$ Rymer, n 33, vol 18, 763 'to proceed according to the justice of martial law against such soldiers or mariners, or other dissolute persons joining with them or any of them, as within the said county [of Kent] or any part thereof, shall at any time, after the publication of this our commission commit any robbery, felony, mutiny, or other outrage or misdemanour, or which shall withdraw themselves from their places of service or charge as aforesaid, or shall be found within the said county or any part thereof, which by the martial law should or ought to be punished with death, and by such summary course' etc. See also Proclamation of 7 October 1626, 765.

145 The wording in brackets was inserted in Halsbury's Statutes, to add clarification. See also Rushworth, n 25, 569 (speech of Glanvile MP of 23 May 1628 in a full Committee of both Houses of Parliament) 'The fourth and last [provision in the Petition of Right 1627] aimeth at redress touching commissions, to proceed to the trial and condemnation of offenders, and causing them to be executed and put to death by the law martial, in times and places, when and where, if by the laws and statutes of the land they had deserved death, by the same laws and statutes also they might, and by none other ought to be adjudged and executed.' See also 558 and Blackstone, n 12, vol 1, 400 'And the petition of right enacts...that no commission shall issue to proceed within this land according to martial law.' See also Hallam, n 5, vol 1, 389.

${ }^{146}$ Forsyth, n 5, 193, to the Earl of Warwick in 1637 (going with the fleet to the West Indies) and in 1639 (to the Earl of Northumberland). See also one of the Commonwealth of 1653,194 . See also Clode, $\mathrm{n} 67,6-8$.

${ }^{147}$ See Articles of War governing the military, Clode, n 19, vol 1, 76-7, 475-6 (Monmouth rebellion). For military codes of $1672 \& 1686$, see Holdsworth, n 55, vol 6, 226. See also Clode, n 67, 15-9.

1481 Will \& Mar c 5 (1688). See also Samuel, n 27, 138; Robertson, n 85, 110; Tytler, n 30, 18 and Clode, n 19, vol 1, 143 \& 499-500.

$149 \mathrm{viz}$. no man can be forejudged of life and limb, or subjected to any punishment within this realm by martial law, in time of peace.' Stephen, n 19, vol 1, 213 'the words 'in peace' which were not in the first Mutiny Act, probably meant that standing armies and military courts were, in time of peace, illegal, except in so far as they were expressly authorized by Parliament.'

150 See $\mathrm{n} 103$.

${ }^{151}$ Halsbury, n 13, vol 8(2), para 821, n 1 . Also, 'The Crown may not issue commissions in time of peace to try civilians by martial law...'

${ }^{152}$ [1902] AC 109 at 115.
} 


\section{Martial Law - Military Law Imposed on Civilians in Time of Great Riots or Rebellion}

Halsbury notes that the ambits of the Petition of Right 1627 are obscure and that they can be made to bear a wider interpretation. ${ }^{153}$ Thus, it was never clear whether the Petition of Right 1627 was also intended to make it illegal to exercise the Crown prerogative to declare martial law during:

- Internal insurrection - such as in the case of great riots or rebellion; or

- War time.

Thus, Anson (in its $4^{\text {th }}$ edition, in 1935) states:

The Petition of Right, 1628, negative the legality of such action in peace in undoubted terms, leaving it arguable whether it contemplated such law as valid in the case of war. ${ }^{154}$

The historical position as to riots and rebellion will now be considered. However, the conclusion may be stated at the outset. By 1714 - as a result of the Riot Act 1714 - it was no longer necessary in any case to apply martial law to rioters. Further, in England, after 1688 there were no major rebellions in which martial law was needed (in the Jacobite rebellions of 1715 and 1745, the normal courts dealt with rebels). Martial law was still applied, however, in respect of rebellions in various colonies. But, because of the uncertainly as to the lawfulness of exercising such a Crown prerogative, invariably Acts of Indemnity were subsequently passed by Parliament to indemnify the military for their actions. The position is as follows:

\subsection{Martial Law: Riots and Rebellions up to 1745}

The position of Coke, Hale and Blackstone was clear:

- The Crown had no prerogative to impose martial law - even during great riots and rebellion - while the king's courts remained open, since it was for the king's courts to judge, and punish, criminal behaviour; ${ }^{155}$

- In particular, it was contrary to the Petition of Right 1627 to impose martial law on civilians while these courts were open. ${ }^{156}$ Indeed, these legal writers believed it was murder to execute a civilian on the orders of a military court or tribunal if the courts were open (i.e. during peacetime); ${ }^{157}$

${ }^{153}$ Halsbury, n 13, vol 8(2), para 821.

${ }^{154}$ Anson, n 20, vol 2, pt 1, 315. Holdsworth, n 55, 576 'The Petition of Right did not however deny that the constable and marshal's court had jurisdiction over soldiers in time of war. It was a declaratory act; and it is clear from the exposition of contemporary lawyers that it was not intended to abolish its legitimate jurisdiction.' Dodd, n 19, p 153 'in the Petition of Right nothing is in express terms either affirmed or denied as to what the king may do in time of war.' Bradley \& Ewing, n 16, 632 'the Petition of Rights 1628 contains a prohibition against the issue by the Crown of commissions of martial law giving the army powers over civilians, at least in peacetime, and the meaning of this prohibition is far from clear today.' See also Brand \& Nelson, n 37, 66 and a Report, n 127, 73, per Blackburn J 'I think... it would be an exceedingly wrong presumption to say that the Petition of Right, by not condemning martial law in time of war, sanctioned it; still it did not in terms condemn it.' See also Forsyth, n 5, 203 and Phillips \& Jackson, 398. Capua, n 19, 172 'The framers of the Petition had no quarrel with martial law being exercised in war time among soldiers in the field, nor in the event of rebellion in England.' Also, 171. See also Clode, n 19, vol 2, 156 (Petition of Right only restrains the Crown in time of peace).

${ }^{155}$ Coke, n 11, vol 2, s 412 'when the courts of justice be open, and the judges and ministers of the same may by law protect men from wrong and violence, and distribute justice to all, it is said to be time of peace. So, when by invasion, insurrection, rebellions, or such like, the peaceable [probably, the peace of the] courts of justice is disturbed and stopped, so as the courts of justice be as it were shut up, et silent leges inter arma, [and amidst the clash of arms the laws are silent] then it is said to be time of war.' (spelling modernized). Also 'Time of peace is when the Chancery and other King's courts are open, whereby the law may be done to everyone in the usual way' (translated from the latin) and 'Whether a land is at war or not ought naturally to be adjudged by the records of the king and of those who keep and govern the king's courts by the law of the land, but not in any other way.' (translated from the latin). Holdsworth, n 55, vol 1, 576 'It was a time of peace if the central courts were open, and the sheriff could execute the king's writ.' See also Rushworth, n 25, pt 11, vol 2, App 79, 81 and Clode, n 19, vol 2, 158 (quoting Coke 'When the courts are open, martial law cannot be executed.')

${ }^{156}$ Coke, Hale and Blackstone's perception that soldiers were also governed by the general law and that martial law could only apply on the battle field (or, possibly, near it) was against the backdrop of England not having a (legitimate) standing army prior to the Glorious Revolution. It was only in 1688 - with the first Mutiny Act - that the legitimacy of a standing army became recognized (albeit only partly so, since the Mutiny Act had to be renewed annually). With the presence of a standing army, came the acceptance that the armed forces were subject to their own body of law (military law) during war, and peace, time.

${ }^{157}$ Brand \& Nelson, n 37, 59 per Cockburn CJ, 'It is hardly conceivable that such authors as these, when writing on the laws of England, and carefully enumerating every species of law obtaining within the kingdom, would, when they came to speak of martial law, have been wholly silent as to the power of applying it to the trial and punishment of civilians in times of civil disturbance and insurrection, if any power so 
- The fact that - in the past - the Crown had purported to impose martial law on civilians during peacetime - by virtue of commissions and proclamations - was the very reason why these legal writers deprecated martial law and declared it to be 'no law'.

Thus, to the time of Blackstone at least (ie. 1765) the legal position as to the imposition of martial law, as stated by these legal writers, was clear:

(i) Martial law only covered civilians on the battlefield (or close to) ${ }^{158}$ and not away from it. ${ }^{159}$ Only the former was war time - whether the war was against a foreign, or an internal, enemy;

(ii) Martial law could not be imposed in peacetime. This included all riots and rebellions unless (i) applied (i.e. martial law could be applied against rebels in open armed resistance).

A similar perception in the $19^{\text {th }}$ century was that of Cockburn CJ in $R v$ Nelson \& Brand (1867). ${ }^{160}$ In that case a rebellion in Jamaica (a settled colony) occurred in October 1865 and a British subject and civilian called Gordon thought to be one of the ringleaders - was apprehended by Governor Eyre. He was later executed for treason by a military court assembled by order of one Colonel Nelson and presided over by one Lieutenant Brand. It was argued that this court had no jurisdiction ${ }^{161}$ and that - even if it had - such had been exercised corruptly. In his address to the jury, Cockburn CJ reviewed at length the history of martial law. He was careful to distinguish between cases where rebels (civilians) were put to death on the battlefield as the enemy (effectively, during war time) and where civilians were put to death not on the field of battle - which he treated as martial law as such. ${ }^{162}$ Even in the case of rebel soldiers, Cockburn CJ noted a practice that prevailed up to Tudor times of executing prisoners after a battle was over, which he took to be barbarous and illegal. He concluded:

if it be true that you can apply martial law for the purpose of suppressing rebellion, it is equally certain that you cannot bring men to trial for treason under martial law, after a rebellion has been suppressed. ${ }^{163}$ (italics supplied)

Thus, Cockburn CJ clearly limited martial law to the battlefield and all attempts by the Crown to extend it whether by proclamation or commission - he adjudged (rightly, it is asserted) to be illegal. Cockburn CJ also reviewed many of the commissions for martial law granted by the Crown granted in the reigns of Edward VI (1547-53), Mary (1553-8), Elizabeth (1558-1603) and James (1603-25); he regarded them also as illegal. He also referred to the Petition of Right 1627 and concluded:

certain it is that from that time [i.e. 1627] martial law has never been attempted to be exercised in the realm of England by virtue of the prerogative. ${ }^{164}$

applying it had in their opinion existed.' Cockburn CJ also quotes Rolle (later CJ) 'If a subject be taken in rebellion, and be not slain at the time of his rebellion, he is to be tried after by the common law.' See also Rushworth, $\mathrm{n} 25$, vol 3, 79 and Forsyth, $\mathrm{n} 5,211$. See also $R v$ Eyre (n 127), at 74 per Blackburn $\mathrm{J}$.

${ }^{158}$ Forsyth, n 5, 207. At 213 'there is no legal necessity for any form of trial at all when the rebel is met with arms in his hands, flagrante bello, for he may be killed on the spot. But if, instead of being killed in open resistance, he were to be arrested, the gravest responsibility would be incurred if he were to be put to death without some form of trial, and analogy would suggest a trial by court martial.'

${ }^{159}$ Hale (1820), 13 'The king may punish his subjects by martial law during such insurrection or rebellion, but not after it is suppressed.' Where a sheriff in Tipperary, Ireland, flogged a man at a time of rebellion in 1798 but there was no pretence that the man had been involved in same, he was liable in damages. See Wright v Fitzgerald (1799) 27 ST 765. See also Stephen, n 19, vol 1, 215-6; Bradley \& Ewing, n 16, 634-5 and Forsyth, n 5, 560 .

${ }^{160}$ Brand \& Nelson, n 37. See also Forsyth, n 5, 555-63.

${ }^{161}$ Governor Eyre, with the concurrence of a council of war, proclaimed part of Jamaica to be under martial law on 13 October 1865 but not the capital Kingston, where Gordon was seized after he surrendered himself to military forces on 17 October. Gordon was taken into custody by Governor Eyre on 20th October. He was executed on $23^{\text {rd }}$ October, after a trial on the 21st.The military court comprised Lieutenant Brand RN, (President), Lieutenant Errington RN and Ensign Kelly of the $4^{\text {th }}$ West India Regiment. On 9 November, a local Act of Indemnity was enacted (29 Vict c 1). On 6 February 1867 an information was laid before the Chief Magistrate at Bow Street for the arrest of Nelson on a charge of wilful murder. An indictment against him was presented to the Grand Jury on 16 April 1867. After the charge of Cockburn CJ, the Bill was thrown out. An indictment presented against Governor Eyre on 2 June 1868 was also thrown out by a Grand Jury, after the charge of Blackburn $\mathrm{J}$ (see $\mathrm{n}$ 127). See also 4 LR (QB) 242 and Clode, n 19, vol 2, 492-7.

162 Brand \& Nelson, n 37, 25 'We are not dealing with the case of rebels killed on the field of battle, or put to death afterwards without any trial at all. A rebel in arms stands in the position of a public enemy, and therefore you may kill him in battle as you might kill a foreign enemy...we must not confound [this] with martial law applied to civilians.'

${ }^{163}$ Ibid, 29 'the only justification of it [trial by martial law after a rebellion was over] is founded on the assumption of an absolute necessity a necessity paramount to all law, and which, lest the commonwealth should perish, authorizes this arbitrary and despotic mode of proceeding.' 
While this was true - as regards England post-1627 (with some exceptions) ${ }^{165}$ - martial law was sought to be exercised in some colonies and in Ireland up to 1920, see 5. Cockburn CJ concluded that:

no such thing as martial law has ever been put in force in this country against civilians, for the purpose of putting down rebellion. ${ }^{166}$ (italics supplied)

This is a bit of a tall statement. It is only true if one treats as illegal all executions of civilians pursuant to proclamations, commissions etc prior to 1688 (ie. prior to the first Mutiny Act 1688) - including the execution of vagrants and vagabonds in the time of Elizabeth. ${ }^{167}$ That said, it should also be remembered that, in many of these rebellions where civilians were executed other than on the field of battle, often a civil judge was present and the crime was treason. Therefore, the law being enforced (at least, claimed to be enforced) was legislation - the Treason Act 1351.

- Thus, civilians who were rebelling were hung, drawn and quartered (or, more speedily, hung) on the basis that there were 'traitors and rebels'. This point was important since it legitimised the actions of army officers acting under the command of the sovereign or his commander-in-chief. ${ }^{168}$ This rationale was preserved during the Civil War (1642-9) - both sides executing 'rebels' on the basis they had committed treason, a normal criminal offence as opposed to being a specific military one;

- Further, the Treason Act 1351 was expanded by the courts in the period 1517-1710 with a constructive interpretation of 'levying war' being made to cover great riots. ${ }^{169}$ The Act was also constructively expanded so that 'levying war' not only covered levying war against the sovereign (le roi) but also against the State. ${ }^{170}$

As a result, in all these cases, those who administered justice against rebels - whether common law judges, persons appointed by the Crown under commission or military officers - would probably have said:

'We are not administering military law as such - we are administering the law of the land, viz. the Treason Act 1351.'

Further, by the $17^{\text {th }}$ century, the degree to which martial law was imposed, diminished, since the normal courts soon interposed their jurisdiction. Thus, in the Monmouth rebellion in 1685 the notorious Jefferies CJ judged rebels according to the Treason Act 1351. ${ }^{171}$ After 1714, martial law - in any case - did not need to be relied on in England.

- The Riot Act 1714 applied to riots and it enabled rioters to be forcibly dispersed, an hour after the Act had been read: $:^{172}$

\footnotetext{
${ }^{164}$ Ibid, 45.Stephen, n 19, 210 (referring to the Petition of Right in particular) 'These authorities seem to show that it is illegal for the Crown to resort to martial law as a special mode of punishing rebellion.'

${ }^{165}$ Charles I sought to proclaim martial law affecting civilians in 1637 \& 1639, see $\mathrm{n} 146$.

166 Brand \& Nelson, n 37, 47.

${ }^{167}$ See ns 129-32. Cockburn CJ noted that people were put to death without trial after the Monmouth Rebellion in 1685 and the Jacobite Rebellions of $1715 \& 1745$. However, he asserted these people were slaughtered without any pretence of martial law. See also Tytler, $n 30$, 99-100. Holdsworth, n 55, vol 1, 577 'in 1685, after the suppression of Monmouth's rebellion, [Colonel Percy] Kirke [1649-91, in charge of the forces of James II against Monmouth] was directed to send soldiers guilty of serious crimes to the ordinary courts for trial, as the military code was only in force during the actual rebellion.' This would apply also to civilian rebels (albeit, in practice, it was not likely observed in various instances).

${ }^{168}$ Doubtless, this legitimized, in early times, the execution of persons on the sole command of the sovereign. The execution of persons such as the Earl of Lancaster in 1322 (when caught in open insurrection, see ns 108-11) would doubtless have been legitimized by Edward II (1307-27), who seems principally responsible for condemning the Earl, on the basis that the Earl had committed manifest treason (levying war, treated as treason prior to the Treason Act 1351). Further, Edward II would probably have asserted that the sovereign, as commander-in-chief, had the legal right to order the execution of rebels after battle on his own authority. It may be noted that his father, Edward I (1272-1307), had been a notable exponent of ordering the execution of rebels after battle, with scant or no trial. See Bellamy, n 53, n 44, ch 3, especially 40 (Scots rebellion of 1306).

${ }^{169}$ McBain, n 44, 102-7.

${ }^{170}$ Ibid, 107-15.

${ }^{171}$ For those killed out of hand, Cockburn CJ though this was no law at all and wholly illegal, see n 167.

${ }^{172}$ Under the Act, if 12 or more persons were riotously assembled to the disturbance of the public peace and they failed to disperse after being required to do so by a Justice of the Peace etc, this constituted a felony. Further, after having read the Riot Act and an hour having passed, if
} 
- There were no violent rebellions in England post- 1745 which required large scale military action; ${ }^{173}$

- In the case of violent demonstrations of people seeking political change on large scale (such as the Chartists who sought the reform of Parliament) the Treason Felony Act 1848 was enacted to deal with them. ${ }^{174}$

In conclusion - after 1627 - there were no major riots or rebellions in England which required the imposition of martial law against civilians (even if legal). ${ }^{175}$ However, martial law was imposed in Ireland and the colonies.

\subsection{Martial Law: Irish Riots and Rebellions: 1795-1833}

In Ireland, in 1795, rebellion against the Crown occurred and the civil authorities (it seemed) instituted martial law - exercising an asserted prerogative without proclaiming it as such. Because it was uncertain whether such a prerogative was legal or not, acts committed in suppressing the rebellion were sanctioned by an Irish Act of 25 March, 1799 and an indemnity was provided by an Irish Act of 1801 indemnifying acts from that date. ${ }^{176}$

- In 1798, there were more rebellions in Ireland, with insurrection breaking out in the counties of Kildare and Carlow. On 30 March 1798, Lord Camden (the lieutenant general) issued a proclamation declaring martial law. ${ }^{177}$ Many people were executed under it;

- A relevant case is that of Wolfe Tone (1798) ${ }^{178}$ although he was not executed, but committed suicide. Tone, an Irishman, was captured on board a French ship. Although Tone claimed to be a French officer and was dressed in the uniform of the same, he was sentenced to death for rebellion by a court martial in Ireland. An application was made to the court of King's Bench in Dublin for a habeus corpus on the ground he had been sentenced to death by an illegal court martial since the king's courts were still sitting and, thus, their ordinary jurisdiction had not been superceded (also that Tone, being a civilian, was not subject to a military court). A writ of habeus corpus was prepared, to prevent his execution. However, Tone committed suicide, dying some days before he could be brought before the court of king's bench.

His case gave rise to further concern about the legitimacy of the Crown to impose martial law when the courts were still open. As Cockburn notes,

after this it was thought desirable to supersede the proclamation of the lord - lieutenant appointing martial law, and to have statutory authority for its exercise, so as to preclude the intervention of martial law. ${ }^{179}$

This statutory authority was the Irish Rebellion Act 1803 (also called the Suppression of Rebellion Act 1803). ${ }^{180}$ Further, it seems clear that legal opinion at the beginning of the $19^{\text {th }}$ century was turning against the legitimacy of civilians being tried by military courts - even in the case of rebellion.

such riotous persons failed to disperse then they could be seized. If killed or maimed, the persons seizing them were indemnified. See also Dicey, n 16, 290.

${ }^{173}$ In the Jacobite rebellion of 1745, an Act empowered the sovereign (George II) to issue commissions for trying rebels in any county of the kingdom as if treason had been committed in that county. 19 Geo II c 9 (1746). See also McBain, n 44, 101 and Clode, n 19, vol 2, 163-8 (dealing with the $1715 \& 1745$ rebellions and the Gordon Riots of 1780. In the first two Acts of Indemnity were passed).

${ }^{174}$ McBain (2007a), 812-38.

${ }^{175}$ I exclude the purported application of martial law in limited circumstances, see ns 79-80 \& 146. See also Clode, n 19, vol 2, 666-7 (Circular Despatch of 30 January 1867 to Colonial Governors on the Subject of Martial Law). Finlason (1866), (i) n 19 'the Petition of Right abolished martial law in time of peace, and...happily, there has not been in this country, since the Revolution [of 1688] any state of rebellion that could be deemed to amount to war.'

17639 Geo III c 11 (An Act for the Suppression of Rebellion). Section 6 provided that 'nothing in this Act contained shall be construed to take away, abridge or diminish, the acknowledged prerogative of his majesty, for the public safety, to resort to the exercise of martial law against open enemies or traitors.' The Irish Indemnity Act of 1801 was 41 Geo III c 104. See also Anson, n 20, vol 2, pt 1, 316 and Brand \& Nelson, n 37, 50-1 \& 106. See also 36 Geo III c 6 (Irish Act, 1796 as amended) and 37 Geo III c 104 (Irish Act) (these did not refer to martial law as such). See generally Clode, n 19, vol 2, 168-74. See also Forsyth, n 5, 556.

${ }^{177}$ Forsyth, n 5, p 212 and Plowden (1806), vol 2, 690.Lord Camden was John Jeffreys Pratt, $1^{\text {st }}$ Marquess Camden (1759-1840), see ODNB, n 52. See also Stephen, $\mathrm{n}$ 19, 211. Finlason notes, n 19, 128 that, prior to the proclamation, 'The peasants had no arms but clumsy pikes and a few guns in bad order, they were of course easily defeated. All the prisoners taken by the soldiers were hanged without any trial, and there is reason to believe that many shared their fate who had not shared at all in the rebellion.....The cruelties committed by the militia in Wexford provoked an insurrection there, and horrible excesses were committed.' See also Finlason, n 19, 131 and Clode, n 19, vol 2, 169 \& 661-2 (proclamations). Also, Forsyth, n 5, 556

17827 ST 613 at 625. See also Brand \& Nelson, n 37, 51-3; Dicey, n 16, 293-4 and Forsyth, n 5, 557.

179 Brand, n 37, 53. 
- In 1798, in Ireland, one Grogan, a commissary general in the army of the rebel United Irishmen was seized by the forces of the Crown when they took Wexford. Tried by court martial, he argued he had committed no overt act but had been forced to take a nominal lead. Found guilty - along with two others he was executed on 28 June $1798^{181}$ and later attainted for treason by an (Irish) Act of 6 October, $1798 .^{182}$ Grogan was executed pursuant to a proclamation of martial law imposed in Wexford in April 1798 - but prior to any Irish Act sanctioning it, which happened in $1799 ;{ }^{183}$

- When it came to seeking a repeal of the Act of Attainder against him, the jurist Hargrave, when consulted professionally, indicated that, had he been consulted prior to the Act of Attainder, 'I should have deemed it fully open to me to express at least a doubt, - whether, under martial law, to try persons seized in rebellion, or seized upon suspicion of being rebels, before a court - martial constituted by the king's authority, and to punish them by death or otherwise, at the discretion of the members of such a court, was not an extension of martial law beyond its real object; and being so, was not an infringement of the law of England in a point of the most serious kind; ${ }^{184}$

- Hargrave made it clear that he thought such a purported Crown prerogative offended against the Petition of Right $1627 .{ }^{185}$ Thus, he was endorsing the opinion of Coke in 1641 that - if a rebel was executed in peacetime (ie. when the courts were still open) pursuant to military law (including pursuant to a trial before a court martial or other military court) - it was murder. ${ }^{186}$ The only exception was where Parliament expressly sanctioned the imposition of martial law. ${ }^{187}$

In 1833, when Ireland was again in a disturbed state, the Irish Coercion Act 1833 (also called the Insurrection Act 1833) was passed. It empowered the Lord Lieutenant to proclaim any county (or district) to be in a state or disturbance or insubordination. Also, for the same to order the convening of courts martial with a sergeant at law or barrister of not less than 5 years standing to act as judge advocate. ${ }^{188}$ As Cockburn CJ notes:

These instances of the application of martial law were therefore either under statutory powers, with which no man has, judicially speaking, a right to quarrel, or, when exercised by virtue of the prerogative of the crown, were followed by Acts of Indemnity; which, to say the least of it, sufficiently implies a doubt of the legality of the exercise of the power. ${ }^{189}$

\footnotetext{
18043 Geo III c 117 (1803)(rep)(An Act for the Suppression of Rebellion in Ireland). See also Brand \& Nelson, n 37, 34; Tytler, n 30, 407-8 and Clode, n 19, vol 2, 173-4. This Act, s 5, declared that 'nothing in this Act contained shall be construed to take away, abridge, or diminish the acknowledged prerogative of his majesty for the public safety, to resort to the exercise of martial law against open enemies or traitors.' See also Finlason, n 19, 132 and Robertson, n 85, 295.

${ }^{181}$ Cornelius Grogan (1738-98), see ODNB, n 52. Grogan was hanged and beheaded, his head placed on the court house and his body thrown in the river Slaney (it was later recovered and buried). See also Hay (1803) and Madden (1857-60).

${ }^{182}$ Also attainted were Lord Edward Fitzgerald (1763-98, a key militarist in the United Irishmen) and Beauchamp Harvey (1762-98, commander in chief of the United Irishmen). For both, see ODNB, n 52.

183 Opinion of Mr Hargrave in Irish Case Involving Martial Law, see Hargrave (1811), vol 1, 401 cited in Forsyth, n 5, 189. Hargrave stated 'that extremity [execution] was resorted to against him [Grogan], previously [ie. prior] to the Irish statute made in the $39^{\text {th }}$ of his present Majesty [ie. the Act of Indemnity, 39 Geo III c 11, see n 176], for suppression of the rebellion in Ireland.' In Ireland, various Acts saved the right of the Crown 'for the public safety to resort to the exercise of martial law against open enemies and traitors'. See 27 Geo 3 c 15 (1787) (Irish), Suppression of Rebellion in Ireland Act 1803 (rep), Suppression of Disturbances and Associations in Ireland Act 1833 (also called the Irish Coercion Act), s 40 (rep). See also Halsbury, n 13, vol 8(2), para 821, n 12.

${ }^{184}$ Forsyth, n 5, 190. See also Tytler, n 30, 367 (writing in 1806). Only in the case of absolute necessity did Tytler think that the Crown could impose martial law, see 46. In this Tytler is referring to the Crown Prerogative in the case of emergencies, as discussed in 7.

${ }^{185}$ Ibid, 192. See also Rushworth, n 25, vol 3, App.

${ }^{186}$ See 104. So too in the case of an alien who was not an enemy alien. See Forsyth, n 5, 201.

${ }^{187}$ Comyns, n 15 (title Parliament), 300, 'Martial law cannot be used in England without authority of Parliament.'

1883 \& 4 Will IV c 4 (1833)(rep)(An Act for the more effectual suppression of local disturbances and dangerous associations in Ireland). This Act, $\mathrm{s} 40$, enacts that 'nothing in the Act contained shall be construed to take away, abridge, or diminish the... undoubted prerogative of his majesty, for the public safety, to resort to the exercise of martial law against open enemies or traitors.' See also Brand \& Nelson, n 37, 55; Forsyth, n 5, 212; Stephen, n 19, 211; Finlason, n 19, 5 and Clode, n 19, vol 2, 174-5.

189 Brand \& Nelson, n 37, 57. Stephen, n 19, 211 (commenting on the Irish Coercion Act 1833) indicates that it cannot be supposed to repeal the Petition of Right 1627. Therefore, 'the words in the Irish Act would mean only that the Crown has an undoubted prerogative to carry on war against an army of rebels as it would against an invading army, and to exercise all such powers as might be necessary to suppress the rebellion and to restore the peace and to permit the common law to take effect.'
} 
After 1838, the need for imposing martial law in Ireland was obviated by the Treason Felony Act 1848. This was sufficient until large scale rebellion broke out prior to the independence of Southern Ireland in $1922 .{ }^{190}$ It may be noted that, in the troubles in Northern Ireland which occurred since 1969, martial law was never invoked. ${ }^{191}$

In conclusion, in the period 1798 - 1838, the imposition of martial law in Ireland was supplemented by legislation, due to doubts as to the legality of the exercise by the Crown of its prerogative.

\subsection{Riots and Rebellions in the Colonies}

Martial law was also imposed by the Crown in various colonies, in order to deal with rebellions. ${ }^{192}$ Reference may be made rebellions in:

- Demerara (British Guyana) in 1823. A rebellion of Negro slaves broke out in 1823 and martial law was proclaimed between 18 August 1823 - 15 January $1824 ;{ }^{193}$

- Canada in 1837 - 8. In 1837 - 8, Quebec rebels opposed the British colonial government. Martial law was declared by Governor Gosford between 5 December1837 - 27 April 1838;

- South Africa in 1835 - 6, in 1846 - 7 and in 1850 - 3;

- Ceylon in 1848. Martial law was declared by Governor Torrington between 29 July and 10 October 1848 to deal with a Kandyan revolt (the 'Matale' rebellion'); ${ }^{194}$

- Jamaica in 1831 - 2 and in 1865 (see 4.1 above). Martial law was proclaimed on $13^{\text {th }}$ October 1865 for four weeks, under the regime of Governor Eyre; ${ }^{195}$

- Cape of Good Hope and Natal in 1901 and 1906 - 8. Martial law was proclaimed in certain districts, in August 1901. It was later extended to the conquered Boer republics in the South African war of 1899 1902. Martial law was also resorted to in Natal in 1906 - 8 and, later, in the Union of South Africa;

- Ireland in 1798, 1916 and 1920. For martial law in 1798 (see 4.1 above). There was also rebellions against the British Government in 1916 (Easter Rising) and in 1920 - 1. After the Anglo - Irish treaty of

\footnotetext{
${ }^{190}$ See McBain, n 174. The problem the British authorities were faced with in Ireland after 1798 was large scale civil unrest - usually designed to remove colonial rule from Ireland. In the case of large scale violence directed to achieving these ends the British government found that invoking the Treason Act 1351 with it especially draconian punishment did not work, since juries would not convict. Nor did the law of sedition, since it did not have enough 'bite'(see McBain, 819, n 66 (sedition was a bailable offence and there was no right of forfeiture, for treason felony there was). Thus, in 1848, the Treason Felony Act was passed to 'catch' largescale acts of violence directed to changing the law or the status of the sovereign. It imposed a lesser penalty than treason (usually transportation). As it was, after 1848, in Ireland most violence against British rule transmuted into smaller acts of sabotage - including the use of explosives. This resulted in the Explosives Act 1885, being enacted. After 1887, violent resistance petered out until the 1st World War (1914-8).

${ }^{191}$ Bradley \& Ewing, n 16, 632 'In Northern Ireland since 1969, at no time has the British government invoked the doctrine of martial law as a justification for exempting the actions of the forces from scrutiny in the courts; instead there has been reliance on statutory powers or on the use of common law powers falling far short of a martial law situation.' For legislation enacted to deal with the Troubles, see Phillips \& Jackson, $\mathrm{n}$ 16, 402-3. See also the Indemnity Act 1920, ibid, 403.

192 See Clode, n 19, vol 2, 481-511.

${ }^{193}$ See Bryant (1824), Da Costa (1994) and Clode, n 19, vol 2, 482-90. For rebellions in Barbados in 1805 \& 1816, Ibid, 481-2.

${ }^{194}$ Mills (1964), ch 10.ACommittee of Enquiry appointed by the House of Commons presented a Report to Parliament in March 1850 (for citations as to the proceedings and evidence, see Mills, 189, $\mathrm{n}$ 3). See also Stephen, $\mathrm{n}$ 19, vol 1, 213. For allegations as to the inadequacy of the military courts in the rebellion, see Mills, 194-6 (18 rebels were shot, 66 imprisoned and 28 transported). Lord Torrington was George Byng, $7^{\text {th }}$ Viscount Torrington (1812-4), Governor of Ceylon (1847-50), see ODNB, n 52. See also Wikipedia on the Matale rebellion. For an earlier rebellion in Ceylon in 1817-8 against the British, see Mills, 161-3. See also Clode, $n$ 19, vol 2, 501-2. For rebellion on the island of Cephalonia in 1849, see 502-3; in the Cape of Good Hope in 1835, 1846 \& 1850, see 503- 9 and on the island of St Vincent in 1862, see 503-11. It may be noted that, by the time of the latter, persons arrested during martial law were tried by civil tribunals (127 were convicted of felony).

${ }^{195}$ Brand \& Nelson, n 37, 6. See Clode, n 19, vol 2, 490-7 (for the terms of the proclamation, p 492). This rebellion is particularly problematic since the governor Eyre extended martial law for 30 days when the rebellion had been put down in a couple of days (11-13 October 1865) and it was practical thereafter to try persons in the ordinary courts. Further, while the immediate rebellion killed 20 people, the aftermath resulted in (it is thought) in 439 black Jamaicans being killed by soldiers, 354 later executed (many under martial law) and 600 men and women flogged. Today, the response would be treated as disproportionate to the response. See $R v$ Eyre (1867), n 127, p 74. Also, Heuman (1994). Also Wikipedia (Morant Bay rebellion).
} 
1921, the Provisional Government of the Irish Free State (in office for ten months) resorted to martial law against the opponents of the treaty. ${ }^{196}$

In respect of a rebellion in Canada in $1837-8,{ }^{197}$ reliance was not placed on the right of the Crown prerogative to impose martial law but on an Act of Parliament which authorised the imposition of martial law. This point was made in a Joint Opinion delivered in 1838 by the Attorney General (Sir John Campbell) and the Solicitor General (Sir RM Rolfe) as to the power of the Governor of Canada to proclaim martial law. ${ }^{198}$ Noting that - whether a proclamation of martial law was made or not - was irrelevant to the state of affairs, ${ }^{199}$ the law officers stated:

In any district in which, by reason of armed bodies of the inhabitants being engaged in insurrection, the ordinary course of law cannot be maintained, we are of opinion that the Governor may, even without any proclamation, proceed to put down the rebellion by force of arms, as in the case of foreign invasion, and for that purpose may lawfully put to death all persons engaged in the work of resistance; and this, as we conceive, is all that is meant by the language of the statutes referred to in the report of the Attorney and Solicitor General for Lower Canada, when they allude to the "undoubted prerogative of his Majesty for the public safety to resort to the exercise of martial law against open enemies and traitors. ${ }^{200}$

They continued by emphasizing that the power of the Crown to so act could now only be conferred by Parliament.

The right of resorting to such extremity is a right arising from and limited to the necessity of the case quod necessitas cogit, defendit.

For this reason we are of the opinion that the prerogative does not extend beyond the case of persons taken in open resistance, and with whom, by reason of the suspension of the ordinary tribunals, it is impossible to deal according to the regular court of justice. ${ }^{201}$

When the regular courts are open, so that criminals might be delivered over to them to be dealt with according to law, there is not, as we conceive, any right in the Crown to adopt any other course of proceeding. Such power can only be conferred by the legislature, as was done by the Acts passed in consequence of the Irish rebellions of 1798 and 1803, and also the Irish Coercion Act of $1833 .{ }^{202}$ (wording divided for ease of reference)

In conclusion, by 1838, England's law officers (opining on behalf of the Crown) had restricted the application of martial law to rebellions where (i) persons were taken in 'open resistance' and (ii) the courts were not open to enable rebels to be dealt with 'according to the regular court of justice.' This situation was treated as akin to war (see 7).

\footnotetext{
${ }^{196}$ Anson, n 20, vol 2, pt 1, 316. In the Easter Rising of 1916, martial law was declared by Lord Wimborne, lord lieutenant on 24 April 1916. The rising lasted from 24-30 April 1916. Apart from those killed in fighting, six civilians were summarily executed on the orders of an army officer at Portobello barracks, Dublin. Fifteen persons were also executed by firing squad after court martial which began to 2 May 1916. For Ivor Churchill Guest, $1^{\text {st }}$ Viscount Wimborne (1873-1939) see ODNB, n 52.

197 See generally Schull (1971), Greenwood \& Wright ( 2002), Forsyth, n 5, 198-206, Clode, n 19, vol 2, $497-500$ and 39 Parliamentary Papers (1837-8).

${ }^{198}$ Forsyth, n 5, $198-206$.

199 Ibid, 198 'such proclamation confers no power on the Governor which he would not have possessed without it. The object of it can only be to give notice to the inhabitants of the course which the Government is obliged to adopt for the purpose of restoring tranquility.'

In a Legal Opinion of the Attorney General (Sir Robert Henley) and the Solicitor General (Hon Charles Yorke) in respect of an anticipated invasion of Jamaica (a settled colony) in 1757, they indicated that a proclamation of martial law did not stop the execution of legislative authority by the civil authorities. "Nor do we apprehend that by such proclamation of martial law, the ordinary course of law and justice is suspended or stopped, any further than is absolutely necessary to answer the then military service of the public and the exigencies of the province.' See Forsyth, n 5, 188-9 and Anson, n 20, vol 2, pt 1, 318 'It is clear also that the declaration of martial law makes no real difference to the situation, save that it serves to warn the people of the locality where martial law is proclaimed of the intentions of the government.' See also Bradley \& Ewing, n 16, 633.

200 Ibid.

201 The Legal Opinion continues, 199, 'the question, how far martial law, when in force, supercedes the ordinary tribunals, can never, in our view of the case, arise. Martial law is stated by Lord Hale to be in truth no law [see n 100], but something rather indulged than allowed as a law, and it can only be tolerated because, by reason of open rebellion, the enforcing of any other law has become impossible. It cannot be said in strictness to supercede the ordinary tribunals, inasmuch as it only exists by reason of those tribunals having already been practically superseded. It is hardly necessary for us to add that, in our view of the case, martial law can never be enforced for the ordinary purposes of civil or even criminal justice, except, in the latter, so far as the necessity arising from actual resistance compels its adoption.'

${ }^{202}$ Forsyth, n 5, 198-9. See also Bradley \& Ewing, n 16, 633.
} 


\subsection{Riots and Rebellions - Position Today}

By 1838 , at the latest, legal opinion accepted that any Crown prerogative to impose martial law on civilians - even in the case of riots or rebellions (cf. where war prevailed) - was contrary to the Petition of Right $1627 .{ }^{203}$ In more modern times Dicey (in 1948) stated:

Soldiers may suppress a riot...but they have no right under the law to inflict punishment for riot or rebellion... ${ }^{204}$

More explicitly, Holdsworth (writing in 1938) stated:

Though the military jurisdiction of the court [ie. the court of the constable and marshal] has ceased to exist, the limitations placed upon it by the Petition of Right, and the subsequent development of courts martial exercising jurisdiction over the soldiers of the crown, have had a very permanent constitutional result. Their joint effect has been to vest jurisdiction over civilians in times of riot and rebellion in the ordinary courts of common law, and not in military courts.

Civilians are even then governed by the rules and processes of the common law, and not by the rules and processes applicable to the soldier...[the] victory over the constable and marshal's court has left the case of riot or rebellion to the common law, and has caused the 'state of siege' to be practically unknown in England. ${ }^{205}$ (italics supplied and wording divided for ease of reference)

This statement, which reflects that of Coke in 1641, applies a fortiori, today, for a number of reasons.

- Unlike previous centuries, there is now a permanent, and well-equipped, police force to deal with riots. There is also distinct legislation on the offence of rioting as well as related offences; $;{ }^{206}$

- Where the police needed re-enforcements post - 1848, usually special constables were used and not the army; ${ }^{207}$

- Levying war against the sovereign is still treason under the Treason Act 1351; and there is no reason why the courts cannot handle the (highly unlikely) case today of people rebelling, in an attempt to overthrow Elizabeth II $;^{208}$

- The Treason Felony Act 1848 still exists to deal with large crowds who seek to use violence to require Parliament to change laws or to change to the monarchy;

- If the army is required to assist the police in the realm, they (like any other citizen) may use such force (including shooting) as is reasonable in the circumstances, ${ }^{209}$

- The Crown has a separate prerogative to act in the case of emergencies (see 6), such that there is no need in modern times to subject civilians to martial law and to military courts;

- The Civil Contingencies Act 2004 (see 7) empowers the Crown to act in the case of emergencies and to make regulations. These may subject civilians (including rioters and rebels) to special civil courts for criminal offences. Thus, subjecting civilians to military courts is not necessary.

Thus, there is no reason whatsoever to subject civilians to martial law in the case of riots and rebellions today. In any case, imposing martial law would be a brutum fulmen in modern times since the whole purpose of subjecting civilians to martial law in past centuries was to impose the death penalty - or harsher military penalties(whipping etc) - than were otherwise possible pursuant to the common law. However, in England, the death penalty has been abolished since 1998 for all offences. Harsh military penalties have also long been abolished.

\footnotetext{
203 Also, martial law was treated as being limited (as per Coke) to acts committed in the heat of battle, and not afterwards.

204 Dicey, n 16, 293.

${ }^{205}$ Holdsworth, $\mathrm{n} 55$, vol 1, 578. It is to be remembered that Hale held that martial law was only allowed 'in cases of necessity, in time of open war.' See n 107.

206 Public Order Act 1986, s 1 (6). There is also separate legislation dealing with firearms, knives, appearing in military dress etc.

207 Stephen, n 19, vol 1, 206 (writing in 1883), 'Happily the employment of military force for the suppression of a riot is a matter of rare occurrence in this county. When there is reason to fear any tumult with which the common police establishment cannot deal, the course usually taken is to swear in special constables... On one memorable occasion, however (April 10, 1848), the swearing in of a vast number of special constables in London and elsewhere, as an answer to threats of revolutionary disturbance, was of much use, as a proof of demonstration of the fact that the great bulk of the population were at the time opposed to any resort to violence for political objects.'

208 The attempt would be worthless anyway since...the Bill of Rights 1688 establishes that Parliament can determine who is sovereign. Further, the mere taking of the sovereign into captivity, or declaring her to be deposed etc, would not change her status.

${ }^{209}$ See n 250.
} 
In conclusion, the general principle of Coke that civilians cannot be subject to martial law in peacetime still prevails (the same to include riots and rebellions not amounting to open war). This leaves, however, some Irish cases in the 1920's, when opposition to colonial rule led to the formation of the Irish republic. In these - at first the Crown prerogative to impose martial law was asserted. However, it was soon re-enforced by legislation. These are now considered.

\section{Martial Law - Military Law Imposed on Civilians in War Time}

Today, any assertion by the Crown of a prerogative to impose martial law on civilians in time of peace (including riots and rebellion) is illegal. However, does the Crown retain such a prerogative in time of war? That is, in the case of foreign invasion or civil war? Statements in Halsbury on this are confused because they conflate war with riots and rebellion. They also confuse martial law with quite separate Crown prerogatives to:

- act in the case of emergency;

- $\quad$ keep the peace.

Halsbury states:

The Crown may not issue commissions in time of peace to try civilians by martial law; but when there exists a state of actual war, or of insurrection, riot or rebellion amounting to war, the Crown and its officers may use the amount of force necessary in the circumstances to restore order. ${ }^{210}$ This use of force is sometimes termed 'martial law'. ${ }^{211}$ (italics supplied)

This statement is confused in that 'insurrection, riot or rebellion' only 'amount' to war in the case of civil war. Thus, only civil war should be referred to. It is the lack of such definition - and the uncertain meanings of 'insurrection' and 'rebellion' in a general context (as well as the fact that they are not legal terms) ${ }^{212}$ - which is the source of one of the problems in respect of martial law, and any legal analysis of it. Halsbury also states:

Once a state of actual war exists the civil courts have no authority to call in question the actions of the military authorities, but it is for the civil courts to decide, if their jurisdiction is invoked, whether a state of war exists which justifies the application of martial law. ${ }^{213}$ The powers, such as they are, of the military authorities cease and those of the civil courts are resumed ipso facto with the termination of the state of war, ${ }^{214}$ and, in the absence of an Act of Indemnity, ${ }^{215}$ the civil courts may inquire into the legality of anything done during the state of war. ${ }^{216}$

\footnotetext{
${ }^{210} R v$ Hampden (1637) 3 ST 826 at 976 (Holbourne's argument) 'the general law of necessity, which is above all laws, for the public good private good doth yield on all parts.' At 1162, per Croke J, 'Royal power, I account, is to be used in cases of necessity, and imminent danger, when ordinary courses will not avail... as in cases of rebellion, sudden invasion, and some other causes, where martial law may be used, and may not stay for legal proceedings. But in time of peace, and no extreme necessity, legal courses must be used and not royal power.' See also Brand \& Nelson, n 37, 85; Forsyth, n 5, 198-9 and Clode, n 19, vol 1, 5.

${ }^{211}$ Halsbury, n 13, vol 8(2), para 821. See also Forsyth, n 5, 198-9, 556-7.

${ }^{212} \mathrm{OED}, \mathrm{n} 20$ (insurrection) 'The action of rising in arms or open resistance against established authority or governmental restraint; with pl., an instance of this, an armed rising, a revolt; an incipient or limited rebellion.' (rebellion) '1 Organised armed resistance to the ruler or government of one's country; insurrection, revolt. 2. Open or determined defiance of, or resistance to, any authority or controlling power.'

${ }^{213} R$ (O'Brien) v Military Government of North Dublin Union Military Internment Camp [1924] 1 IR 32 at 38, 'The court is bound, when its jurisdiction is invoked, to decide whether or not there exists a state of war or armed rebellion; but once it so decides, it has no power to prohibit, control, or interfere with any act of the military forces, whether it is a matter of detention, as in the present case, or the execution of a capital sentence after trial by a so-called military court...or the execution of a person without trial...' $R$ (Garde) $v$ Strickland [1921] 2 IR 317, per Molony CJ at 329 'this court has the power and the duty to decide whether a state of war exists which justifies the application of martial law'. $R$ (Childers) $v$ Adjutant General of the Provisional Forces [1923] 1 IR 5 (the applicant was arrested and charged with possessing a pistol. On an application for habeus corpus, it was held the writ must be refused, as a state of war being proved, the military to whom the duty of repelling force by force was committed, were the sole judges of how it should be exercised). See also Heuston, n 16, 157- 62.

${ }^{214}$ Wolfe Tone's Case (1798) 27 ST 613 at 625 (counsel to Tone) 'no court martial could have cognizance of any crime imputed to him, while the court of king's bench sat in the capacity of the great criminal court of the land. In times when war was raging, when man was opposed to man in the field, courts martial might be endured; but every law authority is with me, while I stand upon this sacred and immutable principle of the constitution - that martial law and civil law are incompatible; and that the former must cease with the existence of the latter.' See also Stephen, n 19, 212.

${ }^{215}$ Halsbury, n 13, vol 8(2), para 821, n 12, notes that Acts of Indemnity may be passed, in part, to obviate the uncertainty as to the Crown's prerogative to declare martial law. Heuston, n 16, 162-3 quotes Dicey (2007), 55 'of all the laws which a legislature can pass an Act of Indemnity is the most likely to produce injustice. It is on the face of it the legislation of illegality; the hope of it encourages violations of law and
} 
It is asserted the modern position can be better determined by having separate regard to foreign invasion and internal insurrection. It may be remembered that the Petition of Right 1627 is not clear on the legality of the Crown to declare martial law in the case of war time. ${ }^{217}$

\subsection{Foreign Invasion}

Halsbury notes there are no English examples. As it is, England has not been invaded by a foreign power since William I (1066-87). Further, during World War I (1914-18) and II (1939-45), the Crown did not declare martial law. ${ }^{218}$ In particular, it did not seek to submit civilians to courts martial. ${ }^{219}$

- If there were any prospect (or actuality) of an invasion today, there is no reason why the Crown should need to declare martial law in any case. And, if it were required, emergency legislation could be enacted to so provide (see 7);

- Further, the Crown has a general prerogative to act in an emergency (see 6). This could include the establishment of war zone (or summary) courts to administer criminal justice to civilians. Thus, any Crown prerogative to submit civilians to martial law is unnecessary even in the event of foreign invasion - whether actual or anticipated;

- Finally, even if an invasion was so sudden that Parliament was unable to assemble to pass legislation, the Crown has authority to take emergency action act under the Civil Contingencies Act 2004 (see 7). This would include the establishment of courts to deal with criminal acts by civilians. Thus, there is no need to impose martial law (and military courts of whatever nature) on civilians in the event of invasion. ${ }^{220}$

\subsection{Internal Insurrection}

Riots and rebellions have already been considered in 4 . There are, however, instances which Halsbury cites as akin to war. It refers to a notice issued in:

- South Africa in 1902 during the Boer war when it was part of the British Empire; ${ }^{221}$

- Ireland in 1920 when it was part of the British Empire. ${ }^{222}$

There are some important points to note in respect of these precedents:

- These precedents are now nearly (or more than) 100 years old and they will not occur again since South Africa and Southern Ireland are no longer part of the British Empire. Today, the Crown could only apply,

of humanity. The tale of flogging Fitzgerald in Ireland, or the history of governor Eyre in Jamaica [see n 127], is sufficient to remind us of the deeds of lawlessness and cruelty which in a period of civil conflict may be inspired by recklessness or passion, and may be pardoned by the retrospective sympathy or partnership of a terror-stricken or vindictive legislature.'

${ }^{216}$ Higgins $v$ Willis [1921] 2 IR 386 (so long as a state of war exists, an action for damages for wrongful destruction of property by military forces in a martial law area cannot be tried; but the plaintiff has a right to have his case proceeded with so soon as a state of war no longer prevails). See also Halsbury, n 13, vol 8(2), para 821.

${ }^{217}$ See $n 154$

${ }^{218}$ Halsbury, n 13, vol 8(2), para 821'No state of martial law was declared in the United Kingdom during the two world wars.' Ibid, n 1. Halsbury also notes that, prior to World War II, the Emergency Powers (Defence) Act 1939 (rep) was passed. The making of provision for trial by courts martial of non- military persons was expressly excepted from the power to make defence regulations. Ibid, s 1(5). See also Halsbury, n 13, vol 8(2), para 821, n 1 .

${ }^{219}$ The Emergency Powers (Defence) (No 2) Act 1940 gave authority for special war zone courts to exercise criminal jurisdiction if, on account of military action, criminal justice had to be more speedily administered than in the ordinary courts. See also Bradley \& Ewing, n 16,632-5 and Halsbury, n 13, vol 8(2), para 821, n 16 and para 820, n 4 .

${ }^{220}$ The only point of doing so today, would be to submit civilians to military courts. However, war zone courts presided over by civil judges would be more appropriate. See $\mathrm{n} 219$.

${ }^{221}$ Exp Marais [1902] AC 109. For an older instance of imposing martial law in war time see Forsyth, n 5, 211 (Pursuant to Regulation 10 of 1804, the Governor General of India in Council was empowered to establish martial law in time of war, or during open rebellion, in any part of British territory subject to the government of the presidency of Fort William). See also Finlason, n 19, 6.

${ }^{222} R$ v Allen [1921] 2 IR 241 at 261 (Proclamation of 10 December 1920. The lord lieutenant proclaimed certain Irish cities to be under martial law and he called on all loyal and well affected subjects of the Crown to obey and conform to all orders and regulations of the military authority issued by virtue thereof). See also Heuston, n 16, 154-7. For a useful chapter on the caselaw, see Ewing \& Gearty (2000) ch 7. 
in any case, martial law - besides in the realm - to the British Overseas Territories (formerly called Crown colonies or British Dependent Territories). These are few and far between; ${ }^{223}$

- In the $19^{\text {th }}$ century, the courts were forced to re-look at Coke's definition of war and peace for the purposes of martial law - as to whether the courts were open or shut. ${ }^{224}$ This was due to modern warfare giving rise to the situation that the courts might be technically open - but unable to operate due to security concerns or there being unable to cope (in some way) with handling criminal offences committed by civilians of a military nature, ${ }^{225}$

- In Elphinstone v Bedreechund (1830) ${ }^{226}$ and - more particularly - Ex p Marais (1902), it was held that martial law could still be declared even if the courts were not physically shut, provided war was 'raging'. ${ }^{227}$ The effect of this, however, was problematic since there was then no hard and fast line between when civilians could be tried by military courts and when not - something of great import when the life of a man was at stake and when military justice could be summary and haphazard;

- The effect of martial law being held to exist was that the normal courts could not question the acts of military courts - however improper. ${ }^{228}$ Thus, citizens could be put to death without a trial - or pursuant to a perfunctory trial (or a biased one);

- In the case of Ireland in the 1920's, special legislation accorded the military powers the right to put down the rebellion. Unlike the Crown prerogative - in the case of this legislation - the courts held they were able to compel the military authorities to act in accordance with its terms, see Egan v Macready (1921); ${ }^{229}$

\footnotetext{
${ }^{223}$ Anguilla, Bermuda, British Antartic Territory, British Indian Ocean Territory, British Virgin Islands, Cayman Islands, Falkland Islands, Gibraltar, Montserrat, Pitcairn Islands, St Helena, Ascension and Tristan da Cunha, South Georgia and the South Sandwich Islands, Sovereign Base Areas of Akrotiri and Dhekelia, Turks and Caicos Islands. Many of these have tiny populations (see in brackets) and thus the idea of extending war to them would be of little worth.

${ }^{224}$ See n 155.

${ }^{225}$ As Holdsworth puts it, $\mathrm{n} 55$, vol 1, 576, n 3, the issue is whether the courts are sitting in their own right or as licencees of the military. Halsbury states, n 13, vol 8(2), para $821, \mathrm{n} 7$ 'Of course, the fact that the courts need military protection in order to function is evidence of a state of war: see Childers, n 213 per O'Connor MR at 15 'Can the [Supreme] Court be said to be freely functioning when it requires the protection of a military guard, when the circuits of the judges are interfered with, and when some of the county court judges dare not enter their districts ? ....The truth is that the courts are just struggling for continued existence in the state of war which is now prevailing. They are not functioning as in times of peace.' See also Phillips \& Jackson, n 16, 399.

${ }^{226} 1$ Knapp's Privy Council Appeal Cases (1829-31), vol 1,316. Members of the provisional government of a recently conquered country (a territory in India) seized the property of a native of that country. It was held this seizure was in the nature of a hostile seizure and the municipal government had no jurisdiction. Lord Tenterden, 316. 'We think the proper character of the transaction was that of a hostile seizure made, if not flagrante, yet nondum cessante bello... and consequently, that the municipal court had no jurisdiction to adjudge upon the subject.' See also (1830) 2 STNS 379 and Holdsworth, n 19, 129-30.

${ }^{227}$ Ex p Marais (n 221), per Lord Halsbury, pp 114-5 'They [their Lordships] are of opinion that where actual war is raging acts done by the military authorities are not justiciable by the ordinary tribunals...The fact that for some purposes some tribunals had been permitted to pursue their ordinary course is not conclusive that war was not raging... The truth is that no doubt has ever existed that where war actually prevails the ordinary courts have no jurisdiction over the action of military authorities.' This case was one of appeal from the Supreme Court of the Cape of Good Hope. Martial law had been proclaimed and the appellant had been arrested for contravening Martial Law Regulations of 1 May 1901, part 14 s 2 (dealing with the enemy). See also Bradley \& Ewing, n 16, 633.

${ }^{228}$ A-G for Good Hope v Van Reenen [1904] AC 114 (the Supreme Court of Good Hope had no jurisdiction to review judgments of martial law courts); $R$ v Allen (n 222); $R$ (Garde) v Strickland (n 213)(found guilty before a military court of levying war) per Molony CJ at $\mathrm{p} 332$ 'once the state of war justifying martial law is established to our satisfaction, we cannot interfere to determine what is or what is not necessary.' $R$ (Ronayne and Mulchay) $v$ Strickland [1921] 2 IR 333 (when a state of facts exists which justifies the imposition of martial law, the forces of the Crown, without any proclamation, may be employed in executing it). Higgins $v$ Willis (n 216). R (Childers) (n 213) (arrested and charged with possessing a pistol. On an application for habeus corpus, held that the writ must be refused, since a state of war being proved, the military to whom the duty of repelling force by force was committed, were the sole judges of how it should be exercised, per O'Connor MR at 14-5 'once a state of war arises the civil courts have no jurisdiction over the acts of the military authority during the maintenance of hostilities.' See also Johnstone v O'Sullivan [1923] 2 IR 13 per Pim J (there is an inherent right at common law in every government that may be attacked to defend itself, and to form an army for the protection of itself and the people committed to its charge).

${ }^{229}$ [1921] 1 IR 265 (O'Connor MR held that the exercise of martial law was part of the royal prerogative and, as such, regulated by the Restoration of Order in Ireland Act 1920 (rep) with the result that civil courts retained jurisdiction to compel military authorities to act in accordance with the Act, disagreeing with $R v$ Allen (n 222). See also Bradley \& Ewing, n 16, 634.
} 
- As Anson notes, in all of these colonial cases, the general policy of the Crown was to pass Indemnity Acts ex post facto. As a result, this deprived the courts of the opportunity to declare more fully the principles of martial law. Thus, it left many legal issues largely unresolved. ${ }^{230}$

In Ireland, the Restoration of Order in Ireland Act 1920 (passed by the Westminster Parliament) empowered the use of the Crown prerogative to declare martial law. ${ }^{231}$ Anson notes:

In the difficulties of 1920 - 1 the Restoration of Order in Ireland Act, 1920, was held ${ }^{232}$ to authorise very drastic measures, but also to restrict the operations of the military to those provided under the Act, as constituting a statutory regulation of the prerogative. But in other $\operatorname{cases}^{233}$ a much wider view was taken, perhaps more correctly. In the later struggle it was held that there were no statutory limitations. ${ }^{234}$

Today, there is little doubt that - if situations such as in the Boer War or Irish rebellions were to re-occur legislation would be used to impose any martial law over citizens because of all the uncertainly as to the legality of the Crown prerogative. Be that as it may, in the case where the courts have no power to question military jurisdiction over civilians - including their being judged by military courts - it is debatable whether this can be said to be 'martial law' at all.

\subsubsection{Martial Law is no Law, Military Courts are no Courts}

Cockburn CJ in $R v$ Nelson \& Brand (1867) - following Hale and Blackstone - did not think martial 'law' could be termed as such. It was a state of no law at all ${ }^{235}$ - the application of military force in a legal vacuum - albeit the normal courts might determine the legality of such actions once peace was restored. ${ }^{236}$ Endorsing this, Halsbury LC stated in Tilonko $v$ AG of Natal (1907) that:

It is by this time a very familiar observation that what is called 'martial law' is no law at all. The notion that 'martial law' exists by reason of the proclamation... is an entire delusion. The right to administer force against force in actual war does not depend upon the proclamation of martial law at all. It depends upon whether there is a war or not. ${ }^{237}$

If martial law is no law - as a corollary - military courts do not comprise 'courts'. Halsbury LC also stated:

It is clear that so called military courts set up under martial law are not really courts at all. ${ }^{238}$

\footnotetext{
${ }^{230}$ Anson, $\mathrm{n} 20$, vol 2, pt 1, 317.

${ }^{231}$ See generally Bradley \& Ewing, n 16, 634. Also, Campbell (1994) and Jones (1969), vol 3, pt 1.

${ }^{232}$ Egan v Macready (n 229).

${ }^{233} R v$ Allen (n 222). In December 1920 - although the Restoration of Order in Ireland Act 1920 was in force (providing for civilians to be tried by properly convened courts martial and prescribing the maximum penalties) - martial law was proclaimed in areas in Ireland, (including that in which Allen was) and the general officer commanding the army declared that any unauthorized person found in possession of arms would be subject to the death penalty. The general also established informal military courts for administering summary justice to those alleged to have committed the prohibited acts. The King's Bench division in Ireland refused to intervene in the case of a death sentence imposed by such a military court on Allen for possession of arms. It was immaterial, the court held that Parliament had not imposed the death penalty for such an offence. See also Bradley \& Ewing, n 16, 634.

${ }^{234} R$ (Childers) (n 213).

${ }^{235}$ See Brand \& Nelson, n 37, 86. Halsbury, n 13, vol 8(2), para 821 'Probably the correct view to take of martial law itself is that it is no law at all.' See also the observation of the Duke of Wellington in the House of Lords on 1 April 1851 (on the question of the Ceylon rebellion in 1849, see n 194) 'Martial law is neither more nor less than the will of the general who commands the army; in fact, martial law is no law at all.' See also Forsyth, n 5, 211 who quotes Earl Grey on the same occasion 'what is called martial law is no law at all, but merely for the sake of public safety in circumstances of real emergency, setting aside all law, and acting under the military power.' Anson, n 20, vol 2, pt 1, 315 '[Martial law] is also used for the rules enforced in enemy territory under British occupation, the sense in which it is defined by the Duke of Wellington as being no law.' See also Finlason, n 19, 9-10, 140; Halsbury, n 13, vol 8(2), para 821, n 16 and Holdsworth, n 16, 128. See also Clode, $\mathrm{n}$ 67, 184-5 and Forsyth, n 5, 558 (Sir Robert Peel, martial law is a rule of necessity).

${ }^{236} R$ (Ronayne and Mulchay) $v$ Strickland (n 228) per Molony CJ at 334 'We hold that when a state of things does exist which justifies the 'execution of martial law', and such is proved to our satisfaction, our hands are tied... When the state of war is over, the acts of the military during the war, unless protected by an Act of Indemnity, can be challenged before a jury; and in that event even if the king's command would not be an answer if the jury were satisfied that the acts complained of were not justified by the circumstances then existing and the necessities of the case.'

${ }^{237}$ [1907] AC 93 at 94.

${ }^{238}$ Ibid, per Halsbury LC at p 95 'Such acts of justice are justified by necessity, by the fact of actual war.' Stephen (writing in 1883), n 19, vol

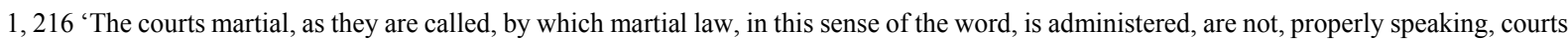




\subsubsection{Effect of No Law and No Courts}

The effect of martial law being no law - and military courts being no courts - produces an unsatisfactory situation where the lives of civilians can be forfeit pursuant to the decisions of extra-legal courts which are wholly unaccountable to anyone at the time - and from which there is no system of appeal. Thus, in Clifford v O'Sullivan (1921), a proclamation had been issued by the Lord Lieutenant in Ireland on 10 December 1920 that certain counties (including county Cork) were under martial law. This was followed by another proclamation two days later in which the commander-in-chief in Ireland declared the unauthorised carrying of arms to be punishable by death. He also authorised the general officer commanding Cork to issue orders for the holding of military courts such as might be necessary. In May 1921, the appellants (civilians) were sentenced to death by a military court for the unauthorised carrying of arms. However, since the sentencing body was not a court or judicial tribunal in any legal sense according to the Judicial Committee of the Privy Council, it did not see how it could review any decision it made. Cave LC stated:

The so-called 'military court'... was not and did not claim to be a court or judicial tribunal in any legal sense of those terms. It was not a court martial, that is to say, a tribunal regularly constituted under military law, but a body of military officers entrusted by the commanding officer with the duty of enquiring into certain alleged breaches of his commands contained in the proclamation, and of advising him as to the manner in which he should deal with the offences, and its 'sentences' if confirmed, will derive their force not from the decisions of the military court, but from the officer commanding his Majesty's forces in the field. Its true position was described by Lord Halsbury in Tilonko (see above)... ${ }^{239}$

One would assert that this logic - principally emanating from Lord Halsburyin Tilonko - is flawed.

- When civilians are tried by a military court or tribunal for what might rightly be called criminal offences (even if not specifically termed as such) that body is purporting to act as a 'court', ${ }^{240}$

- Further, since all criminal courts can only emanate from the Crown or pursuant to legislation - these military courts are purporting to act in a judicial capacity. As such, they should be subject to the oversight of the higher civil courts (for example, decisions of the Court of Chivalry are subject to appeal to the Judicial Committee of the Privy Council). ${ }^{241}$

It should also be noted that, in Tilonko (1907), - whether the military court was a court as such (or not) was irrelevant, since legislation provided for the legality of its sentences in any case. ${ }^{242}$ The effect of letting military courts do as they like is to effectively annul the general law. Thus, a jurist, Earle Richards, commenting on the Marais case (1902) opined:

To suspend the law in such circumstances is in general to annul it altogether. To refuse to interfere at any rate in the case of a prisoner condemned to death is not suspension of law but abrogation; it is not a postponement of justice but a denial of the only remedy. ${ }^{243}$

One would agree:

martial or courts at all. They are merely committees formed for the purpose of carrying into execution the discretionary power assumed by the Government.' See also Forsyth, n 5, 560 (not courts, mere committees).

${ }^{239}$ Clifford v O'Sullivan [1921] 2 AC 570 at 581 . At 583 'it is plain that it is in law not a court or judicial tribunal of any kind.'

${ }^{240}$ Tytler, n 30, 109 refers to a 'Court martial, which is in the highest sense a court of honour, are themselves appointed the sole judges, or rather the legislators: For it is in their breasts to define the crime, as well as to award the punishment.'

${ }^{241}$ Verbatim Report of the Case in the High Court of Chivalry of the Lord Mayor, Aldermen and Citizens of Manchester v The Manchester Palace of Varieties Limited on Tuesday, 21 December, 1954 (The Heraldry Society 1955). Goddard CJ suggested that appeal would lie to the Judicial Commitee of the Privy Council, see p 53.See also Manchester Corp v Manchester Palace of Varieties [1955] P 133. Courts martial operating under Crown articles of war were subject to appeal to the king's bench, see Sullivan (writing in 1779), n 94, 37. See also ibid, p 3 'the power of the crown, an unlimited power to create crimes, and annex punishments to them.'

242 [1907] AC 93 at 95 per Halsbury LC, 'An Act of Parliament has been passed in Natal which in terms enacts the legality of the sentences in question, and provides that they shall be deemed to be sentences passed in the regular and ordinary course of criminal jurisdiction. This Board has no power to review these sentences, or to inquire into the propriety or impropriety of passing such an Act of Parliament. The only thing for persons who are subject to such an Act of Parliament to do is to obey.' (italics supplied).

${ }^{243}$ Earle Richards, n 19, 40-1. Bradley \& Ewing, n 16, 634 commenting on the Clifford $v$ Sullivan case [n 239]'The House of Lords regarded the military tribunal in question, which was not a regularly constituted court-martial, as merely an advisory committee of officers to assist the commander in chief; moreover its duties had already been completed...It followed that the army's decision to take the life of a citizen did not become subject to judicial control merely because an informal hearing had been given to the civilian by a military tribunal.' 
- The Court of Chivalry, originally, only applied to the execution of men on the actual battle field, because force - not law - there prevailed, as a matter of fact and necessity. This principle of necessity was then illegally extended to the summary trial and execution of prisoners off the battle field, ${ }^{244}$

- More recently, it was extended - in the colonies - to the application of military justice to civilians after open resistance had ended. This was resisted by persons such as Cockburn CJ in $R v$ Brand and Nelson (1867);

- In the Boer war and in Irish cases in 1902 and 1920, the courts effectively abandoned civilians to military justice - even though the courts were (physically) still open. This was quite wrong and an abdication of responsibility.

However, these cases do establish that - at least by 1920 - martial law can only be applied to civilians by virtue of the Crown prerogative (if at all) if there is a state of actual war existing and the courts - although open - are not able to handle these matters as normal criminal cases.

In conclusion, today, the Crown prerogative to impose martial law on civilians could only apply in war time (ie. foreign invasion or civil war) and not in the case of riots and rebellion. In the latter case, there is also confusion with two other Crown prerogatives concerning: (i) emergencies; and (ii) maintenance of the peace. This is now considered.

\section{Confusion between Martial Law and Crown Prerogatives to Act in an Emergency and to Keep the Peace}

There is considerable confusion in legal analysis (especially in the $19^{\text {th }}$ century) between martial law and other Crown prerogatives - notably the right of the Crown to:

- act in an emergency; and

- $\quad$ keep the peace.

This is, perhaps, not that surprising since martial law has not been applied in England since 1627 (with some exceptions). Thus, it is understandable how it might be confused with situations where the military have been called in to deal with large riots and other major social disturbances. Examples of confusion in separating out these distinct prerogatives may be seen in writers such as Dicey and Stephen. Thus, Dicey (in 1948) - likely following Stephen (writing in 1883) - created a new definition of martial law - confusing it with these other prerogatives. Dicey stated:

Martial law is sometimes employed as a name for the common law right of the Crown and its servants to repel force by force in the case of invasion, insurrection, riot, or generally of any violent resistance to the law. [ie. to act in an emergency]. This right, or power, is essential to the very existence of orderly government, and is most assuredly recognised in the most ample manner by the law of England. The Crown has the right to put down breaches of the peace. ${ }^{245}$ [ie. to keep the peace].

Today, one would assert the courts would clearly distinguish between these prerogatives and martial law - which only applies where military law is imposed on civilians in war time. Thus, martial law does not occur simply when the military is used to quell riots and civil disturbances. As to these other prerogatives, and why they are different to martial law:

\subsection{Crown Prerogative - To Act in Emergencies}

Halsbury states:

The Crown has the same power as a private individual of taking all measures which are absolutely and immediately necessary for the purpose of dealing with an invasion or other emergency. ${ }^{246}$ The Crown

\footnotetext{
${ }^{244}$ See $\mathrm{n} 118$.

${ }^{245}$ Dicey, n 16, 288. Heuston, n 16, 151 '[martial law] means the right to use force against force within the realm in order to suppress civil disorder.' Phillips \& Jackson, n 16 refers to one interpretation of martial law being to 'the common right and duty to maintain public order by the exercise of any degree of necessary force in time of invasion, rebellion, insurrection or riot.' See also Gross \& Aolain, n 19, 32-3.

${ }^{246}$ Halsbury, vol 8(2), para 820 refers to $R v$ Hampden (1637) 3 ST 826 at 975, 1011-3. Also, to the Report of the Inquiry into the Export of Defence Equipment and Dual-Use Goods to Iraq and Related Prosecutions (HC Paper, 1995-6, no 115). For the exercise of the Crown prerogative in past times, see Bradley \& Ewing, n 16, 635-7. For argument whether this is a prerogative or a common law power see Holdsworth, n 55, vol 10, 365.
} 
further has prerogative power to take action to maintain the peace ${ }^{247} \ldots$ the Crown has certain discretionary powers in time of war or emergency, for example the power of requisitioning ships. ${ }^{248}$

Thus, two prerogatives are involved; the first is the right of the Crown to undertake certain extraordinary measures to deal with an emergency. This would include emergencies arising from foreign invasion or major civil disturbance. However, this prerogative is separate to the application of martial law. Nor can it be used to justify the application of martial law in peacetime (including riots and rebellions) since the same is illegal by virtue of the Petition of Right 1627. Bradley and Ewing, in their text on Constitutional and Administrative Law (14 ${ }^{\text {th }}$ ed., 2007) state:

In the present context, martial law refers to an emergency amounting to a state of war when the military may impose restrictions and regulations on citizens in their own country. In such a situation of civil war or insurrection, the ordinary functioning of the courts gives way before the tasks of the military in restoring the conditions which make normal government possible.

Unlike the use of armed force for restoring order during riots, when the military are subject to direction by the civil authorities and to control by the courts, if excessive force is used, under martial law the military authorities are (for the time being) the sole judges of the steps that should be taken. These steps might involve taking drastic steps against civilians, for example, the removal of life, liberty or property without due process of law, but possibly accompanied by the creation of military tribunals to administer summary justice. Such tribunals are not to be confused with the courts - martial which regularly administer military law. ${ }^{249}$ (italics supplied and wording divided for ease of reference)

One would agree with the basic tenor of this. However, martial law is best seen as a distinct prerogative, part of a larger Crown prerogative to act in the case of emergency. And the latter, itself, is part of the most basic Crown prerogative of all - the duty to maintain the peace. Thus, Halsbury states, as to the prerogative to act in an emergency:

Whether this power of using extraordinary measures is really a prerogative of the Crown or whether it is merely an example of the common law right and duty of all, ruler and subject alike, to use the amount of force necessary to suppress disorder, is not quite free from doubt..$^{250}$

\subsection{Crown Prerogative - To Maintain the Peace}

One would assert that this Crown prerogative to maintain the king's (or queen's) peace is the earliest, and most basic, Crown prerogative of all. ${ }^{251}$ However, this prerogative is not martial law, as Cockburn CJ noted in his address to the jury in $R v$ Nelson and Brand (1867):

\footnotetext{
${ }^{247}$ Harrison v Bush (1855) 5 E \& B 344 (119 ER 509) at 353 per Lord Campbell CJ (to the Secretary of State of the Home Department belongs the prerogative to maintain the peace in the kingdom, with the superintendence of the administration of justice as far as the royal prerogative is involved in it).

${ }^{248}$ Halsbury, n 13, vol 8(2), para 820.

${ }^{249}$ Bradley \& Ewing, n 16, 632.

${ }^{250}$ Halsbury, n 13, vol 8(2), para 821 refers to $R v$ Pinney (1832) 3 B \& Ad 947 (172 ER 962)(the general rules of law require of magistrates, at the time of a riot, that they should keep the peace, and restrain the rioters, and pursue and take them; and to enable them to do this, they may call on all the king's subjects to assist them). Also, to a Report of the Committee appointed to Inquire into the Circumstances connected with the Disturbances at Featherstone on the $7^{\text {th }}$ September 1893 (the Featherston Riots, 1893-94 (Cd 7234, 1893). See also Forsyth, n 5, 214-6 and Scott, n 19, 265-81 (for a useful summary of military involvement in riots in England).Halsbury, vol 8(2), para 821 refers to the Featherstone riots of $7^{\text {th }}$ September, 1893. However, this was not a case where martial law was applied. In this case, 'locked out' miners rioted against a small number of troops (3 officers and 26 men) brought in to restore order. The Riot Act 1714 was read, giving the crowd one hour to disperse. However, the crowd growing ugly, the troops fired on them within the hour, injuring various people, two of whom died. A report of a Committee was issued (Bowen LJ was chairman of the Committee). The Report says, 9 'By the law of this country everyone is bound to aid in the suppression of riotous assemblages. The degree of force, however, which may lawfully be used in their suppression depends on the nature of each riot, for the force used must always be moderated and proportioned to the circumstances of the case and to the end to be attained...Officers and soldiers are under no special privileges and subject to no special responsibilities as regards the principle of the law.' The Report felt that the force used by the soldiers was reasonable in the circumstances. It recommended that the law on the suppression of riot should be consolidated and codified. Forsyth, n 5, 196 (quoting a Legal Opinion of 1824) 'If the military, obeying the lawful commands of the magistrate, be so assailed that resistance cannot be effectually made without sacrificing the lives of the rioters, they would in law be justified in so doing. It is obvious, therefore, that each case must depend upon its own circumstances, and that the only rule that can be given is that the force, to be legal and justifiable, must in every instance, as far as the infirmity of human passion will admit, be governed by what the necessity of the particular occasion may require.' See also Holdsworth, n 55, vol 10, 709-13 and n 19, 130.
} 
It is a right paramount to all law, and which the law of every civilised country recognises - that life may be protected or crime prevented by the immediate application of any amount of force which, under the circumstances, may be necessary. ${ }^{252}$

This most basic prerogative - founded on necessity (salus populi suprema est lex - the safety of the people is the supreme law) - originated (at least) from Anglo - Saxon times when all able-bodied men could be summoned by the sovereign to fend off foreign invasion or internal rebellion. It was part of the 'three necessities' (trinoda necessitas) imposed on the same. ${ }^{253}$

- The prerogative to act in the case of emergency is a sub-set of this most basic of Crown prerogatives - the right of the Crown to call on its citizens to protect society (the common weal). And, doubtless, one specific aspect of both of these prerogatives is the prerogative of the Crown to impose martial law. However, the former does not necessarily involve the latter - which is why they must be distinguished;

- Even in olden times, in the case of riots or emergencies, martial law was not necessarily imposed. It was only imposed by the Crown (by way of proclamation or commission) in rare situations. Thus, if the Crown prerogative to impose martial law is abolished, this will affect these other prerogatives only to the (very limited) extent they embrace martial law. It will not prevent, for example, the military being called in to quell domestic disturbances; or the right of the Crown to requisition ships etc.

Finally, the European Convention for the Protection of Human Rights and Fundamental Freedoms (1950) (ECHR), incorporated into English domestic law by the Human Rights Act 1998, art 2(2)@ provides:

(1) Everyone's right to life shall be protected by law. No one shall be deprived of his life intentionally save in the execution of a sentence of a court following his conviction of a crime for which this penalty is provided by law.

(2) Deprivation of life shall not be regarded as inflicted in contravention of this article when it results from the use of force which is no more than absolutely necessary (a) in defence of any person from unlawful violence; (b) in order to effect a lawful arrest or to prevent the escape of a person lawfully detained; (c) in action lawfully taken for the purpose of quelling a riot or insurrection. (italics supplied).

Thus, art 2(c) justifies the use of force (including, where necessary, the deprivation of life) in order to quell riots or insurrections (rebellions) and the ECHR does not treat the same as martial law.

In conclusion, martial law is a sub-set of two wider Crown prerogatives - to take measures to deal with emergencies and to maintain the peace. ${ }^{254}$ However, the latter have been (invariably) exercised down the centuries, in most cases, without the need to also invoke martial law - which is restricted to the application of military law to civilians. As it is, the ECHR does not treat the application of force needed to quell riots or rebellions as martial law. Finally, the Crown prerogative to impose martial law has, in modern times, been superceded (it is asserted) by legislation. This is now considered.

\section{Martial Law and Emergency Legislation}

\subsection{Emergency Powers Act 1920 (rep)}

In the $20^{\text {th }}$ century, legislation was enacted to deal with emergencies - such as to almost obviate the need to resort to any Crown prerogative to impose martial law in any case. Thus, the Emergency Powers Act 1920, s 1(1) provided that - if it appeared to the sovereign that events of a specified nature had occurred - or were about to occur - he

\footnotetext{
${ }^{251}$ Finlason, n 19, 73 'There is no prerogative of the Crown so ancient, so important, and so undoubted, as that of preserving the peace of the realm. It is one of those things which prove themselves, which rest on first principles, and arise out of a manifest and unavoidable necessity. It lies at the very origin of society, and is the main object for which Government exists, and the law was established...It is ...the first and most sacred duty of the Crown, and it was its earliest and most important prerogative, for it involves, as a necessary consequence, the prerogative of levying war, or using armed force, if necessary, for the purpose.'

${ }^{252}$ Brand \& Nelson, n 37, 85. See also Forsyth, n 5, p 553 (martial law applied improperly to the right of Crownto repel force with force).

${ }^{253}$ Hallam, n 5, vol 2, 132, 'By the Anglo-Saxon laws, or rather by one of the primary and indispensable conditions of political society, every freeholder, if not every freeman, was bound to defend his country against hostile invasion.' Ibid, 134-5 'In the imminent peril of hostile, in the case of intestine rebellion, there seems to be no room for doubt that the king, who could call on his subjects to bear arms for their country and laws, could oblige them to that necessary discipline and previous training, without which their service would be unavailing.' Childers (n 213), at 14 per O'Connor MR 'Suprema lex, salus populi must be the guiding principle when the civil law has failed. Force then becomes the only remedy, and those to whom the task is committed must be the sole judges how it should be exercised.'

${ }^{254}$ A good way (one would suggest) to perceive this is to compare these prerogatives to a Russian doll. The largest is the Crown prerogative to maintain the peace. Inside it, is a lesser prerogative to act in the case of emergencies. And inside it, is a prerogative to impose martial law.
} 
might, by proclamation, declare a state of emergency. ${ }^{255}$ The events envisaged were those of such a nature as to be calculated - by interfering with the supply and distribution of food, water, fuel or light, or with the means of locomotion - to deprive the community (or a substantial portion of it) of the essentials of life. ${ }^{256}$ Once an emergency had been declared, it had to be communicated to Parliament who must sit. ${ }^{257}$

- Further, the Act provided that, where a proclamation had been made, regulations might also be made ${ }^{258}$ which might confer (or impose) on a Secretary of State (or other Government department or any other person in the service of the Crown or acting on behalf of the Crown) such powers and duties as the Crown might deem necessary for, inter alia, the preservation of the peace and other purposes essential to the public safety and life of the community. ${ }^{259}$ However, such regulations might not impose any form of compulsory service or industrial conscription; ${ }^{260}$

- Regulations might also provide for the trial of civilians by courts of summary jurisdiction. The maximum penalty was imprisonment for 3 months or a fine not exceeding level 5 on the standard scale or both. ${ }^{261}$ The Act provided that the existing procedure in criminal cases was not to be altered; nor was there to be any fine or imprisonment without trial. ${ }^{262}$

This legislation - replaced by the Civil Contingencies Act 2004 (see below) - is useful since it indicates that - even in emergencies - the legislative intent, since 1920, has been to use criminal courts of summary jurisdiction - and not military courts or tribunals - to try civilians. Since this Act specifically refers to trying civilians in such courts, it supersedes (to the extent of the application of the Act) any attempt to try civilians in military courts pursuant to the exercise of the Crown prerogative.

\subsection{Emergency Powers (Defense) Acts 1939 \& 1940}

Separate to the above Act, during World War II (1939-45), power was granted under the Emergency Powers (Defence) Acts 1939 and 1940 to establish special civilian courts for the trial of offenders in areas within the UK where - by reason of actual (or apprehended) enemy action - the military situation might be such that criminal justice could not be administered by the ordinary courts. The power was never exercised and it expired on $23 \mathrm{Feb}$ $1946{ }^{263}$ This legislative power also manifests a clear legislative intent to use special civilian courts to try civilians - even during wartime - obviating any need to resort to a Crown prerogative to invoke martial law in order to submit civilians to military courts.

\subsection{Civil Contingencies Act $2004^{264}$}

This Act covers emergencies. It is wider in ambit that the Act of 1920 (see 7.1 above). It defines an emergency ${ }^{265}$ to include war and terrorism. ${ }^{266}$ In an emergency, regulations can be made without a state of emergency having to be declared - or Parliament having to agree to the same - although there is an opportunity for Parliament to consider any regulations made thereunder. ${ }^{267}$ The ambit of these emergency regulations is extensive ${ }^{268}$ and they

\footnotetext{
${ }^{255}$ Halsbury, n 13, vol 8(2), para 822. See also Phillips \& Jackson, n 16, 400-1 and Ewing \& Gearty, n 222, chs 2 \& 4.

256 Ibid.

257 'Ibid.'Where a proclamation of emergency has been made, the occasion of it must be forthwith communicated to Parliament. If Parliament is at the time separated by such adjournment or prorogation as will not expire within five days, a proclamation must be issued for the meeting of Parliament within five days, and Parliament must meet and sit accordingly.'

${ }^{258}$ Ibid, 'Such regulations must be laid before Parliament as soon as may be after they are made, and are not to continue in force after the expiration of seven days from the time when they are so laid unless a resolution is passed by both Houses providing for their continuance.' See also, Emergency Powers Act 1920, s 2(2).

259 Ibid.

${ }^{260}$ Ibid. Also, Emergency Powers Act 1920, s 2 (1).

${ }^{261}$ Ibid. Level 5 is $£ 5,000$.

${ }^{262}$ Ibid.

${ }^{263}$ Bradley \& Ewing, n 16, p 633. In the case of the First World War (1914-18) the Defence of the Realm Act authorized, for a few months, the trial of civilians by court martial for offences against the defence regulations. Ibid. However, this authority was much circumscribed in any case. See Cook (1918), 191-200.See also Phillips \& Jackson, n 16, 403. For the Emergency Powers (Defence) Acts, see ibid, 403-4. Also, the Emergency Powers (Defence) (No 2) Act 1940 where civilians could be tried 'by...special courts, not being courts martial.'

${ }^{264}$ See generally, Bradley \& Ewing, n 16, 637-9.

${ }^{265}$ Civil Contingencies Act 1920, s 19.

${ }^{266}$ Ibid, ss 1 \& 19(1).

267 Ibid, s 20.

268 Ibid, s 22.
} 
include the power to confer jurisdiction on a court or tribunal, including one established pursuant to the regulations. ${ }^{269}$ The regulations can also create new criminal offences arising from a failure to comply with the regulations. However, s 23(4) of the Act provides that such regulations may not create a criminal offence other than one which:

- $\quad$ is of the kind described in section $22(3)(\mathrm{i}) ;^{270}$

- is triable only before a magistrates' court; or

- is punishable with imprisonment for a period exceeding three months (or a fine exceeding level 5 on the standard scale); or

- will not alter procedure in relation to criminal proceedings.

Further, such offences may not contravene the Human Rights Act 1998 (see below) or require a person (or enable a person) to provide military service. The net effect of all this - it is asserted - is to replace the need to rely on any Crown prerogative to impose military law on civilians in wartime - including subjecting civilians to military courts. This Act has effectively supplanted it, since it specifically covers 'war' and - more importantly - it provides for civil courts to deal with criminal offences arising out of emergency and war time regulations. Thus, this legislation (like the others discussed) effectively rules out (as well as the need for) military courts judging civilians even in war time.

\subsection{Human Rights Act 1998}

Finally, there are various articles of the ECHR (articles 5-7) which militate against martial law, since the latter is unlikely to satisfy their requirements. Article 5provides, inter alia:

(1) Everyone has the right to liberty and security of person. No one shall be deprived of his liberty save in the following cases and in accordance with a procedure prescribed by law:

(a) The lawful detention of a person after conviction by a competent court;

(b) The lawful arrest or detention of a person for non-compliance with the lawful order of a court or in order to secure the fulfilment of any obligation prescribed by law;

(c) The lawful arrest or detention of a person effected for the purpose of bringing him before the competent legal authority on suspicion of a having committed an offence or when it is reasonably considered necessary to prevent his committing an offence or fleeing after having done so;

(2)...

(3) Everyone arrested or detained in accordance with the provisions of paragraph $1 \mathrm{v}$ of this article shall be brought promptly before a judge or other officer authorised by law to exercise judicial power and shall be entitled to trial within a reasonable time or to release pending trial. Release may be conditioned by guarantees to appear for trial.

(4) Everyone who is deprived of his liberty by arrest or detention shall be entitled to take proceedings by which the lawfulness of his detention shall be decided speedily by a court and his release ordered if the detention is not lawful.

Article 6 provides:

(1) In the determination of... any criminal charge against him, everyone is entitled to a fair and public hearing within a reasonable time by an independent and impartial tribunal established by law. Judgment shall be pronounced publicly...

(2) Everyone charged with a criminal offence shall be presumed innocent until proved guilty;

(3) Everyone charged with an offence has the minimum rights:

\footnotetext{
269 Ibid, s 22(3).

${ }^{270}$ Section 22 (3) provides that emergency regulations may make provision of any kind that could be made by Act of Parliament or by the exercise of the Royal Prerogative; in particular, regulations may... (i) create an offence of - (i) failing to comply with a provision of the regulations; (ii) failing to comply with a direction or order given or made under the regulations; (iii) obstructing a person in the performance of a function under or by virtue of the regulations...' (italics supplied). Even if the Crown, purporting to exercise the Royal Prerogative, sought to impose martial law, it is restricted by the nature of the offences it can create and it can be one other than one which is tribal before a magistrates' court.
} 
(a) To be informed promptly in a language which he understands and in detail, of the nature and cause of the accusation against him;

(b) To have adequate time and facilities for the preparation of his defence;

(c) To defend himself in person or through legal assistance of his own choosing or, if he has not sufficient means to pay for legal assistance, to be given it free when the interests of justice so require;

(d) To examine or have examined witnesses against him and to obtain the attendance and examination of witnesses on his behalf under the same conditions as witnesses against him;

(e) To have the free assistance of an interpreter if he cannot understand or speak the language used in court.

Article 7 provides:

No one shall be held guilty of any criminal offence on account of any act or omission which did not constitute a criminal offence under national or international law at the time when it was committed. Nor shall a heavier penalty be imposed than the one that was applicable at the time the criminal offence was committed.

The trial of a civilian by a military court during peacetime would not likely meet a number of these requirements:

- Article 5 provides that a person shall not be derived of their liberty unless in respect of the 'lawful arrest or detention of a person...for the purpose of bringing him before the competent legal authority on suspicion of a having committed an offence'. Further, such person must be 'brought promptly before a judge or other officer authorised by law to exercise judicial power'. He must also be tried before 'an independent and impartial tribunal established by law;'

- A military tribunal will only be a 'competent legal authority' if the Crown proclaims it as such, pursuant to martial law. ${ }^{271}$ So too, the authority of any military personnel to exercise 'judicial power' since military law does not otherwise provide for the trial of civilians by court martial. However, since martial law is 'no' law and military tribunals summoned under martial law are no 'courts' (as established by cases of high English authority, see 5.2.1 \& 5.2.2), it is dubious whether they can be argued to exercise 'judicial' power. Instead, they are exercising a non-judicial power 'on the field of battle' as it were, where force and not law prevails;

- Article 6 requires 'an independent and impartial tribunal established by law.' In the case of a military court, military officers - untrained in law and assembled to dispense summary justice - will be unlikely to be 'independent and impartial'. Indeed, they will be likely judging persons who have perpetrated (or intended to perpetrate) acts of violence against them and, thus, be emotionally involved. Further, it is unlikely that the conditions of Article 6(3) as to the trial process will be met.

In conclusion, it is unlikely the trial of a civilian by a military tribunal under martial law in peacetime would satisfy the above articles of the ECHR. As to war time or great civil commotion, Article 15 provides:

(1) In time of war or other public emergency threatening the life of the nation any High Contracting Party may take measures derogating from its obligations under this Convention to the extent strictly required by the exigencies of the situation, provided that such measures are not inconsistent with its other obligations under international law;

(2) No derogation from Article 2, except in respect of deaths resulting from lawful acts of war, or from Articles 3, 4 (paragraph 1), and 7 shall be made under this provision; ${ }^{272}$

(3) Any High Contracting Party availing itself of this right of derogation shall keep the Secretary General of the Council of Europe fully informed of the measures which it has taken and the reasons therefore. It shall also inform the Secretary General of the Council of Europe when such measures have ceased to operate and the provisions of the Convention are again being fully executed.

Would martial law be 'required by the exigencies of the situation' in the case of war time or emergency? One would argue not, since the Civil Contingencies Act 2004 (and prior legislation) have made it clear that - even

\footnotetext{
271 This would seem to be the only way which the Crown could empower, since commissions are now obsolete.

${ }^{272}$ Article 2(1) provides that everyone's life shall be protected by law and that no one shall be deprived of his life intentionally save in the execution of a sentence of a court following his conviction of a crime for which this penalty is provided by law. Article 3 prohibits torture. Article 4 (1) prohibits slavery and forced labour. For Article 7, see text.
} 
during war and emergency - civilians should be tried by civil courts and that new criminal offences can only be created in very limited circumstances (see 7.3).

In conclusion, the Civil Contingencies Act 2004 makes provision for the government to pass emergency regulations in an emergency which includes war. Such regulations include the ability to confer jurisdiction on courts (including ones established under the regulations). However, the ability to alter criminal procedure is limited and new criminal offences must be such as to be triable in the magistrates' court in England and Wales. Thus, the need for the Crown to exercise its prerogative to impose martial law on civilians in war time and to submit them to military courts (which are not proper 'courts' in the general sense of the word) is avoidedeffectively making obsolete such a prerogative.

\section{Abolishing the Crown Prerogative to Impose Martial Law}

Today, martial law can only comprise a reference to military law $^{273}$ being imposed on civilians. ${ }^{274}$ The Petition of Right 1627, section 8 prevents martial law being imposed on civilians in peacetime, which includes all riots and civil disturbances. Thus, today, at most, the Crown only has a prerogative to impose martial law on civilians in war time and when the courts are not otherwise open. War time would cover both foreign invasion and civil war. The essential issue, therefore, is whether the Crown should have and/or needs this prerogative. In the past, subjecting civilians to martial law was, principally to enable the Crown:

(a) To impose the death penalty in circumstances not otherwise permitted by the common law. This is no longer relevant since the death penalty has been abolished for all purposes anyway;

(b) To subject civilians to harsher military punishments (whipping etc). ${ }^{275}$ This is also no longer relevant since they have long ended;

(c) To try civilians in military courts - mainly to enable (a) and (b) to be applied. ${ }^{276}$

Thus, the main purposes of subjecting civilians to martial (military) law in the past no longer apply. Be that as it may, one would assert that such a draconian power has no place in a modern democracy and that - if ever required in the future - it should be applied by Parliament and not by the Crown and unaccountable Crown servants. The following may also be noted:

- Legislation in 1920 and World War II - as well as the Civil Contingencies Act 2004 - envisaged (and envisages) civilians being tried in civil courts and not military ones - even in war time situations. The latter, in particular, supplants the application of any Crown prerogative to impose martial law with the intent to subject civilians to military courts;

- The Crown prerogative to impose martial law does not apply where the king's criminal courts are open. Thus, it was not required in two World Wars, the courts remaining open. There is no reason to envisage any change in any future wars and - if the courts do have to close because of fighting - Parliament can make provision for military law being extended to civilians if required;

- The history of the implementation of martial law by the Crown down the centuries has been uniformly dreadful since it was grossly extended beyond the general premise that courts (per force) cannot sit on battle fields. Its extension to permit the military to try (and execute) rebels off the field of battle - often without trial or a perfunctory trial - was not law but savagery which has no place in modern society. English history provides vivid proof that - where the usual criminal courts abstain or are too scared to protect the rights of civilians and leave them to military personnel - the inexperience of the latter (and, doubtless, a high degree of emotionalism) has resulted in the gross abuses of human rights and no impartial trial. ${ }^{277}$

\footnotetext{
${ }^{273}$ Bradley \& Ewing, n 16, 632 'In former times martial law included what is now called military law.'

${ }^{274}$ The armed forces are governed by military law both in war, and peace, time.

${ }^{275}$ See $\mathrm{n} 81$.

${ }^{276}$ Earle Richards, n 19, 133 'that species of martial law which consists of trial by military courts, or infliction of penalties without the sanction of a court of law, to which the term is often restricted.' It may be noted that the principle purpose (and result) of the application of martial law in the colonies and in Ireland was to enable alleged rebels to be tried summarily before military personnel assembled as an ad hoc court and then executed by hanging or firing squad.

${ }^{277}$ For the Ceylon rebellion of 1848, see Mills, n 194, 194-6. See also Brand \& Nelson, n 37, 160-2 (re insurrections in Jamaica) 'if, on martial law being proclaimed, a man can lawfully be thus tried, condemned, and sacrificed, such of things is a scandal and a reproach to the institutions of this great and free country.' Finlason, n 19, 5 (on the Irish rebellion of 1796) 'The rebellion was in Wexford, but Mr Wright was flogged,
} 
In conclusion, there are no good grounds for subjecting civilians to martial law during war time and - if it is ever were required - Parliament, and not the Crown, should impose this. As it is, the right to impose martial law is, ultimately, based on a very flimsy ground, summed up in the maxim said to have been contained in the final paragraph of the Roman Twelve Tables:

Et silent leges inter arma [and amidst the clash of arms the laws are silent] ${ }^{278}$

As with all maxims this is pithy and memorable. However, as with many maxims in the legal context, it is also a tabula in naufragio (to use another maxim). Further, it betrays a lie - that the law, must be, in the end, subservient to war. However, as with many maxims one would suggest there is a better - and a greater one - more suitable to modern times. One on which civilised society and democracy has been built. Fiat Justicia! Let justice be done! Thus, it is absolutely essential, in a modern democracy, that civilians should be tried fairly and impartially in their own courts - even at personal risk to the lives of criminal judges themselves. The courts should remain open to the last - even when all the other bulwarks of democracy topple and fail. This should have happened in Ireland in the 1920 's. Mercifully, it did during the Troubles. ${ }^{279}$ Otherwise, civilians are exposed to a military justice which history has vividly proved can be wholly arbitrary, summary and unjust. What would be the consequences of abolishing the Crown prerogative to impose martial law? Very few, for the following reasons:

(a) Martial law is severely restricted in ambit anyway, only applying in war time and when the courts are not open. However, the Civil Contingencies Act 2004 makes provision for the use of civil courts to try civilians even during war. In any case, Parliament could legislate to apply martial law, if so required;

(b) It would only affect the other Crown prerogatives to act in an emergency and to maintain the peace to the extent of (a). ${ }^{280}$ This is negligible, in practice, since martial law has not been imposed in England since 1627 (with a few exceptions up to 1688).

Abolition of this Crown prerogative would also clear out a large amount of bad law. And it would make re-dress for the fact that - at various periods in English history - the courts failed to protect the rights of civilians when they most needed their aid.

In conclusion, the Crown prerogative to impose martial law is obsolete and unnecessary. The imposition of military law on civilians is too detrimental to human rights to be left to so uncertain a prerogative. It should be abolished and - if ever required in future - it should be left to Parliament to curtail one of the most fundamental liberties of the individual - the right to be tried in the king's courts by the general laws of the realm.

\section{Crown Prerogative to Impress Subjects in the Case of Sudden Invasion or Dangerous Rebellion ${ }^{281}$}

Halsbury states:

The Crown may also demand, and is entitled to, the personal services of every man capable of bearing arms in case of sudden invasion or dangerous rebellion, but except on such occasions it has no power, unless such a power is conferred by statute, to compel enlistment.(italics supplied) ${ }^{282}$

The authority for this proposition is scant. Further, it is an unwarranted extension of the Crown prerogative to forcibly impress subjects for the navy - which prerogative has never been abolished although it is clearly obsolete. This proposition of Halsbury derives from an observation made by Sir Michael Foster in Broadfoot (1743) ${ }^{283}$ where he considered the legal basis for the impressments of mariners as sailors. Foster stated:

\footnotetext{
without any military authority in Tipperary; Wolf Tone [n 178] was tried in Dublin, where there was no martial law, and the courts were sitting; and with...Mr Grogan [n 181]...if it was after the rebellion was thoroughly quelled, it was therefore illegal.'

${ }^{278}$ See n 155. Cicero in Pro Milone 'silent enim leges inter arma'. Scott, n 19, 382 'The universal practice of all nations has been to give supremacy to the military commander in all sieges. 'Inter arma silent leges', is then a maxim universally admitted. The public safety in that case imperiously requires that the orders of the commander of the troops should be obeyed...' See also Childers (n 213), at p 14 per O'Connor MR 'Inter arma silent leges is a maxim two thousand years old, and has come to use from the Romans.'

${ }^{279}$ It is a great tribute to the personal courage of judges (and judicial personnel) in Northern Ireland that the courts continued to sit throughout the Troubles arising from 1969.

280 Thus, it would not prevent the Crown using troops to help quell riots and major civil disturbance. The degree of force they can use must be reasonable in the circumstances. Further, in the case of open armed resistance against troops, it is reasonable for them to shoot in self-defence.

${ }^{281}$ See McBain $\mathrm{n} 1$ which considers the Crown prerogative to impress mariners into the royal navy. Also, Butler, $\mathrm{n} 36$.

${ }^{282}$ Halsbury, n 13, vol 8(2), para 819.

${ }^{283} R v$ Broadfoot (1743) Foster 154 (168 ER 76). The reference is to Mr Sarjeant Foster, sitting as recorder at the sessions of goal delivery in Bristol. See also $R v$ Tubbs (1776) 2 Cowp 517 (98 ER 1215) per Mansfield CJ at 517 'The power of pressing is founded upon immemorial
} 
I think the Crown hath a right to command the services of these people [ie. to impress mariners into the royal navy], whenever the public safety called for it. The same right that it hath to require the personal service of every man able to bear arms in the case of a sudden invasion or formidable insurrection. The right in both cases is founded on one and the same principle, the necessity of the case in order to the preservation of the whole. ${ }^{284}$ (italics supplied)

A note to this in the English Reports states:

This personal service in cases of extreme necessity is a principal branch of the allegiance every subject owes to the Crown. ${ }^{285}$

Thus, to Foster, the rationale for impressing subjects (that is, compulsorily conscripting them into the armed forces) in the case of 'sudden invasion' or 'formidable insurrection' (which Halsbury re-translates as 'dangerous rebellion') was analogous to the right to impress sailors (mariners) into the royal navy. And that both were predicated on the principal of allegiance to the Crown - as well as the need to preserve public safety. Prior to considering whether the Crown still requires such a prerogative, it is important to note that the legal basis for the Crown prerogative to impress mariners into the navy - as well as to impress male subjects to become soldiers - is flimsy. As a result, to claim that there is a general right of the Crown to impress any British subject who is an 'able bodied man' (but not woman or child) capable of bearing arms is - quite frankly - dubious. It may have been correct in Anglo - Saxon times, when there was a general obligation of trinoda necessitas, ${ }^{286}$ but not today - and not after 1688 when the realm had a permanent standing army to deal with invasions and rebellions.

\subsection{Impressing Sailors into the Royal Navy 287}

In Broadfoot (1753), in respect of the legal right of the Crown to impress mariners into the navy, ${ }^{288}$ Foster admitted there was no legislation in force which permitted $\mathrm{it}^{289}$ nor any case in point. ${ }^{290}$ Instead, he based his argument on 'immemorial usage' at common law - a usage, itself, based on public policy and the defence of the realm. In support of this immemorial usage, Foster referred to mandatory writs and commissions dating from the time of Edward III (1327-77). ${ }^{291}$ A previous article has considered in detail the validity of this argument ${ }^{292}$ and it is not necessary to re-hearse it in detail. Suffice to say that the impressment of sailors (mariners) for the navy, which was bitterly resented over the centuries, was abandoned after 1814 , nearly 200 years ago. ${ }^{293}$ Also, as long ago as 1859, a Royal Commission report on the Manning of the Navy stated:

The evidence of the witnesses, with scarcely an exception, shows that the system of naval impressments, as practised in former wars could not now be successfully enforced. ${ }^{294}$

\footnotetext{
usage allowed for ages... the practice is deduced from that trite maxim of the constitutional law of England, 'that private mischief had better be submitted to, than that public detriment and inconvenience should ensue.'

${ }^{284}$ At 158 . See also at 159 where Foster refers to 'A general immemorial usage not inconsistent with any statute, especially if it be the result of evident necessity and which tended to the public safety, is, I apprehend, part of the common law of England.'

${ }^{285}$ Reference is then made to three pieces of legislation, long repealed viz 11 Hen VII (1495) c 1 (treason); 1 Edw III (1327) st 2 c 5 (military service) and 16 Car 1c 28 (1640)(impressing of soldiers).

${ }^{286}$ See $\mathrm{n} 253$.

${ }^{287}$ See generally, McBain, n 1. Also, Bruce, n 4, 100-1.

${ }^{288}$ Foster made it clear that he was not analyzing the even more uncertain proposition as to whether the Crown had the right to impress non-mariners into the navy. At 157 'We are not at present concerned to inquire, whether persons may be legally pressed into the land service, nor whether landmen may be legally pressed into the sea-service.' See also Butler, $\mathrm{n} 36,5$ (writing in 1771) 'We do not pretend to consider any right which the Government may claim, to press men into the land service; or its right to press into the sea service, other than seamen.' Also, 7, 'in the advanced state of government, which the British nation has reached, personal service neither is nor ought to be, nor can be, the duty of every citizen.'

289 At 168 'I know of no statute now in force, which directly and in express terms empowereth the crown to press mariners into the [naval] service...' See also Blackstone, n 19, vol 1, 407 ' $[\mathrm{N}]$ o statute has expressly declared this power to be in the Crown, though many of them very strongly imply it.'

${ }^{290}$ McBain, n 1, 19.

${ }^{291}$ Ibid, 20. See also Barrington (1766), 209-12.

${ }^{292}$ See McBain, n 1.Impressing in the navy was abused. For example, Charles I (1625-49) impressed common people who refused to pay towards his forced loan of 1626, see Hallam, n 5, vol 1, 383.

293 Ibid, 19.

${ }^{294}$ Ibid.
} 
Thus, the Crown's chances of successful arguing that it retains a general prerogative to forcibly conscript male civilians - some 200 years after it gave up the attempt to do so in the case of civilian sailors - is remote. If ever required, legislation is appropriate - as was used to conscript civilians into the armed forces in World War I (1914-18) and World War II (1939-45). ${ }^{295}$

\subsection{Impressing Subjects into the Army}

Whether the Crown ever had the right to press British subjects into the army is dubious. Chitty, writing in 1820 , thought not. ${ }^{296}$ For his part, in Broadfoot (1743), Foster did not specifically deal with the legal basis for impressing subjects into the army. ${ }^{297}$

- Foster did refer to several pieces of legislation of an early date (now repealed) which (he said) referred to the practice of pressing soldiers for foreign service. ${ }^{298}$ Also, to the pressing of soldiers for service in Ireland. ${ }^{299}$ However, these instances are not relevant to the present case since they were the result of legislation and not the exercise of the Crown prerogative;

- It seems clear Foster was also dubious whether impressment for land service ever existed, due to the system of military tenure which prevailed, at least, since the Norman Conquest in which land was held of the Crown in return for providing military service (see 1). This system ended in $1660 ; ;^{300}$

- This prerogative is far too extensive and nebulous to be legally sustainable. What invasion is 'sudden' and what not? What rebellion is 'dangerous' and what not? Thus, the prerogative should be restricted to warincluding civil war. However, in the case of the latter, the Crown forcibly conscripting men to fight against their fellow countryman would only likely exacerbate the situation - and there is no precedent. Also, how can the courts determine the legitimacy of this prerogative and whether its terms are satisfied? $?^{301}$

As to any Crown right to press in the case of war time or dire necessity, an Act of 1640(repealed) states that:

Whereas by the laws of this realm none of his majesties subjects ought to be impressed or compelled to go out of his country to serve as a soldier in the wars except in the case of necessity or the sudden coming in of strange enemies into the kingdom or except they be otherwise bound by the tenure of their lands or possessions. ${ }^{302}$ (italics supplied)

\footnotetext{
${ }^{295}$ In World War I, the Military Service Act 1916 provided that single men aged 18-41 (later to age 51) were liable to be conscripted unless widowed with children or ministers of religion. Conscription started on 2 March 1916. The Act was extended to married men on $25^{\text {th }}$ May 1916. It ended in 1919. In World War II, the Military Training Act 1939 (later, National Service (Armed Forces) Act 1939) provided that men aged 18-41, not in reserved occupations, could be conscripted to serve in the armed services (army, navy, air force - they could choose which). In 1941, single women between the ages of 20-30 were conscripted (they did not fight but were placed in reserved occupations). Conscription continued, post war, with the National Service Act 1948 (for men aged 17-21). Conscription ended in 1960. In the British Overseas Territories only Bermuda still has conscription. See also Hawtin (1917-18).

${ }^{296}$ Chitty, n 10, 47 noted that, apart from legislation, 'his majesty has no legal power to force anyone to enlist in his armies.' Cf. Barrington, $\mathrm{n}$ 291, 210-1, who refers to 35 Eliz c 4, see n 298.

${ }^{297}$ See $\mathrm{n} 288$.

${ }^{298} R$ v Broadfoot (1743) Foster 154 (168 ER 76), at 175 he referred to 1 Edw III (1327) st 2 c 5 'The king wills that no man from henceforth shall be charged to arm himself, otherwise than he was wont in the time of his progenitors kings of England; and that none be compelled to go out of his shire, but [where necessity requireth and sudden coming] of strange enemies into the realm; and then it shall be done as hath been used in times past for the defence of the realm.' Also, to $25 \mathrm{Edw}$ III (1350) st $5 \mathrm{c} 8$ 'no man shall be constrained to find men at arms, hoblers nor archers, other than those which hold by such services [ie. by virtue of military tenure], if it be not by common assent and grant made in Parliament'.See also Clode, n 19, vol 1, 355 which cites 35 Eliz c 4 (1592) which refers to soldiers and mariners 'having been pressed and in pay for her majesty's service [in 1588]'. However, the reference to pressing mostly likely refers to mariners, not to soldiers. See also Hale (1736), vol 1, 679. Hale was dubious about the right of the Crown to impress. In modern times, regulations under the Civil Contingencies Act 2004 cannot be used to impress, see 7.3.

${ }^{299}$ Hallam, n 5, vol 2, 131 refers to 4 \& 5 Phil \& Mary c 3 (1557) (military service) which, he asserts, 'recognises, as it seems, the right of the Crown to levy men for service in war'. See also Clode, $n$ 19, vol 1, 352-3.

${ }^{300} R v$ Broadfoot (1743) Foster 154 (168 ER 76), at 175. See also ns 28-30.

301 Whether a rebellion is dangerous or not is not really for a judge to decide. It depends on political events and the ability of the police and army to contain the same.

30216 Car I c 28 (1640) (An Act for the better raising and levying of soldiers for the present defence of the kingdoms of England and Ireland). Justices of the Peace and mayors were empowered to raise and impress soldiers by order of the king and both Houses of Parliament. See also Clode, n 19, vol 1, 26; Hallam, n 5, vol 2, 100 and Tytler, n 30, 66-7. For the abolition of pressing by Parliament during the Civil War, see
} 
The words in italics are otiose since military tenure was abolished 1660. Further, in the case of impressment of subjects into the army by virtue of legislation, this ended in $17800^{303}$ So, was there ever a Crown prerogative to impress subjects into the army?

- One would suggest the answer is 'no' - which is why legislation was employed in the few cases this occurred. Therefore, the statement in Halsbury that there is a Crown prerogative to impress any British man capable of bearing arms in the case of 'sudden invasion or dangerous rebellion, ${ }^{, 304}$ is based on little more than the observation of Foster that this prerogative can be exercised in the case of 'sudden invasion or formidable insurrection', itself unsupported save in respect of an Act of 1640 (now repealed) which (it appears from the context) to refer to the obligation of soldiers (not civilians) to serve abroad in the case of 'necessity or the sudden coming of strange enemies into the kingdom';

- Further, when there were rebellions within the realm in the past (see 2) there appears to be little, or no, evidence of the Crown forcibly enlisting men (tenure, indenture and commissions of array being relied on). ${ }^{305}$ And after, 1689 when there was a standing army, professional soldiers were used to deal with the Jacobite uprisings of 1715 and 1745 .

Thus, it is doubted whether the proposition of Halsbury that the Crown has a prerogative to compel the forcible enlistment of civilians in times of sudden foreign invasion, or internal rebellion, holds water. In any case, today, it is unnecessary and would likely be wholly ineffective in practice. For example, if the United Kingdom was suddenly invaded and the military proved ineffective (as well as, one assumes, the police and voluntary enlistees) is it credible that the Crown could force able bodied men to take up arms against their will? One thinks not - not least because the legal right of the Crown to so act is so uncertain. ${ }^{306}$ As it was, in two World Wars, legislation provided for conscription and not reliance on any Crown prerogative.

In conclusion, any Crown prerogative to impress male subjects in the case of 'sudden invasion or dangerous rebellion' should be abolished. It is unnecessary and the matter should be left to legislation if ever required.

\section{Crown Prerogative to Billet ${ }^{307}$}

The word 'billet' - which derives from the French word meaning a 'note' - is a military order to the recipient to provide board, and lodging, for military personnel. ${ }^{308}$ In early medieval times, it was also common for officials of the king's household and important foreign visitors to be billeted in the homes of citizens in the City of London,

Rushworth, n 25, vol 6, 292. Clode, n 19, vol 2, 8 'The impressment of soldiers by the direct orders and under the sole authority of the Crown, absolutely ceased after the revolution of 1688 .'

${ }^{303}$ McBain, n 1, 19. For the recruitment of soldiers prior to this see Clode, n 19, vol 2, ch 15.

304 The epithets 'sudden' and 'dangerous' add nothing. The fact that the invasion is sudden or not, is not a criterion. The fact that the British military would otherwise be overwhelmed, is. Further, 'rebellion' against what? If against the sovereign, it would constitute levying war under the Treason Act 1351 (or conspiracy under the Treason Felony Act 1848). If against Parliament in order to force it to change laws, it would be covered by the Treason Felony Act 1848. There is no reason why military courts should determine such things (in the Jacobite rebellions of 1715 and 1745 it was left to the courts). Further, today, the chance of people rebellion against the sovereign is less than remote, since the sovereign no longer has any power.

${ }^{305}$ See ns 28-34.

${ }^{306}$ One would suggest that large numbers of untrained civilians would also be unnecessary in a modern war and would likely be more of a liability than an asset.

${ }^{307}$ See Clode, n 19, vol 1, ch 11 .

${ }^{308}$ Halsbury, n 13, vol 2(2), para 126. 'To billet' means to require an occupier of a certain kind of premises to provide accommodation in them as quarters for members of her majesty's forces or their vehicles. OED, n 20, (definition of billet (4)), 'An official order requiring the person to whom it is addressed to provide board and lodging for the soldier bearing it. Hence billet-master, the official whose duty it is to make out billets; billet-money, the cost of quartering soldiers.' See generally, McBain, n 140, 96-8 (it discusses billeting in the context of the Petition of Right 1627). 
something much resented. ${ }^{309}$ However, by the18th century, with the expansion of inns (hotels) throughout England, billeting tended to be restricted to them - often to their ruin. ${ }^{310}$

- Under Charles I (1625-49), the Crown prerogative to billet was particularly abused by him. The Petition of Right 1627 (still extant in part)stemmed from the attempt of Charles I to raise the Forced Loan of 1626, to re-plenish the depleted royal coffers; ${ }^{311}$

- One tactic employed to make wealthy people pay this forced loan was to billet troops (mainly soldiers returning from Cadiz) ${ }^{312}$ on them - an unpleasant experience since these soldiers were often unruly and little, or no, payment was made for their lodging. ${ }^{313}$

Thus, the Petition of Right 1627, which petition was granted, in section 8 of the same (still extant), requests that Charles I:

would be pleased to remove the said soldiers and mariners and that your people may not be so burdened in time to come. ${ }^{314}$ (italics supplied)

In short, the Petition enacts that the sovereign will not, in the future, billet 'soldiers and mariners' on the general public. This was confirmed in a proclamation in January 1688 by William III. ${ }^{315}$ However, as Maitland (writing in 1908) has pointed out, the billeting provisions contained in the Petition of Right 1627 were annually suspended. 316 Thus, in more modern times, the Army Act 1881 provided that:

\footnotetext{
309 The marshal of the Royal Household billeted visitors to the coronation of Edward II (1307-27) on London citizens, in their hostels (referring to houses, in this case, as opposed to public inns). See Proclamation of 1308, 'The hostels in the City of London, which were taken by the marshals of our Lord King Edward, son of King Edward, for lodging the great folks, native and foreign, who had come to the coronation of our said Lord the King, on [24 Feb 1308] were, by award of him, our Lord the King, and his council, given up on the Thursday following; it being understood that if the parties occupying them should wish to make any further stay, they were to make recompense to the owner of the house for the same, etc'. See Riley (1868), 64-5.

${ }^{310}$ Burn, n 46, 80-1 (in 1779) refers to 2 Geo III c 20 (1763) s 100 (it limited billeting to inns, livery stables, ale houses, victualling houses and liquor houses).

311 The loan netted about $£ 250,000$. See Rushworth, $n 25$, vol 1, 418-9. At 419 'To the imposition of loan was added, the burden of billeting of soldiers formerly returned from Cadiz, and the moneys to discharge their quarters were for the present levied upon the country, to be repaid out of sums collected upon the general loan.' Samuel, n 27, 49 'Soldiers were billeted in private houses; and under the denomination of loans, large sums were required of the people in the second year of the king's reign, for the assistance of the king of Denmark; and they, who refused to comply with the requisition, were either imprisoned or enrolled for soldiers.'

312 The Cadiz expedition of 1625, an expedition against the Spanish by the English and the Dutch, and masterminded by the Duke of Buckingham, Lord High Admiral, the favourite of Charles I, was a disaster. Returning troops to England were rebellious and disorderly. See also Manning (2006) and Clode, n 19, vol 1, 19-20.

313 Petition of Right 1627, s 6 'And whereas of late great companies of soldiers and mariners have been dispersed into divers counties of the realm, and the inhabitants against their wills have been compelled to receive them into their houses, and there to suffer them to sojourn against the laws and customs of this realm and to the great grievance and vexation of the people.' Charles billeted troops in civilian homes mainly in the South East of England. See also Boynton (1959), 23-40. See also Rushworth, n 25, 540-4 (Mr Speaker's petition to the king at the delivery of the petition for billeting of soldiers). Also, 564, 'In our petition of right to the king's majesty. we mention...that no freeman ought to be compelled to suffer soldiers in his house.' Also, 566. Hume, n 4, vol 5, 25 'The soldiers were billeted upon private houses, contrary to custom, which required that, in all ordinary cases, they should be quartered in inns and public houses. Those who had refused or delayed the loan, were sure to be loaded with a great number of these dangerous and disorderly guests.' Also, 37.

${ }^{314}$ See McBain, n 140, 95-100. In the USA, the Quartering (Mutiny) Act of 1765 required the American colonies to supply food and accommodation to British troops. Opposition to it helped spark the American War in Independence. Congress prohibited billeting in the Third Amendment of the Bill of Rights. Constitution, art 3 'No soldier shall, in time of peace, be quartered in any house, without the consent of the owner; nor in time of war, but in a manner to be prescribed by law.' See also Blackstone, n 11, vol 1, 400 'And the petition of right enacts, that no soldier shall be quartered on the subject without his own consent.' See also 31 Car II c 1 (1679), s 32 'it shall and may be lawful for every... subject and inhabitant to refuse to sojourn or quarter any soldier or soldiers notwithstanding any command order or billeting whatever.' It also states 'by the laws and customs of the inhabitants cannot be compelled against their wills to receive soldiers into their houses and to sojourn them there.'

${ }^{315}$ See Clode, n 19, vol 1, 229-30 (suspended until 20 December 1689). It may be noted that Charles II (1660-85) continued to billet soldiers on private persons. Ibid, vol 1, 452 (billeting order of 6 April 1672). For the non-observance of the prohibition on billeting by James II (1685-8), ibid, 80-1

${ }^{316}$ Maitland, n 16, 452 'Billeting has been found necessary, and year by year the section about it in the Petition of Right is solemnly suspended'. Referring to the Mutiny Act of 1881 he also stated 'But the burden [of that Act] is not, I think, very heavy. Soldiers can only be billeted on those
} 
During the continuance in force of this Act, so much of any law as prohibits, restricts, or regulates the quartering or billeting of soldiers on any inhabitant of the UK without his consent is hereby suspended so far as such quartering or billeting is authorised by this Act. ${ }^{317}$

The unpleasantness to ordinary citizens of having soldiers billeted on them ended by 1688 since billeting was then restricted to inns etc. ${ }^{318}$

- Current legislation, the Army Act 1955, suspends the prohibition in the Petition of Right 1627 - although this is not strictly necessary since the Petition was designed to cover the billeting of 'soldiers' and 'mariners' on private citizens and the Army Act 1955 ( as well as the Air Force Act 1955) ${ }^{319}$ restricts billeting to inns etc. ${ }^{320}$ Similar powers are available to the naval authorities so long as the billeting provisions of the Army Act 1955 are in operation; ${ }^{321}$

- The provisions in the above Acts are of no effect until it appears to the Secretary of State for Defence that the public interest so requires and he makes an order directing that these provisions are to come into force. ${ }^{322}$ The provisions remain in force for only one month. However, they can be extended by a resolution of each House of Parliament that the same is required in the public interest. ${ }^{323}$

Thus, is the Crown prerogative to billet still required? One would argue not, for the following reasons:

- Legislation now covers the billeting of soldiers, sailors and air force personnel. Thus, the Crown prerogative has been superceded in respect of the first two - and it probably never applied to air force personnel in any case (the air force being only established in 1918, long after billeting was no longer utilised in practice); ${ }^{324}$

- The armed forces now occupy extensive military accommodation and so billeting is no longer required. If billeting were ever required in the future, the Secretary of State for Defence can rely on legislation although it is most unlikely inns and pubs would ever need to be availed of (or be of much use). Doubtless, these legislative provisions could be supplemented by emergency powers legislation, if required.

In conclusion, the Crown prerogative to billet members of the armed forces on the general public should be abolished. This would enable the repeal of the provision in the Petition of Right 1627 which prohibits the billeting of soldiers, or mariners, on citizens.

\section{Conclusions}

James I (1603-25) told the Commons, in a petition made to him in 1621, that:

\footnotetext{
whom, roughly speaking, one may call keepers of public houses - victualing houses is the statutory word. The prices to be paid for accommodation are fixed from time to time by parliament, and the act goes into detail; indeed it chronicles small beer, for not more than two pints thereof need be provided for any soldier per diem. So carriages, carts, horses may be impressed for the transport of regimental baggage, all to be practically paid for at parliamentary rates.'

317 The Army Act 1881 expired in 1956, being replaced by the Army Act 1955.

${ }^{318}$ See $n$ 310. See also Bruce, $n$ 4, 292. The Army Act 1881, s 104(2) 'Provided that an officer or soldier shall not be billeted - (a) in any private house.'

${ }^{319}$ Air Force Act 1955, ss 154-64.

${ }^{320}$ Army Act 1955, s 155(1) 'Billets...may be provided in pursuance of a billeting requisition (a) in any inn or hotel (whether licensed or not) or in any other premises occupied for the purposes of a business consisting of or including the provision of sleeping accommodation for reward; (b) in any building not falling within the last foregoing paragraph being a building to which the public habitually have access, whether on payment or otherwise, or which is wholly or partly provided or maintained out of rates; (c) in any dwelling, outhouse, warehouse, bar or stables; but not in any other premises.'

${ }^{321}$ Halsbury, n 13, vol 2(2), para 126. See also Armed Forces Act 1971, s 67(1). Halsbury notes 'The provisions relating to the billeting of the Royal Marines (who are subject to military law by the Army Act 1955, s 210(3) (as amended)... are also applicable to men of the reserve forces during such time as they attend training or are in permanent service or full-time service under a full-time service commitment. Reserve Forces Act 1996 s 123(1). Provision is also made in connection with the billeting of men of the reserve naval and marine forces: s 123(2).'

322 Army Act 1955 s 174(1) and Air Force Act 1955, s 174(1). See also Halsbury, n 13, vol 2(2), para 126, n 7.

${ }^{323}$ Army Act 1955, s 174(3), Air Force Act 1955, s 174(3). See also Halsbury, n 13, vol 2(2), para 126, n 9. For the billeting procedure see, para 127, for billeting offences, see para 128 and for the right to payment for billeting, see para 129.

${ }^{324}$ Can the Crown billet air force personnel on householders under the Crown prerogative? The Petition of Right only prohibits such billeting in the case of soldiers and mariners, thus, is it theoretically possible?
} 
In the body of your petition, you usurp upon our royal prerogative, and meddle with things far above your reach. $^{325}$

It is unlikely the Queen would use such words today. Rather, one suspects, like the House of Commons, ${ }^{326}$ she would welcome the modernisation of the law on the Crown prerogative as well as the abolition of obsolete ones. In this article the conclusion may be stated simply:

- The Crown prerogative to impose martial (military) law on civilians - whether in peace or war time should be abolished since: (a) exercise of the same in peacetime is illegal as result of the Petition of Right 1627 , s 8 (which section would be interpreted, today, to cover all riots and rebellions not amounting to civil war); (b) the exercise of the same is prohibited in war time unless the criminal courts are not open; (c) legislation now covers the field since - even in the case of (b), the Civil Contingencies Act 2004 (and earlier legislation, now repealed) provides for civil courts to be established to deal with criminal offences, and not military courts; (d) in any case, the purpose of subjecting civilians to military law - to impose the death penalty and harsher punishments - has gone, both having been abolished;

- The Crown prerogative to impress (ie. forcibly conscript) subjects into the army or navy should be abolished for the following reasons: (a) such a prerogative was dubious anyway; (b) impressing in the navy ended after 1814; (c) impressing in the army by virtue of prerogative - even it existed - ended before 1688 (it ended in 1780, when pursuant to legislation); (d) in both World Wars, legislation was used, rather than reliance on any Crown prerogative;

- The Crown prerogative to billet members of the armed forces on the public should be abolished, since legislation now covers the field.

\section{References}

Acland, R. (1921). The Naval Articles of War. Journal of Comparative Legislation and International Law, 3rd series, 3(4).

Adye, S. P. (1769). A Treatise on Courts Martial. New York: H Gaine.

Allen, J. (1849). Inquiry into the Rise and Growth of the Royal Prerogative in England. London: Longmans.

Anon. (1682). Abridgment of the English Military Discipline (rep by his Majesty's special command. The 1686 edition, printed by Charles Bell et al, London, has been reprinted by EEBO).

Anson, W. R. (1935). The Law and Custom of the Constitution. Oxford: Clarendon Press.

Archer, I. W. (1991). The Pursuit of Stability. Cambridge University Press. http://dx.doi.org/10.1017/CBO9780511522468

Bacon, M. (1798). New Abridgment of the Law (5th ed.). London.

Baker, J. (2003). The Oxford History of the Laws of England, 6. Oxford University Press.

Barendt, E. (1998). An Introduction to Constitutional Law. Oxford University Press.

Barrington, D. (1766). Observations on the Statutes (2nd ed.). London: W Bowyer.

Beadle, R., \& Hellinga, L. (2001). William Paston II and Pynson's Statutes of War (1492). Library, 2(2), 107-119. http://dx.doi.org/10.1093/library/2.2.107

Bellamy, J. G. (1970). The Law of Treason in England in the Later Middle Ages. Cambridge University Press. http://dx.doi.org/10.1017/CBO9780511522369

Bellamy, J. G. (1979). The Tudor Law of Treason. London: Routledge.

Blackstone, W. (1765-9). Commentaries on the Laws of England (1st ed.). Oxford: Clarendon Press.

Bowman, H. M. (1916). Martial Law and the English Constitution. Michigan Law Review, 15, 93-126. http://dx.doi.org/10.2307/1275130

Boynton, L. (1959). Billeting: The Example of the Isle of Wight. English Historical Review, 74, 23-40. http://dx.doi.org/10.1093/ehr/LXXIV.290.23

\footnotetext{
${ }^{325}$ Rushworth, $\mathrm{n} 25$, vol 1, 47. On another occasion in the same year James I told the Commons, 22 'And the lower house [ie. the House of Commons] is also to petition their king, and acquaint him with their grievances, and not to meddle with their king's prerogative.' See also $\mathrm{p} 55$. ${ }^{326}$ See $\mathrm{n} 2$.
} 
Boynton, L. (1962). The Tudor Provost Marshal. English Historical Review, 77, 437-455. http://dx.doi.org/10.1093/ehr/LXXVII.CCCIV.437

Boynton, L. (1964). Martial Law and the Petition of Rights. English Historical Review, 79, 255-284. http://dx.doi.org/10.1093/ehr/LXXIX.CCCXI.255

Bracton, H. (1968-1977). On the Law and Customs of England. Cambridge: Belknap Press of Harvard University Press.

Bradley, A. W., \& Ewing, K. D. (2006). Constitutional and Administrative Law (14th ed.). Longman.

Brand \& Nelson. (1867). Charge of the Lord Chief Justice of England to the Grand Jury at the Central Criminal Court in the case of the Queen against Nelson and Brand. London: William Ridgway

Brecknock, T. (1764). Droit Le Roy. London: W Grifffin.

Brewster, S. (1725). Jus Feciale Anglicanum or a Treatise of the Laws of England relating to War and Rebellion. London.

Brodie, G. (1866). Constitutional History. London: Longmans.

Brooke, R. (1586). La Graunde Abridgment. London: Tottell.

Bruce, A. (1717). The Institutions of Military Law. Edinburgh.

Bryant, J. (1824). Account of the Insurrection of the Negro Slaves in the Colony of Demerara which broke out on 18 August 1823. Georgetown, Demerara.

Burn, R. (1799). Digest of the Militia Laws. London: printed for W Strahan and T Cadell.

Butler, C. (1777). An Essay on the Legality of Impressing Seamen (1st ed.). London: printed for T Cadell.

Campbell, C. (1994). Emergency Law in Ireland 1918-1925. Oxford: Clarendon Press.

Capua, J. V. (1977). The Early History of Martial Law in England from the Fourteenth Century to the Petition of Right. Cambridge Law Journal, 36, 152-173. http://dx.doi.org/10.1017/S0008197300014409

Carter, A. T. (1944). A History of the English Courts (7th ed.). Butterworth.

Charge of the Lord Chief Justice of England to the Grand Jury at the Central Criminal Court in the case of the Queen against Nelson and Brand. (1867). London: William Ridgway.

Chitty Jun, J. (1820). A Treatise of the Law of the Prerogatives of the Crown. London: Butterworths.

Clark D., \& McCoy, G. (2000). The Most Fundamental Legal Right. Oxford University Press. http://dx.doi.org/10.1093/acprof:oso/9780198265849.001.0001

Clode, C. M. (1869). The Military Forces of the Crown. London: John Murray.

Clode, C. M. (1872). The Administration of Justice under Military and Martial Law (2nd ed.). London: John Murray.

Cobbett, W. (1812). Parliamentary History. London: TC Hansard.

Coke, E. (1824). Institutes of the Laws of England. London: W Clarke \& Sons.

Comyns, J. (1822). Digest of the Laws of England.

Cook, C. (1918). Defence of the Realm Manual. Her Majesty's Stationary Office.

Corwin, E. S. (1932). Martial Law, Yesterday and Today. Political Science Quarterly, 47(1), 95-104. http://dx.doi.org/10.2307/2142704

Curry, A. (2008). The Military Ordinances of Henry V: Texts and Contexts. In C. G. Wilson (Ed.), War, Government and Aristocracy in the British Isles c 1150-1500: Essays in Honour of Michael Prestwich. Woodbridge, UK, Boydell.

Da Costa, E. V. (1994). Crowns of Glory: Tears of Blood: The Demerara Slave Rebellion of 1823. Oxford University Press.

De Smith, S. A., \& Brazier, R. (1998). Constitutional and Administrative Law (8th ed.). Penguin.

Dennison, G. M. (1974). Martial Law: The Development of a Theory of Emergency Powers 1776-1861. American Journal of Legal History, 18, 52-79. http://dx.doi.org/10.2307/845241

Dicey A. V. (2007). A Leap in the Dark. Echo Library. 
Dicey, A. V. (1948). Introduction to the Study of the Law of the Constitution (9th ed.). Macmillan.

Dobson, R. B. (1970). The Peasant's Revolt of 1381. Macmillan.

Dodd, C. (1902). The Case of Marais. Law Quarterly Review, 18, 143-151.

Donaghan, B. (2008). War in England 1642-1649. Oxford University Press. http://dx.doi.org/10.1093/acprof:oso/9780199285181.001.0001

Dunn, A. (2004). The Peasants' Revolt. Tempus.

Earle, R. H. (1902). Martial Law. Law Quarterly Review, 18, 133-142.

Ewing, K. D., \& Gearty, C. A. (2000). The Struggle for Civil Liberties. Oxford University Press.

Fairman, C. (1943). The Law of Martial Rule. Chicago.

Finlason, W. F. (1866). A Treatise of Martial Law. London: Stevens \& Sons.

Finlason, W. F. (1867). Commentaries upon Martial Law. London: Stevens \& Son.

Fitzherbert, A. (1577). La Graunde Abridgment (3rd ed.). London: Tottell.

Forsyth, W. (1869). Cases and Opinions on Constitutional Law. London: Stevens \& Haynes.

Glanvil. (1189). Treatise on the Laws and Customs of the Realm. Oxford University Press.

Grazebrook, G. (1895). The Earl Marshall's Court in England. Liverpool.

Greenwood, F. M., \& Wright, B. (2002). Rebellion and Invasion in the Canadas 1837-1839. Canadian State Trials, 2. Toronto: The Osgoode Society and the University of Toronto Press.

Gross, O., \& Aolain, F. (2006). Law in Times of Crisis. Cambridge University Press. http://dx.doi.org/10.1017/CBO9780511493997

Hale, M. (1736). The History of the Pleas of the Crown. London: E \& R Nutt \& R Gosling.

Hale, M. (1820). History and Analysis of the Common Law of England.

Hale, M. (1971). The History of the Common Law of England. Univ. of Chicago Press.

Hale, Sir Matthew Hale's Prerogatives of the King. (1976). Selden Society, 92.

Hallam, H. (1897). The Constitutional History of England. London: J Murray.

Halsbury. Laws of England (4th ed. with updates).

Halsbury. Statutes of England (4th ed. with updates).

Hardesty, J. (1718). Militia Law. London: E Nutt \& R Gosling.

Harford, R. (1680). English Military Discipline (EEBO ed.).

Hargrave, F. (1811). Jurisconsult Exercitations. W Clarke: Lincoln's Inn.

Hawkins, W. (1739). A Treatise of the Pleas of the Crown (3rd ed.). London: printed in the Savoy.

Hawtin, W. G. (1917-8). Law and Practice of Military Conscription under Military Service Acts 1916-18.

Hay, E. (1803). History of the Insurrection in Wexford in 1798. Dublin.

Heuman, G. (1994). The Killing Time: The Morant Bay Rebellion in Jamaica. University of Tennnesse Press.

Heuston, R. F. V. (1964). Essays in Constitutional Law (2nd ed.). London: Stevens \& Sons.

Holdsworth, W. (1902). Martial Law Historically Considered. Law Quarterly Review, 18, 117-132.

Holdsworth, W. (2009). A History of English Law. Sweet \& Maxwel.

Hood P. O. \& Jackson. (2001). Constitutional and Administrative Law (8th ed.). Sweet \& Maxwell.

House of Commons. (2004). Public Administration Select Committee. $4^{\text {th }}$ Report of Session 2003-4. Taming the Prerogative: Strengthening Ministerial Accountability to Parliament. HC 422 (published 16 March 2004).

Hughes, P. L., \& Larkin, J. F. (1969). Tudor Royal Proclamations. New Haven \& London: Yale University Press.

Hughes, W. (1660-3). Grand Abridgment of the Law. London.

Hume, D. (1884). The History of England. London: Frederick Warne \& Co.

Jennings, I. (1959). The Law and the Constitution (5th ed.). University of London Press. 
Jolliffe, J. E. A. (1948). Constitutional History of Medieval England. A \& C Black.

Jones, J. (1969). Whitehall Diary. Oxford University Press.

Kaufman, A. L. (2009). The Historical Literature of the Jack Cade Rebellion. Ashgate Publishing.

Lilley, J. (1765). Practical Register (2nd ed.).

Loades, D. (2001). The Wyatt Rebellion. Oxford: The Davenant Press.

Lyle, H. M. (1950). The Rebellion of Jack Cade. Historical Association.

Madden, R. R. (1857-60). The United Irishmen (2nd ed.).

Maitland, F. W. (1963). The Constitutional History of England. Cambridge University Press.

Manning, R. (2006). An Apprenticeship in Arms: The Origins of the British Army 1585-1702. Oxford University Press.

Marshall, G. (1971). Constitutional Theory. Oxford: Clarendon Press.

Mc Glynn, M. (2003). The Royal Prerogative and the Learning of the Inns of Court. Cambridge University Press. http://dx.doi.org/10.1017/CBO9780511495427

McBain, G. S. (2007a). Abolishing the Crime of Treason Felony. Australian Law Journal, 81, 812-838.

McBain, G. S. (2007b). Abolishing the Crime of Treason. Australian Law Journal, 81. 94-134.

McBain, G. S. (2010). Modernising the Monarchy in Legal Terms. King's Law Journal, 21, 535-560. http://dx.doi.org/10.5235/096157610793391517

McBain, G. S. (2011a). Abolishing Obsolete Crown Prerogatives relating to the Military. Nottingham Law Journal, 20, 14-37.

McBain, G. S. (2011b). Abolishing 'High Crimes and Misdemeanours' and the Criminal Processes of Impeachment and Attainder. Australian Law Journal, 85, 810-879.

McBain, G. S. (2011c). Modernising the Monarchy in Legal Terms: Part 2. King's Law Journal, 22, 95-118.

Mills, L. A. (1964). Ceylon under British Rule 1795-1932. Frank Cass \& Co.

Nelson, W. (1725-6). Abridgment of the Common Law. London: E \& R Nutt \& R Gosling.

Noyes, A. H. (1930). The Military Obligation in Medieval England. Ohio State University.

Oxford Dictionary of National Biography (ODNB).

Phillips, O. H., \& Jackson, P. (2001). Constitutional and Administrative Law (8th ed.). Sweet \& Maxwell.

Plowden, F. (1806). An Historical Review of the State of Ireland. Philadelphia.

Pollock, F. (1902). What is Martial Law? Law Quarterly Review, 18, 152-158.

Report of the Committee appointed to Inquire into the Circumstances connected with the Disturbances at the Featherstone on the 7th September, 1893.

Report of the Inquiry into the Export of Defence Equipment and Dual - Use Goods to Iraq and Related Prosecutions. (1995). House of Commons Paper, 6(115).

Riley, H. T. (1868). Memorials of London and London Life. London: Longmans.

Robertson, C. H. (1935). Select Statutes Cases and Documents (6th ed.). Methuen \& Co.

Rolle, H. (1688). Abridgment des plusieurs Cases et Resolutions del Common Ley.

Rolls of Parliament (RP) (on CD, SDE editions).

Rushworth, J. (1721). Historical Collections of Private Passages of State, Weighty Matters in Law, Remarkable Proceedings in Five Parliaments (printed by JA for Robert Boulter).

Rymer, T. (1727-35). Foedera.

Samuel, E. (1816). An Historical Account of the British Army. London: William Clowes.

Schull, J. (1971). Rebellion: The Rising in French Canada 1837. Toronto: Macmillan.

Scott, H. L. (1968). Military Dictionary. New York: Greenwood Press.

Sheppard, W. (1675). Grand Abridgment of the Common and Statute Law of England. London. 
Smith, T. (1562-5). De Republica Anglorum. Cambridge University Press.

Squibb, G. D. (1953). The Law of Arms in England. Heraldry Society.

Statham, N. (c.1495). Abridgment of the Law. London: Pynson.

Staunford, W. (1607). An Exposition of the King's Prerogative (2nd ed.). Company of Stationers.

Stephen, J. F. (1883). A History of the Criminal Law of England. Macmillan \& Co.

Strype, J. (1822). Ecclesiastical Memorials. Oxford: Clarendon Press.

Stubbs, W. (1874). The Constitutional History of England (1st ed.). Oxford: Clarendon Press.

Sullivan, R. J. (1779). Thoughts on Martial Law. London: T Becket.

Sutcliffe, M. (1593). Practice, Proceedings and Lawes of Armes.

Sweet \& Maxwell. (1955). A Legal Bibliography of the British Commonwealth of Nations. Sweet \& Maxwell.

Taswell - Langmead, P. (1960). English Constitutional History (11th ed.). Sweet \& Maxwell.

Thornton, G. (2010). The Rising in the North: The Rising of the Northern Earls. Ergo Press.

Twiss, T. (1871). The Black Book of the Admiralty. London: RS.

Tytler, A. F. (1806). An Essay on Military Law (2nd ed.). London: T Egerton.

Viner, E. (1741-57). A General Abridgment of the Law and Equity (1st ed.). London: GGJ and J Robinson.

Walker, P. M. (1980). Oxford Companion to the Law. Oxford University Press.

Wilkinson, B. (1958). Constitutional History of Medieval England. Longmans.

Wormuth, F. D. (1939). The Royal Prerogative 1603-1648. Cornell University Press. 